\title{
Effects of Rumen-protected Methionine, Choline and Betaine on Dairy Cattle Health and Performance
}

\author{
Yu Zang
}

Follow this and additional works at: https://researchrepository.wvu.edu/etd

\section{Recommended Citation}

Zang, Yu, "Effects of Rumen-protected Methionine, Choline and Betaine on Dairy Cattle Health and Performance" (2016). Graduate Theses, Dissertations, and Problem Reports. 7026.

https://researchrepository.wvu.edu/etd/7026

This Thesis is protected by copyright and/or related rights. It has been brought to you by the The Research Repository @ WVU with permission from the rights-holder(s). You are free to use this Thesis in any way that is permitted by the copyright and related rights legislation that applies to your use. For other uses you must obtain permission from the rights-holder(s) directly, unless additional rights are indicated by a Creative Commons license in the record and/ or on the work itself. This Thesis has been accepted for inclusion in WVU Graduate Theses, Dissertations, and Problem Reports collection by an authorized administrator of The Research Repository @ WVU. For more information, please contact researchrepository@mail.wvu.edu. 
Effects of Rumen-protected Methionine, Choline and Betaine on Dairy Cattle Health and Performance

\title{
Yu Zang
}

\author{
Thesis submitted \\ to the Davis College \\ at West Virginia University
}

In partial fulfillment of the requirements for the degree of

Master of Science in

Nutritional \& Food Sciences

Joseph W. McFadden, Ph.D.

K. Marie Krause, Ph.D.

Eugene E. Felton, Ph.D.

Division of Animal and Nutritional Sciences

Morgantown, West Virginia

2016

Keywords: betaine, choline, dairy cow, methionine

Copyright 2016 Yu Zang 


\author{
ABSTRCT \\ Effects of Rumen-protected Methionine, Choline and Betaine on \\ Dairy Cattle Health and Performance
}

Yu Zang

Dairy cows experience extensive lipid mobilization in adipose tissue during the transition from gestation to lactation. A high amount of circulating non-esterified fatty acid (NEFA) results in fatty liver that is associated with reduced milk production (Duffield et al., 2009), metabolic diseases (Hammon et al., 2006), and decreased reproductive performance (Walsh et al., 2007). The function of VLDL is to export TAG from liver. Previous work suggested that micronutrients supplemented may elevated VLDL export. Choline has been shown to increase milk production and milk fat yield (Erdman et al., 1991) and decrease triacylglycerol (TAG) in the liver (Pomfret et al., 1990). Emmanuel et al. (1984) suggested that $28 \%$ of absorbed methionine (Met) is used for the synthesis of choline. Also, Met is the first limiting amino acid (AA) for milk protein synthesis of dairy cattle (NRC, 2001) and involved into synthesis of very low-density lipoprotein (VLDL). Furthermore, betaine is a methyl donor that recycles homocysteine to Met after Met is utilized to synthesize phospholipids within VLDL. The set of studies in this master thesis evaluated the effects of Met, choline and betaine on dairy cattle health and performance. In the first experiment, thirty multiparous Holstein cows independently housed were fed total mixed rations (TMR) with or without micronutrients ( $22 \mathrm{~g} / \mathrm{d}$ Met, $10 \mathrm{~g} / \mathrm{d}$ choline chloride, $3 \mathrm{~g} / \mathrm{d}$ betaine) from $-28 \mathrm{~d}$ prepartum to d 14 postpartum. All cows received $65 \mathrm{~g} / \mathrm{d}$ of lipid encapsulate with $62 \%$ palmitic acid. Blood and liver samples were collected routinely prepartum and postpartum. Milk yields were recorded, milk samples were collected and milk components were measured after calving. Plasma circulating non-esterified fatty acids (NEFA), $\beta$-hydroxybutyrate (BHBA), glucose, insulin, TAG, total cholesterol, free cholesterol, cholesterol ester, VLDL, and lowdensity lipoprotein (LDL), and serum total protein, albumin, globulin, hemoglobin, and AA concentrations were measured. Micronutrient supplementation had the tendency to improve milk total solids (TS) percentage $(P=0.11)$ and had significantly elevated the levels of serum Met at $\mathrm{d}$ 10 and $12(P<0.05)$, relative to no supplementation. Similarly, the ratio of lysine (Lys) to Met in cows with micronutrient supplementation was significantly lower than cows without supplementation $(P<0.05)$. No others treatment effects were observed for metabolites in blood and milk. In the second experiment, twelve multiparous Holstein cows $(602 \pm 46 \mathrm{~kg}$ body weight (BW), $174 \pm 18$ day in milk (DIM)) were used in a replicated $4 \times 4$ Latin square design with 21 $\mathrm{d}$ treatment periods. Dietary treatments included a corn silage and alfalfa haylage-based diet (control; no added Met) supplemented with one of three rumen protected (RP) Met sources (Novimet (Innovad), Smartamine M (Adisseo), and Mepron M85 (Evonik)). Treatments were designed to maintain a Lys:Met ratio of 2.9:1. For control, Lys (RP-Lys; AjiPro) was added at $0.025 \%$ ration DM. For RP-Met supplementation, Met (RP-Met) was added at $0.03 \%$ ration DM. Cows fed RP-Met were provided Lys (RP-Lys) at $0.20 \%$ ration DM. Milk yields were recorded, and samples were collected during each period (d 19 to 21). Blood samples were collected on d 21 at 2, 4, and $6 \mathrm{~h}$ following feeding. Milk protein content was elevated with Smartamine M, relative to control or Novimet $(3.30 \%$ vs. $3.24 \%$, and $3.24 \%$ respectively; $P<0.05)$. There was a tendency for milk urea nitrogen (MUN) to be modified by treatments. Smartamine M increased serum Met concentration $(27.3 \mu \mathrm{M})$ as compared with control $(21.2 \mu \mathrm{M})$, Novimet $(22.7 \mu \mathrm{M})$, or 
Mepron M85 $(23.3 \mu \mathrm{M})(P<0.001)$. In a similar manner, Smartamine M lowered the serum Lys:Met ratio (4.5:1) as compared with control (5.2:1), Novimet (5.2:1), or Mepron M85 (5.1:1) $(P<0.05)$. Treatments did not modify other milk components and the serum levels of all other AA including Lys. Taken together, results in our studies demonstrate that RP-Met supplementation can increase circulating Met supply and milk protein percentage; however, addition of RP-Met (22 g/d), choline (10 g/d) and betaine ( $3 \mathrm{~g} / \mathrm{d}$ ) did not show obvious effects on milk production performance and health of dairy cows. 


\section{ACKNOWLEDGEMENTS}

I would like to thank Dr. Joseph W. McFadden for the opportunity to conduct dairy science research in his laboratory and his guidance throughout my Master's program at West Virginia University. The experiences that Dr. McFadden has provided me are crucial for the development of my abilities as a scientific researcher. I will never forget the help and support from Dr. McFadden over the last two years.

Second, I want to thank Dr. K. Marie Krause for the opportunity to work in her lab. Her patience and kindness provided me a relaxed environment to learn and explore knowledge. Thank you Dr. Eugene E. Felton for serving on my graduate advisory committee and providing me with valuable advice for current and future work.

Third, I would like to thank all the members of the McFadden lab: Sina Saed Samii, Dr. Eduardo Rico, Alice Mathews, Amanda Davis, and Zachary Phipps. Their friendship, support, and teamwork have helped me greatly at WVU. The memories created with them are enjoyable and will be remembered forever.

Additionally, I acknowledge all the members of Van Gilder family at Dovan Farms for their help and kindness during those four months in 2015 summer. I thank the staff members at WVU animal science farm for their personal help, as well as their technical support. A special thanks to Will McClung, Fred Roe, George Bolyard, Greg Kurilla, and Curtis Swiantek, who were helpful in several aspects.

Lastly, my appreciation goes to my families include my grandma, father, mother, uncle, aunt, brother, sister in law, and Wei Jiang. I made full use of these two years with their help and understanding. 


\section{TABLE OF CONTENTS}

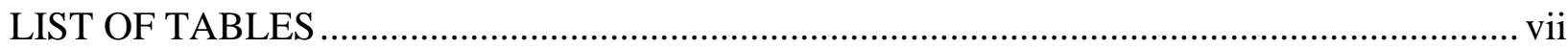

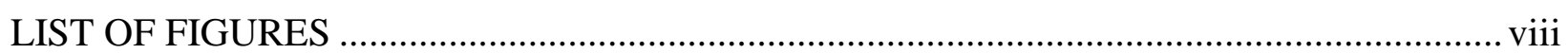

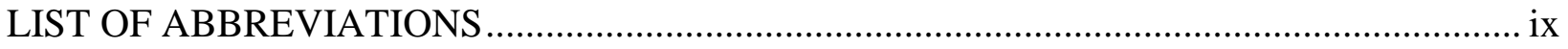

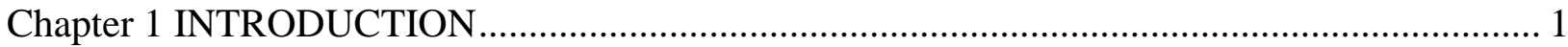

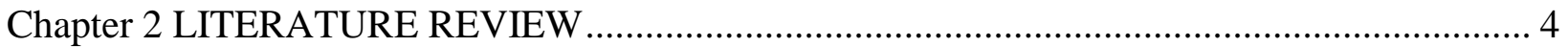

Protein nutrition in dairy cattle ...................................................................................... 4

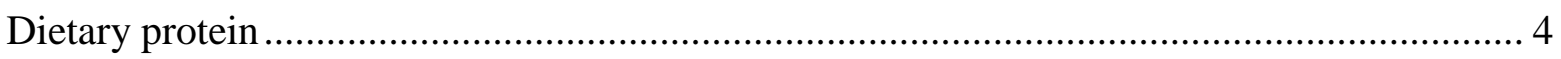

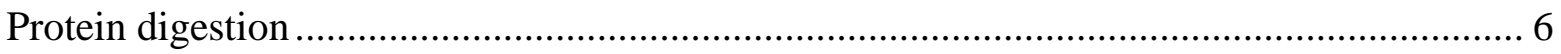

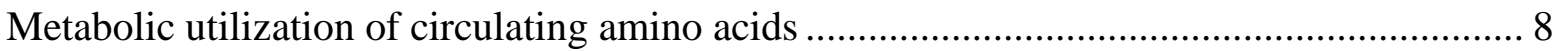

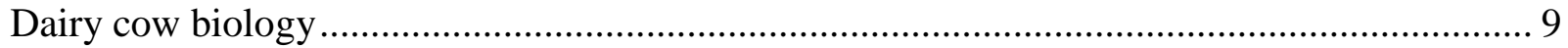

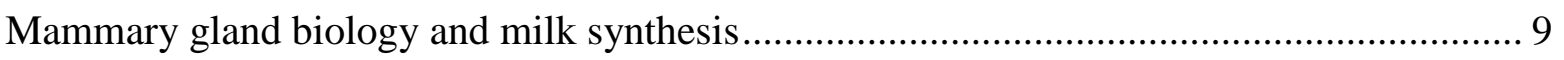

Negative energy balance in peripartal dairy cows ........................................................... 11

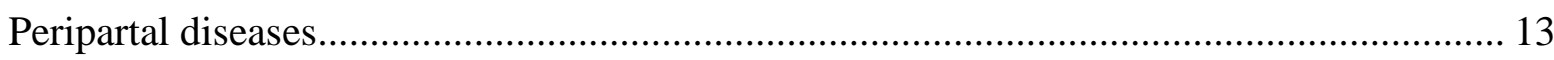

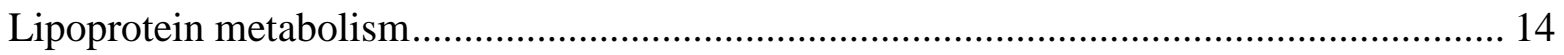

Micronutrient supplementation in dairy cows................................................................... 16

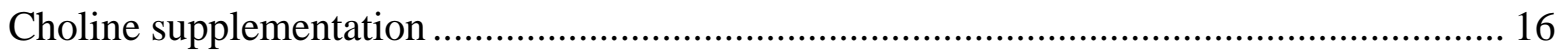

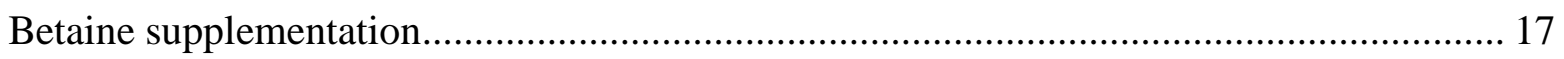

Methionine and lysine supplementation ........................................................................ 17

Chapter 3 EFFECTS OF RUMEN-PROTECTED METHIONINE, CHOLINE, AND BETAINE ON PERIPARTURIENT DAIRY CATTLE HEALTH AND MILK PRODUCTION................. 27

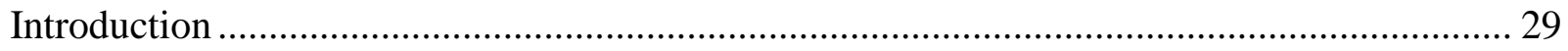

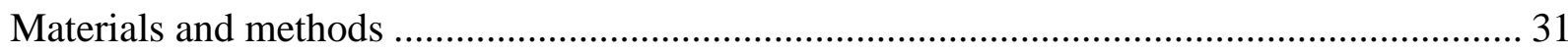

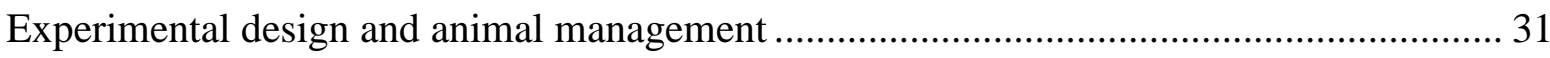

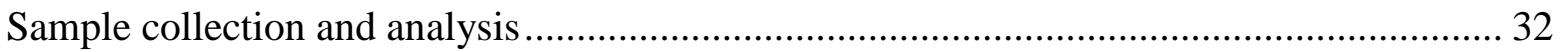

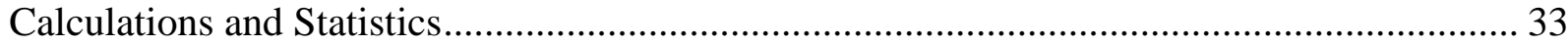

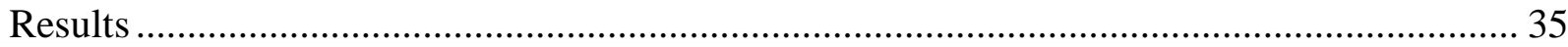

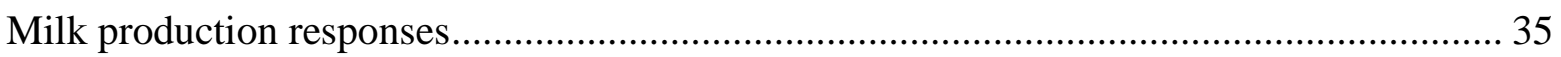

Dry matter intake, body condition score, and body weight .............................................. 36

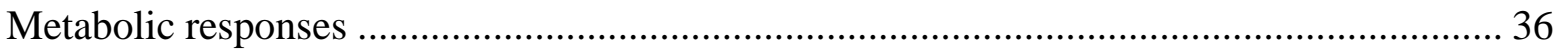

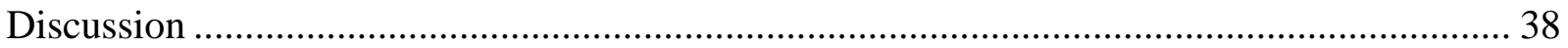

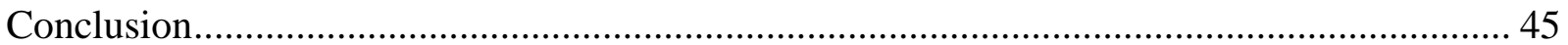




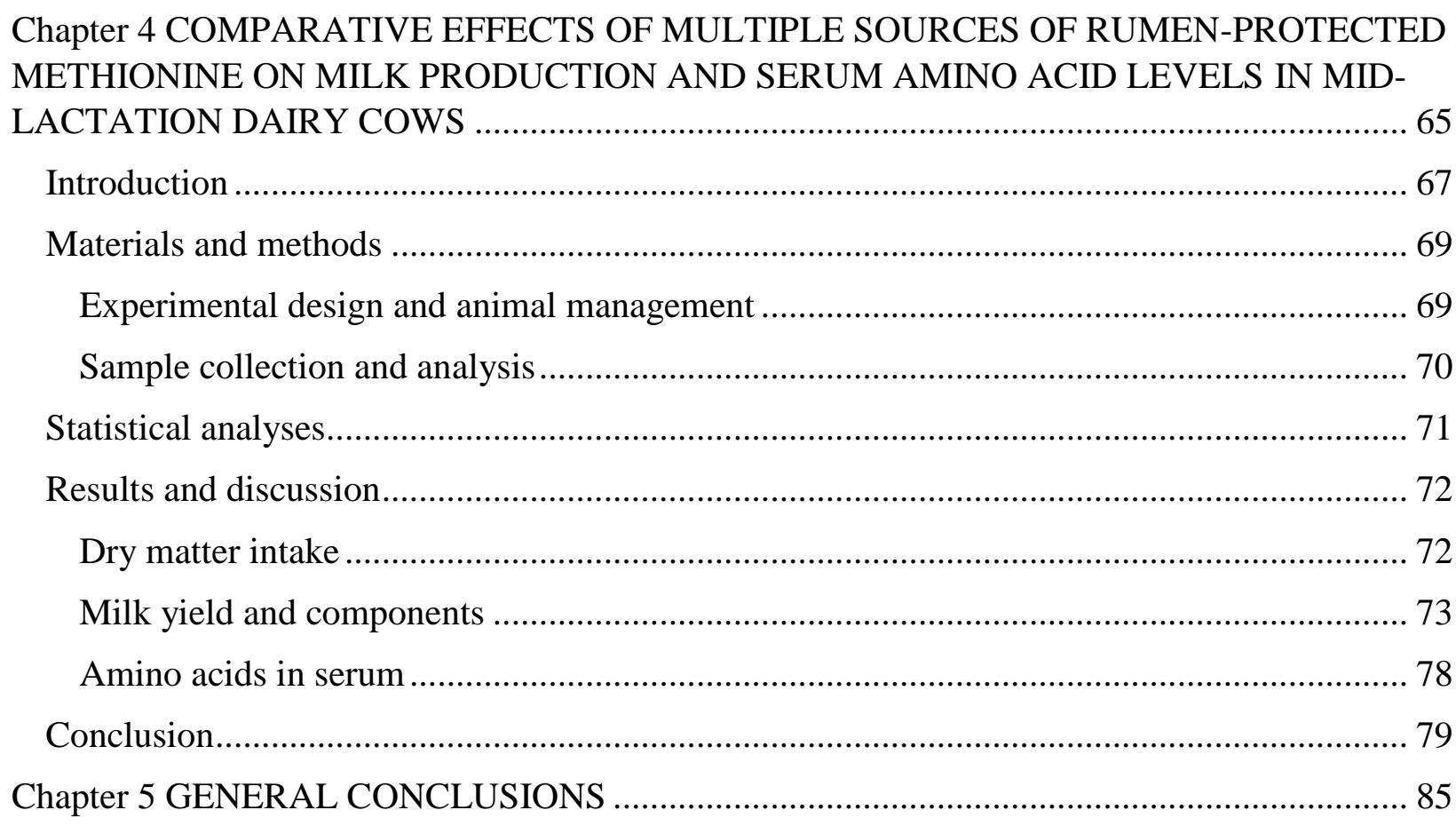




\section{LIST OF TABLES}

Table 3-1: Ingredients and nutrient composition of experimental diets supplemented with or without micronutrient (rumen-protected methionine, choline and betaine) supplementation...... 49 Table 3-2: Serum amino acid responses to micronutrient supplementation (rumen-protected methionine, choline and betaine)

Table 4-1: Ingredients and nutrient composition of the control diet for mid-lactation dairy cows

Table 4-2: Dry matter intakes and production responses to rumen-protected methionine and lysine supplementation......

Table 4-3: Serum amino acid concentration responses to rumen-protected methionine and lysine

supplementation 84 


\section{LIST OF FIGURES}

Figure 3-1: Milk yield responses to diets with or without micronutrient supplementation in the first two months of lactation.

Figure 3-2: Milk composition responses to diets with or without micronutrient supplementation in the first month of lactation. 55

Figure 3-3: Dry matter intake responses to diets with or without micronutrient supplementation across the experiment. 56

Figure 3-4: Body condition score and body weight patterns of dairy cows in the transition period.

Figure 3-5: Plasma metabolites responses in periparturient dairy cows to diets with or without micronutrient supplementation.

Figure 3-6: Plasma metabolites responses in periparturient dairy cows to diets with or without micronutrient supplementation

Figure 3-7: Serum protein metabolites responses in dairy cows to diets with or without micronutrient supplementation postpartum .....

Figure 3-8: Liver lipid percentages in periparturient dairy cows to diets with or without micronutrient supplementation. 


\section{LIST OF ABBREVIATIONS}

\begin{tabular}{|c|c|}
\hline AA & Amino acid(s) \\
\hline ADF & Acid detergent fiber \\
\hline Ala & Alanine \\
\hline Apo & Apoprotein \\
\hline Asp & Aspartic acid \\
\hline ATP & Adenosine triphosphate \\
\hline BCAA & Branched-chain amino acids \\
\hline BCS & Body condition score \\
\hline BHBA & $\beta$-hydroxybutyrate \\
\hline BW & Body weight \\
\hline $\mathrm{CM}$ & Chylomicrons \\
\hline CNCPS & Cornell net carbohydrate protein system \\
\hline $\mathrm{CO}_{2}$ & Carbon dioxide \\
\hline $\mathrm{CoA}$ & Coenzyme A \\
\hline $\mathrm{CP}$ & Crude protein \\
\hline $\mathrm{CV}$ & Coefficient of variation \\
\hline Cys & Cysteine \\
\hline DIM & Day in milk \\
\hline DM & Dry matter \\
\hline DMI & Dry matter intake \\
\hline EAA & Essential amino acids \\
\hline $\mathrm{ECM}$ & Energy-corrected milk \\
\hline ELISA & Enzyme-linked immunosorbent assay \\
\hline
\end{tabular}




$\begin{array}{ll}\text { FA } & \text { Fatty acid(s) } \\ \text { FCM } & \text { Fat-corrected milk } \\ \text { GC/MS } & \text { Gas chromatography mass spectrometry } \\ \text { Gln } & \text { Glutamine } \\ \text { Glu } & \text { Glutamate } \\ \text { His } & \text { Histidine } \\ \text { Ile } & \text { Isoleucine } \\ \text { LDL } & \text { Low-density lipoprotein } \\ \text { Leu } & \text { Leucine } \\ \text { Lys } & \text { Lysine } \\ \text { Met } & \text { Methionine } \\ \text { MP } & \text { Metabolizable protein } \\ \text { MTTP } & \text { Microsomal triacylglycerol transfer protein } \\ \text { MUN } & \text { Milk urea nitrogen } \\ \text { NDF } & \text { Neutral detergent fiber } \\ \text { NEAA } & \text { Non-essential amino acids } \\ \text { NEB } & \text { Negative energy balance } \\ \text { NEFA } & \text { Non-esterified fatty acids } \\ \text { NPN } & \text { Non-protein nitrogen } \\ \text { PC } & \text { Phosphatidylcholine } \\ \text { RDe } & \text { Phenylalanine } \\ \text { Q-TOF } & \text { Qudrupole-time of flight } \\ \text { RDP } & \text { Rumen-degradable protein } \\ \text { N } & \end{array}$




$\begin{array}{ll}\text { RP } & \text { Rumen-protected } \\ \text { RU } & \text { Rumen-unprotected } \\ \text { RUP } & \text { Rumen-undegradable protein } \\ \text { SCC } & \text { Somatic cell count } \\ \text { TAG } & \text { Triacylglycerol } \\ \text { TCA } & \text { Trichloroacetic acetic } \\ \text { TMR } & \text { Total mixed ration } \\ \text { Trp } & \text { Tryptophan } \\ \text { TS } & \text { Total solids } \\ \text { Tyr } & \text { Tyrosine } \\ \text { Val } & \text { Valine } \\ \text { VFA } & \text { Volatile fatty aicds } \\ \text { VLDL } & \text { Very low-density lipoprotein } \\ \text { WVU } & \text { West Virginia university }\end{array}$




\section{Chapter 1}

\section{INTRODUCTION}

Dairy cows transitioning from gestation to lactation experience negative energy balance (NEB) due to reduced energy intake and increased energy demand. To adapt to metabolic stress, cows mobilize adipose tissue hydrolyzing triacylglycerol (TAG) into non-esterified fatty acid (NEFA) and glycerol. In turn, increased circulating NEFA enters liver tissue which can then be re-esterified into TAG or oxidized to adenosine triphosphate (ATP), and carbon dioxide $\left(\mathrm{CO}_{2}\right)$ or ketones. In comparison to monogastric animals, ruminants have limited capability to export hepatic TAG by synthesizing very low-density lipoprotein (VLDL) (Kleppe et al., 1988). As a detriment, the accumulation of liver lipid is associated with reduced milk production (Duffield et al., 2009), metabolic diseases (Hammon et al., 2006), and decreased reproductive performance (Walsh et al., 2007).

One potential industry approach to alleviate liver fat accumulation during the transition period is the supplementation of micronutrients including methionine (Met), choline, or betaine. Choline can be used to synthesize phosphatidylcholine (PC) within VLDL directly. One study by Emmanuel et al. (1984) suggested that $28 \%$ of absorbed Met is used for the synthesis of choline. In addition, betaine is a methyl donor that recycles homocysteine to Met used in the synthesis of PC from phosphatidylethanolamine (PE). Previous studies have observed that the addition of individual micronutrients mentioned above improve milk production performance and health condition in periparturient dairy cows (Osorio et al., 2013; Piepenbrink and Overton, 2003; Wang et al., 2010).

Both milk yield and milk protein production decline after early lactation. In corn silagebased diets, Met is the first limiting amino acid (AA) for milk protein synthesis of dairy cattle 
(NRC, 2001). Supplementing rumen-protected (RP)-Met into mid-lactation dairy cow diets may improve Met availability to obtain greater milk protein synthesis. To explore better feeding managements for dairy producers, the objective of this Masters research is to evaluate the effects of micronutrient supplementation on dairy cattle health and performance. 


\section{Literature Cited}

Duffield, T. F., K. D. Lissemore, B. W. McBride, and K. E. Leslie. 2009. Impact of hyperketonemia in early lactation dairy cows on health and production. J. Dairy Sci. 92:571-580.

Emmanuel, B., and J. J. Kennelly. 1984. Kinetics of methionine and choline and their incorporation into plasma lipids and milk components in lactating goats. J. Dairy Sci. 63:1912-1918.

Erdman, R. A. and B. K. Sharma. 1991. Effect of dietary rumen-protected choline in lactating dairy cows. J. Dairy Sci. 74:1641-1647.

Hammon, D. S., I. M. Evjen, T. R. Dhiman, J. P. Goff, and J. L. Walters. 2006. Neutrophil function and energy status in Holstein cows with uterine health disorders. Vet. Immunol. N. Immunopathol. 113:21-29.

Kleppe, B. B., R. J. Aiello, R. R. Grummer, and L. E. Armentano. 1988. Triglyceride accumulation and very low density lipoprotein secretion by rat and goat hepatocytes in vitro. J. Dairy Sci. 71:1813-1822.

NRC. 2001. Nutrient Requirements of Dairy Cattle. 7th rev. ed. Natl. Acad. Sci., Washington, DC.

Osorio, J. S., P. Ji, J. K. Drackley, D. Luchini, and J. J. Loor. 2013. Supplemental Smartamine M or MetaSmart during the transition period benefit postpartal cow performance and blood neutrophil function. J. Dairy Sci. 96:1-16.

Piepenbrink, M. S. and T. R. Overton. 2003. Liver metabolism and production of cows fed increasing amounts of rumen-protected choline during the periparturient period. J. Dairy Sci. 86:1722-1733.

Pomfret, E. A. and S. H. Zeisel. 1990. Effects of choline deficiency and methotrexate treatment upon rat liver. J. Nutr. Biochem. 1:533-541.

Walsh, R. B., J. S. Walton, D. F. Kelton, S. J. LeBlanc, K. E. Leslie, and T. F. Duffield. 2007. The effect of subclinical ketosis in early lactation on reproductive performance of postpartum dairy cows. J. Dairy Sci. 90:2788-2796.

Wang, C., Q. Liu, W. Z. Yang, J. Wu, W. W. Zhang, P. Zhang, K. H. Dong, and Y. X. Huang. 2010. Effects of betaine supplementation on rumen fermentation, lactation performance, feed digestibilities and plasma characteristics in dairy cows. J. Agric. Sci. 148:487-495. 


\section{Chapter 2}

\section{LITERATURE REVIEW}

\section{Protein nutrition in dairy cattle}

Dietary protein for ruminant animals includes protein and non-protein nitrogen (NPN), levels of which are widely varied in feedstuffs (NRC, 2001). The requirement for dietary protein is determined by breed, body weight (BW), lactation period, and milk yield and components. Usually, the protein requirement for early lactation cows is higher than mid or late lactation cows. Specifically, the dietary protein recommendation for early, mid, and late-lactation dairy cows is $17-19 \%, 15-17 \%$, and 13-15\% of ration dry matter (DM), respectively (NRC, 2001).

\section{Dietary protein}

Dairy cows consume protein in feedstuffs as crude protein $(\mathrm{CP})$ including rumendegradable protein (RDP) and rumen-undegradable protein (RUP) to supply amino acids (AA) for maintenance, growth, reproduction and milk production. In the rumen of a dairy cow, RDP is digested by microorganisms to produce microbial protein, and RUP can escape ruminal degradation. Microbial protein, RUP, and endogenous protein contribute to the supply of AA that pass to the small intestine (Clark et al., 1992). Ruminally synthesized microbial protein typically supplies most of the AA absorbed by the small intestine, and RUP is the second most important source of AA for dairy cows (NRC, 2001). In addition, the quality of microbial protein is better than RUP because the profile of AA is more consistent and more similar to the AA composition of milk. Research has demonstrated that the intestinal digestibility of freeze-dried rumen microbes ranges from 74 to $80 \%$ (Abdo et al., 1964), whereas intestinal digestibility of RUP 
exhibits larger variability ranging from 37.8 for hay to $98 \%$ for soybean meal (Erasmus et al., 1994).

To better understand degradation and ruminal escape of feed proteins, two methods are usually applied to divide CP into fractions (Sniffen et al., 1992). The most often used model divides feed CP into three fractions: A, B, and C according to ruminal protein degradation. Fraction A represents CP that is degradable completely in the rumen including NPN assumed to be degraded instantly and a small amount of true protein due to a high solubility or a very small particle size (NRC, 2001). Fraction C refers to CP that is completely undegradable in the rumen (NRC, 2001). Fraction B is the remaining portion of the CP and includes the proteins that are potentially degradable in the rumen based on the passage rate (NRC, 2001). A more complex model was developed by Cornell University, the Cornell Net Carbohydrate Protein System (CNCPS) (Sniffen et al., 1992). In this model, feed CP is divided into five fractions (A, $\mathrm{B}_{1}, \mathrm{~B}_{2}$, $\mathrm{B}_{3}$, and $\mathrm{C}$ ) with different rates of ruminal degradation (NRC, 2001). Fraction A represents NPN, and fraction $\mathrm{C}$ is the protein combined with acid detergent fiber (ADF) and is assumed to be rumen undegradable (NRC, 2001). The three parts of fraction B are thought to be potentially degradable. Fraction $\mathrm{B}_{1}$ protein can be soluble in a borate-phosphate buffer and precipitated with trichloroacetic acetic (TCA) (NRC, 2001). The difference between proteins associated with neutral detergent fiber (NDF) and ADF belong to $\mathrm{B}_{3}$ protein (NRC, 2001). Fraction $\mathrm{B}_{2}$ accounts the remainder of $\mathrm{CP}$ (NRC, 2001). The proportions of CP fractions in feedstuffs should be evaluated when considering AA availability for health and production.

Besides the varied percentages of fractions, the $\mathrm{CP}$ content in feedstuffs can vary considerably. For instance, the content of CP for blood and feather meal exceed $90 \%$ of DM (NRC, 2001). A high amount of protein in feather meal is within fraction $\mathrm{C}$ because the protein 
is extensively cross-linked with disulfide bonds whereas a majority of the protein in fish meal (40\% CP) exists as fraction B (NRC, 2001). The quality of RUP in animal proteins like blood or fish meal can complement the requirements of the dairy cow. Animal meat meal contains around $55 \% \mathrm{CP}$ (NRC, 2001), and has a great portion of the protein belonging to fraction $\mathrm{C}$ (NRC, 2001). Corn gluten meal, soybean meal, and cottonseed are also beneficial protein sources and contain around 65, 50 and 23\% CP, respectively (NRC, 2001). Brewers grain, distillers grain, corn gluten meal or heat-treated soybeans have high amounts of RUP like animal derived proteins. Corn silage $(10 \% \mathrm{CP})$, grasses $(10 \% \mathrm{CP})$ and legume $(20 \% \mathrm{CP})$ forages contain the highest and most variable concentrations of NPN among other protein feedstuffs. Previous work by Fairbairn et al. (1988) and Van Soest (1994) showed that wilted or fermented hay and silage have higher amounts of NPN than fresh feed due to proteolysis (active proteases and peptidases).

\section{Protein digestion}

Once RDP passes to the rumen, ruminal microbial digestion increases the availability of peptides, AA, and ammonia for their own growth. Bacteria are the most abundant microorganisms in the rumen $\left(10^{10-11} / \mathrm{ml}\right)$ and more than $40 \%$ of isolated species are capable of producing proteases (Wallace, 1996). Most bacterial proteases are synthesized on the surface of cells (Kopecny and Wallace, 1982) and approximately $10 \%$ of the total proteolytic activity occurs without attaching bacteria (Broderick, 1998). The proteolytic activity of bacteria enables them to uptake, break down, and utilize protein. Protozoa are the less numerous class of ruminal microorganisms $\left(10^{5-6} / \mathrm{ml}\right)$ but contribute a considerable portion $(50 \%)$ of the total microbial biomass due to their large size (Jouany and Ushida, 1999). Protozoa are capable of metabolizing RDP and microbial protein, and assimilating their own proteins (Coleman, 1980). The third 
microorganism group is fungi $\left(10^{3-4} / \mathrm{ml}\right)$ and their contribution to the ruminal degradation of protein is not completely understood (NRC, 2001). Certainly, different feed components can alter the amounts and composition of bacteria, protozoa, and fungi, and further impact the production of microbial protein from RDP.

The proteases produced by bacteria have moderate proteolytic activity, compared to the gastric and pancreatic secretions in dairy cows. This moderate proteolytic activity and long retention time in the rumen contribute to digestion of RDP into peptides and AA. Dietary peptides and free AA can be utilized by bacteria directly. Peptides and AA digested or ingested are incorporated into protein or deaminated to produce volatile fatty acids (VFA), carbon dioxide $\left(\mathrm{CO}_{2}\right)$, or ammonia in bacteria (Wallace, 1996; Rodriguez et al., 2007). Additionally, bacteria converts NPN to ammonia directly. Ammonia can then be used by microbes that digest structural carbohydrates to produce protein (Russell et al., 1992). The extensive protein degradation and insufficient energy can facilitate the production of ammonia. Excess ammonia is absorbed through the lining of the tract and then transformed into urea in the liver via the urea cycle. The formed urea may be recycled to the rumen via saliva or excreted in the urine.

Protozoa are an important contributor to microbial protein since they utilize AA from RDP as well as from bacteria (Firkins et al., 2007). The protein turnover increases as the bacteria are ingested by protozoa so that the efficiency of nitrogen utilization reduces (Ushida et al., 1991). However, Newbold et al. (2005) recently found evidence demonstrating that protozoa can potentially incorporate ammonia directly for the synthesis of microbial protein. Additional research should be performed to evaluate the roles of protozoa on the formation of microbial protein. 
Overall, the process of microbial protein synthesis in the rumen is complicated because of many factors including the source of proteins and carbohydrates, levels of voluntary intake, feeding frequency, and the forage to concentrate ratio (Fébel and Fekete, 1996). It has been demonstrated that soluble sugars (sucrose, lactose and fructose) increase microbial protein synthesis more than starch feeding from cereal grains (Chamberlain et al., 1993). Conversely, a low rate of microbial protein synthesis can happen when cows are fed excessive cellulose as an energy source (Hespell, 1988). This result contributes to the slow degradation of cellulose. In addition to these carbohydrates and $\mathrm{N}$ sources, other substrates are required to gain optimal microbial growth such as fat and true protein (Block, 2006).

Upon removal from the rumen, microbial protein and RUP enter the reticulum and omasum with little modification. Protein reaching the abomasum is digested in response to strong acids and digestive enzymes including pepsinogen and lysozyme. Abomasal acids activate pepsinogen into pepsin, which initiates the digestion of proteins. Trypsin and chymotrypsin, proenzymes from the pancreas, enter the lumen of the small intestine and further break down proteins. Collectively, microbial protein or RUP is digested into peptides and AA before they are absorbed by the small intestine.

\section{Metabolic utilization of circulating amino acids}

The true protein digested postruminally and absorbed as AA by the intestines is defined as metabolizable protein (MP). The MP requirements of a dairy cow are largely based on the milk and milk components productions, BW, stage of growth, and pregnancy or lactation. Equations for calculating MP are available in different stages and give the guidance to formulate 
diets (NRC, 2001). Dairy cows utilize individual AA of MP to produce enzymes and hormones, synthesize milk protein, replace muscle tissue, and support fetal growth.

The majority of AA reaching the liver are derived from the dietary AA and arterial delivery (Apelo et al., 2014). The deamination of AA provides carbon skeletons to form nonessential AA (NEAA) or they are directed toward the Krebs cycle either for gluconeogenesis or for lipogenesis in liver (Bequette, and Nelson, 2006). The excess nitrogen is ultimately transaminated to form alanine (Ala), aspartic acid (Asp), glutamine (Gln) or glutamate (Glu) for entry into the ornithine cycle to produce urea (Bequette, and Nelson, 2006). Circulating AA coming from the liver can be transported to the peripheral tissues (e.g. muscle) and mammary gland for further utilization.

\section{Dairy cow biology}

\section{Mammary gland biology and milk synthesis}

The mammary gland system in a dairy cow includes four systems: a supportive system composed of lateral and median suspensory ligament, a secretory system composed of alveoli, a duct system for storage and conveyance of milk, and blood, lymph and nerve systems that transport substrates (e.g. AA, glucose, and fatty acids (FA)) and endocrine signals to the mammary gland (Ferreira et al., 2013). The epithelial cells in alveoli are the basic functional units that are responsible for milk synthesis. Overall, the main function of the mammary gland is to assemble substrates from blood into protein, lactose, and triacylglycerol (TAG) in milk. The

process for mammary gland development starts at embryonic development, completes at puberty, obtains maximum function through pregnancies and lactations, and involutes when milk production ceases. Each step involves differentiation, proliferation and apoptosis of cells and is 
under the regulation of hormonal, metabolic and genetic expression (Ferreira et al., 2013). For each lactation cycle, the amount of secretory tissue in mammary gland increases during the close-up period and decreases during late lactation. The endocrine system plays an important role in this dynamic change of mammary gland function. Prolactin, growth hormone, and progesterone signal the cell differentiation in the mammary gland (Neville et al., 2002; Akers, 2006;). Furthermore, estrogen initiates mammary gland involution (Athie et al., 1996). During lactation, prolactin and glucocorticoids stimulate epithelial cells to maintain milk production (Akers, 2006; Feng et al., 1995).

True protein, fat, and lactose are three main components in milk. It is well known that the efficiency of converting dietary nitrogen into milk is about 25 to $30 \%$ (Bequette et al., 1998). As for milk protein, the major proteins that represent approximately $92 \%$ of bovine milk proteins including caseins ( $\alpha-\mathrm{CN}, \beta-\mathrm{CN}, \mathrm{k}-\mathrm{CN}$, and $\gamma-\mathrm{CN}$ ) and whey proteins ( $\beta-\mathrm{LG}$ and $\alpha-\mathrm{LA})$. The remainder includes albumin and immunoglobulin. During lactation, peptides and AA in blood are extracted by the mammary gland and total AA utilized in the mammary gland can be monitored by an arteriovenous kinetic technique (Bequette et al., 1996). The requirement of the mammary gland for essential AA (EAA) such as branched-chain AA (BCAA) (isoleucine (Ile), leucine (Leu) and valine (Val)), lysine (Lys) and threonine (Thr) appear to be higher since their extraction generally exceeds output of milk protein (Bequette et al., 1998). The uptake of methionine (Met), histidine (His), phenylalanine (Phe), and tryptophan (Trp) is considerably less than the amounts that are incorporated into milk protein (Bequette et al., 1998). For NEAA, the net uptake is less than that required for the synthesis of milk protein (Manjarin, 2014). The mammary gland would also catabolize some EAA to produce deficient NEAA to assemble milk protein. For instance, Met provides sulfur groups for cysteine (Cys) synthesis in addition to the 
incorporation into protein. Branched-chain AA provide carbon skeletons for NEAA synthesis after they are catabolized by the mammary gland (Lei et al., 2012). The AA left could be involved into the synthesis of milk fat. According to Young et al. (1994), BCAA including Ile Leu, and Val and are catabolized by mammary gland along pathways found in other tissues to produce organic acids and $\mathrm{CO}_{2}$. Lastly, beside the part incorporated in milk protein, Lys may be oxidized to provide ketogenic intermediates (Bequette et al., 1998).

Milk fat (95\% TAG) is the most variable component in milk and is usually around $4 \%$ in dairy cows. Over 400 species of molecular FAs are composed of TAG in milk (Jensen, 2002). The FA utilized for fat synthesis in milk come from either de novo synthesis (short or mediumchain FA) in epithelial cells of mammary gland or uptake from circulation (long-chain FA) (Neville and Picciano, 1997). The former source contributes 50\% of milk fat (Bauman and Davis, 1974) and mainly utilize acetate from the fermentation of carbohydrates in the rumen. The FA in blood come from circulating lipoproteins such as very low-density lipoprotein (VLDL), lowdensity lipoprotein (LDL) and chylomicrons (CM), and non-esterified FA (NEFA) from mobilization of adipose tissue (Bauman and Davis, 1974).

Milk lactose is the main osmotic regulator for the uptake of water in milk and percentage of milk lactose in dairy cows is consistently $5 \%$. Lactose is a disaccharide sugar that consists of galactose and glucose. In the Golgi lumen of mammary gland cells, a lactose synthase, galactosyl transferase catalyzes the condensation of UDP-galactose and D-glucose to form lactose (Mellenberger et al., 1973).

\section{Negative energy balance in peripartal dairy cows}

The transition period for dairy cows is characterized as three weeks before to three weeks after calving (Drackley, 1999). During the transition period, the requirements for nutrients 
increase due to fetal growth, development of the mammary glands, and initiation of milk production. Additionally, an increase in dry matter intake (DMI) lags far behind nutrient requirements because the fetus occupies abdominal space and physiological factors such as hormones (e.g. estrogen) inhibit DMI (Grummer et al., 1990). Hence, dramatic metabolic adaptations develop as peripartal dairy cows transition from gestation to lactation. As a result, the early lactation dairy cow will enter a state of negative energy, protein and mineral balance. According to Grummer (1995), negative energy balance (NEB) develops prepartum but is greatest the first week postpartum. To meet the requirements of energy, cows mobilize adipose tissue TAG into NEFA and glycerol. This process is promoted in part by increased insulin resistance in adipose tissue coupled with decreased insulin secretion from the pancreas (Bell, 1995).

In turn, circulating NEFA can be incorporated into milk fat or utilized by peripheral tissues for energy. Additionally, plasma NEFA are extracted by the liver where they are partially oxidized to acetyl-coenzyme A (CoA), which supports adenosine ATP synthesis (Donkin, 2012). Increased acetyl-CoA from NEFA oxidation can also support ketogenesis in the peripartial dairy cow which increases the availability of acetone, acetoacetate and $\beta$-hydroxybutyrate (BHBA). In addition to oxidation, NEFA can also be reesterified to TAG, which are incorporated with apoproteins (Apo) and cholesterol, and released into blood as VLDL (Grummer, 1993).

For TAG that can't be released into blood as VLDL, hepatic lipid deposition ensues (Grummer, 1993). Compared with monogastric animals, the capacity to form VLDL in ruminants is limited (Pullen et al., 1990). In peripartal dairy cows, suppressed VLDL secretion from liver can result in the development of fatty liver disease. Fatty liver disease is defined as the percentage of TAG that can cause detrimental effects to the health, well-being, productivity, or 
reproductive success of a dairy cow (Bobe et al., 2004). Based on the percentage of TAG, fatty liver has been divided into three categories: clinical fatty liver (10\% TAG), moderate fatty liver (5 and 10\% TAG), and mild fatty liver (1 and 5\% TAG). The development of fatty liver impairs the normal function, and decreases the capacity for ureagenesis and gluconeogenesis (Strang et al., 1998).

\section{Peripartal diseases}

Peripartal diseases that may develop in dairy cows during the transition period are divided into disproportional energy metabolism diseases (fatty liver, ketosis, subacute, acute ruminal acidosis), disturbed mineral utilization diseases (milk fever, sub-clinical hypocalcaemia), and, perturbed immune function (retained placenta, metritis and mastitis) (Esposito et al., 2014).

Ketosis is characterized by abnormally elevated ketone bodies in the blood and tissues including acetoacetate, acetone, and BHBA. Ketosis is classified into clinical (over 1400 $\mu \mathrm{mol} / \mathrm{L}$ ) or subclinical (over $1200 \mu \mathrm{mol} / \mathrm{L}$ ) based on the concentrations of ketones in the body (Jorritsma et al., 1998). For dairy cows with clinical ketosis, excess loss of BW, reduced appetite, reduced activity and milk yield, and hard feces are common symptoms. Over $50 \%$ of dairy cows are thought to experience a temporary period of subclinical ketosis within one month after calving (Esposito et al., 2014), typically occuring 21-28 days postpartum following the development of fatty liver disease (Ringseis et al., 2015). Decreased DMI due to ketosis reduces rumen fill and increases the incidence of displaced abomasum (Van Winden et al., 2003) since increased gas exists in the abomasum. Nearly $50 \%$ of diagnosed left displaced abomasum cases are coupled with NEB (Heuer, 2000). 
During the transition period, periparturient immunosuppression can develop (Kehrli et al., 2006). Previous research has shown that ketones have a detrimental effect on the activity of leucocytes and probably contributes to impaired immune function. In addition, progesterone plays a role in suppressing immune responses (Padua et al., 2005) as well as the differentiation of regulatory immune cells (Esposito et al., 2014). Overall, a large number of components related to the host defense system are altered during the transition period, including neutrophil function, lymphocyte and antibody responsiveness, and cytokine production (Goff, 2006; Kehrli et al., 2006). Immune suppression is consider as the main influencing factor of infection, primarily mastitis and metritis during the transition period (Kimura et al., 2002).

Under the high peripartal demand of calcium, cows mobilize calcium in muscle tissues to compensate for the requirement of fetal growth and milk production. As time progresses, the cow fails to maintain normal blood calcium concentration, which is called milk fever. The incidence

of clinical milk fever in the U.S. is approximately 5\% (McLaren et al., 2006), whereas about 50\% of peripartal cows experience subclinical hypocalcaemia (Reinhardt et al., 2011).

The metabolic challenges during the transition period cause reduced fertility and milk production which negatively impact dairy producer profitability (Wensing et al., 1997). One study by Duffield et al. (2009) showed that NEB results in substantial loss in milk yield during the early lactation period. Furthermore, the interval between calving and first service, from calving to conception was longer in cows with metabolic diseases (Raboisson et al., 2014).

\section{Lipoprotein metabolism}

The occurrence of fatty liver disease in periparturient dairy cows develops in response to the reduced capacity to export VLDL. The structure, synthesis and secretion process of VLDL in 
ruminants are thought to be similar across mammalian species (Bauchart, 1993). Lipoprotein, VLDL, is composed of TAG, phospholipids, cholesterol, cholesterol esters and several Apo (B100, C-I, C-II, C-III, E-2, E-3, and E-4). The FAs used to synthesize these complex lipids come from four main sources: de novo lipogenesis, cytoplasmic TAG stores, lipoproteins absorbed by the liver, and NEFA in the blood (Lewis, 1997). Exogenous TAG can't be incorporated into VLDL directly; therefore, they undergo lipolysis and then are re-esterified into newly-formed TAG (Julius, 2003). The assembly of hepatic VLDL starts in the smooth endoplasmic reticulum, where TAG, phospholipids, cholesterol and cholesterol esters are synthesized (Vance, 1990). Under the assistance of microsomal triglyceride transfer protein (MTTP), all of the lipid components are packaged with Apo B-100, a protein synthesized on ribosomes bound to the rough endoplasmic reticulum (White et al., 1998). The newly formed VLDL carried by transport vesicles moves from endoplasmic reticulum to Golgi, where modification of the oligosaccharide components of the Apos and some exchange of phospholipids occur (Vance et al., 1990). After a series of modifications, secretory vesicles with mature VLDL move to the cell surface and release the VLDL into circulation via exocytosis (Vance et al., 1990).

In dairy cows, the limited VLDL might be caused by inadequate phospholipid supply. There are two possible reasons: low concentrations of choline and phospholipids in plants, and their extensive ruminal degradation (Sharma and Erdman, 1989). With insufficient lipid component supply, MTTP can not translocate Apo B-100 into the lumen of endoplasmic reticulum so that this protein is degraded in cells (White et al., 1998). Hence, dairy cows will not form and secret enough VLDL to blood and in turn fat accumulates in liver. 


\section{Micronutrient supplementation in dairy cows}

To improve the synthesis of VLDL and milk production performance, supplementation of Met, choline, and betaine with rumen-protection (RP) has been applied widely in research and industry. The metabolic pathways for these three micronutrients are closely interrelated. Choline is associated with the production of phosphatidylcholine (PC) of VLDL. Hepatic PC can also be synthesized through tri-methylation of phosphatidylethanolamine (PE). Methionine is the source of methyl donor S-adenosylmethionine that provides methyl groups for the synthesis of PC from PE. Additionally, choline can be oxidized into betaine, which is able to provide a methyl group, for the formation of Met from homcysteine. Furthermore, Met can be used to synthesize Apos directly. Overall, the addition of Met, choline, and betaine could possibly promote the synthesis and secretion of VLDL and reduce the severity of fatty liver, and improve milk production.

\section{Choline supplementation}

Choline is a tri-methyl ethanolamine and essential nutrient in ruminants. Feedstuffs including barley, cottonseed meal, fish meal, soybean meal, choline stearate, and choline chloride are sources of choline; however, choline undergoes high (80-98\%) degradation in the rumen (Sharma and Erdman, 1989). Dietary choline is converted to tri-methylamine and then methane in the rumen. Choline that escapes ruminal degradation is insufficient to meet requirement of dairy cows. Hence, RP-choline is required to increase its supply and availability in the small intestine. In most previous studies, the common amount of choline supplemented was $15 \mathrm{~g} / \mathrm{d}$, and at most $50 \mathrm{~g} / \mathrm{d}$. Supplementation with RP-choline decreased circulating NEFA and liver TAG accumulation in far-off dry cows with fatty liver caused by feed restriction (Cooke et al., 2007). Elevated milk yield, fat-corrected milk (FCM), and fat and protein yield 
were found in periparturient dairy cows with choline supplementation $(25 \mathrm{~g} / \mathrm{d}$ prepartum; $50 \mathrm{~g} / \mathrm{d}$ postpartum) (Elek et al., 2008). One study by Zom et al. (2011) observed increased DMI and decreased hepatic TAG but no modifications on milk yield, milk fat and protein yield in periparturient dairy cows after the addition of RP-choline (14.4 g/d). Feeding $15 \mathrm{~g} / \mathrm{d}$ RP-choline reduced the incidence of clinical ketosis, mastitis and morbidity in early lactation cow (Lima et al., 2012).

\section{Betaine supplementation}

Betaine ( $N, N, N$-trimethylglycine), a small zwitterionic compound that is primarily found in shellfish, wheat, beetroot, and silverbeet (De Zwart et al., 2003). Betaine research is limited in dairy cows. In early lactation period, no effects of RP-betaine has been found to improve production performance and health condition (Davidson et al., 2008). During mid-lactation period, supplementation of anhydrous betaine could lower the concentrations of NEFA and BHBA (Wang et al., 2010). In addition, a linear increase in milk yield and FCM, and a quadratic increase in milk fat percentage were observed as increased anhydrous betaine supplementation (50, 100, and $150 \mathrm{~g} / \mathrm{d}$ ) during mid-lactation period (Wang et al., 2010). By Peterson et al. (2012), increased milk yield but decreased milk percentage were found when supplementing betaine $(100 \mathrm{~g} / \mathrm{d})$ without RP.

\section{Methionine and lysine supplementation}

The multiple components pricing system has been used since 2000 and this system has fundamentally altered milk pricing system from a previous one based on milk volume adjusted for milk fat content to one determined primarily on the amounts of milk components including 
fat, protein, lactose, and minerals produced (Vyas et al., 2009). Dairy producers have a greater interest in utilizing means to improve milk protein yield due to the increased value of milk. As we mentioned before, the AA profile of microbial protein is comparable to milk protein but the RUP AA profile is always imbalanced. To improve the utilization of AA in RUP and increase milk protein production, specific AA deficient in RUP must be added with RP to balance the AA profile. In corn silage and alfalfa haylage-based U.S. commercial diets, Met and Lys are the first two limiting AA for milk protein synthesis (NRC, 2001). The addition of these AA has the potential to decline urea production and reduces environmental pollution.

The protection of Met and Lys with saturated fats (particularly C16:0 and C18:0) can decrease the degradation of AA in the rumen (Sacadura et al., 2008). By analyzing 54 comparisons between control and RP-Met and Lys supplementation diets, Robinson (2010) suggested that supplementation of these two AA together increases milk protein percentage, milk yield, milk energy output, the milk/DM ratio as well as the efficiency of utilization of dietary nitrogen for milk protein. Research that has evaluated only Met supplementation has observed increased milk energy output, milk fat and protein percentage and improved efficiency to convert dietary nitrogen into milk protein (Robinson, 2010). Furthermore, studies evaluating only Lys supplementation have observed decreased DMI compared to control diets (Robinson et al., 2010).

Studies have evaluated the co-supplementation of Met and Lys, results are inconsistent because of variable doses of supplementation, basal diets and stages of lactation (Armentano et al., 1997; Donkin et al., 1989; Socha et al., 2008). However, increased milk protein percentage after combined supplementation of Met and Lys is frequently observed. Socha et al. (2008) observed a linear increase in milk protein percentage but linear decrease in milk fat yield, FCM, and energy-corrected milk (ECM) with supplementation of Lys (8 g/d) and Met $(0,5,10,15,20$ 
$\mathrm{g} / \mathrm{d})$. The supplementation of Met $(15 \mathrm{~g} / \mathrm{d})$ and Lys $(40 \mathrm{~g} / \mathrm{d})$ increased the percentage and yield of milk protein and increased milk urea nitrogen (MUN) (Donkin et al., 1989). In one early lactation study, Armentano et al. (1997) detected that the supplementation of Lys (14.7 g/d) and Met $(5.25,10.5,11.5 \mathrm{~g} / \mathrm{d})$ increased milk protein percentage, and milk protein yield linearly. Studies evaluating micronutrient supplementation including Met, choline and betaine are needed to help dairy producers identify feeding management strategies to improve their profit margins. 


\section{Literature Cited}

Abdo, K. M., K. W. King, and R. W. Engel. 1964. Protein quality of rumen microorganisms. J. Anim. Sci. 23:734-736.

Akers, R. M. 2006. Major advances associated with hormone and growth factor regulation of mammary growth and lactation in dairy cows. J. Dairy Sci. 89:1222-1234.

Apelo, S. A., J. R. Knapp, and M. D. Hanigan. 2014. Invited review: Current representation and future trends of predicting amino acid utilization in the lactating dairy cow. J. Dairy Sci. 97:4000-4017.

Armentano, L. E., S. J. Bertics, and G. A. Ducharme. 1997. Response of lactating cows to methionine or methionine plus lysine added to high protein diets based on alfalfa and heated soybeans. J. Dairy Sci. 80:1194-1199.

Athie, F., K. C. Bachman, H. H. Head, M. J. Hayen, and C. J. Wilcox. 1996. Estrogen administered at final milk removal accelerates involution of bovine mammary gland. $\mathrm{J}$. Dairy Sci. 79:220-226.

Bauchart, D. 1993. Lipid absorption and transport in ruminants. J. Dairy Sci. 76:3864-3881.

Bauman, D. E. and C. L. Davis. 1974. Biosynthesis of milk fat. In: Larson B. L., Smith V. R., editors. 1974. VR Smith Lactation: A Comprehensive Treatise. New York: Academic. $2: 31-75$.

Bell, A. W. 1995. Regulation of organic nutrient metabolism during transition from late pregnancy to early lactation J. Anim. Sci. 76:2804-2819.

Bequette, B. J., F. R. C. Backwell, and L. A. Crompton. 1998. Current concepts of amino acid and protein metabolism in the mammary gland of the lactating ruminant. J. Dairy Sci. 81:2540-2559.

Bequette, B. J., J. A. Metcalf, D. Wray-Cahen, F. R. Colette Backwell, J. D. Sutton, M. A. Lomax, J. C. Macrae, and G. E. Lobley. 1996. Leucine and protein metabolism in the lactating dairy cow mammary gland: responses to supplemental dietary crude protein intake. J. Dairy Res. 63:209-222.

Bequette, B. J. and K. Nelson. 2006. The roles of amino acids in milk yield and components. In: Florida ruminant Nutrition Symposium; February; Florida. 1(2).

Block, E. 2006. Rumen microbial protein production: Are we missing an opportunity to improve dietary and economic efficiencies in protein nutrition of the high producing dairy cow? In: High Plains Dairy Conference; February; Albuquerque, New Mexico. 33-44. 
Broderick, G. A. 1998. Can cell-free enzymes replace rumen micro-organisms to model energy and protein supply? In: Deaville E. R., Owen E., Adegosan A.T., Rymer C., Huntington J. A., Lawrence T. L. J., editors. 1998. Vitro techniques for measuring nutrient supply to ruminants. Edinburgh (UK): Occasional Publication. 22:99-114.

Bobe, G., J. W. Young, and D. C. Beitz. 2004. Invited review: pathology, etiology, prevention, and treatment of fatty liver in dairy cows. J. Dairy Sci. 87:3105-3124.

Chamberlain, D, G., S, Robertson, and J. J. Choung. 1993. Sugars versus starch as supplements to grass silage: effects on ruminal fermentation and the supply of microbial protein to the small intestine, estimated from the urinary excretion of purine derivatives, in sheep. J. Sci. Food N. Agric. 63:189-194.

Clark, J. H., T. H. Klusmeyer, and M. R. Cameron. 1992. Microbial protein synthesis and flows of nitrogen fractions to the duodenum of dairy cows. J. Dairy Sci. 75:2304-2323.

Coleman, G. S. 1980. Rumen ciliate protozoa. Adv. Parasitol. 18:121-173.

Cooke, R. F., N. Silva Del Rio, D. Z. Caraviello, S. J. Bertics, M. H. Ramos, and R. R. Grummer. 2007. Supplemental choline for prevention and alleviation of fatty liver in dairy cattle. J. Dairy Sci. 90:2413-2418.

Davidson, S., B. A. Hopkins, J. Odle, C. Brownie, V. Fellner, and L. W. Whitlow. 2008. Supplementing limited methionine diets with rumen-protected methionine, betaine, and choline in early lactation Holstein cows. J. Dairy Sci. 91:1552-1559.

De Zwart, F. J., S. Slow, R. J. Payne, M. Lever, P. M. George, J. A. Gerrard, and S. T. Chambers. 2003. Glycine betaine and glycine betaine analogues in common foods. Food Chem. 83:197-204.

Donkin, S. S. The role of liver metabolism during transition on postpartum health and performance. 2012. Florida Ruminant Nutrition Symposium Proceedings; 2012; Florida. 97-106.

Donkin, S. S., G. A. Varga, T. F. Sweeney, and L. D. Muller. 1989. Rumen-protected methionine and lysine: effects on animal performance, milk protein yield, and physiological measures. J. Dairy Sci. 72:1484-1491.

Drackley, J. K. 1999. Biology of dairy cows during the transition period: The final frontier? J. Dairy Sci. 82:2259-2273.

Duffield, T. F., K. D. Lissemore, B. W. McBride, and K. E. Leslie. 2009. Impact of hyperketonemia in early lactation dairy cows on health and production. J. Dairy Sci. 92:571-580. 
Elek, P., J. R. Newbold, T. Gaal, L. Wagner, and F. Husveth. 2008. Effects of rumen-protected choline supplementation on milk production and choline supply of periparturient dairy cows. Anim. 2:1595-1601.

Erasmus, L. J., P. M. Botha, C. W. Cruywagen, and H. H. Meissner. 1994. Amino acid profile and intestinal digestibility in dairy cows of rumen-undegradable protein from various feedstuffs. J. Dairy Sci. 77:541-551.

Esposito, G., P. C. Irons, E. C. Webb, and A. Chapwanya. 2014. Interactions between negative energy balance, metabolic diseases, uterine health and immune response in transition dairy cows. Anim. Reprod. Sci. 144:60-71.

Fairbairn, R. L., I. Alli, and L. E. Phillip. 1992. Proteolysis and amino acid degradation during ensilage of untreated or formic acid-treated lucerne and maize. Grass N. Forage Sci. 47:382-390.

Fébel, H. and S. Fekete. 1995. Factors influencing microbial growth and the efficiency of microbial protein synthesis: a review. Acta Vet. Hungarica. 44:39-56.

Feng, Z., A. Marti, B. Jehn, H. J. Altermatt, G. Chicaiza, and R. Jaggi. 1995. Glucocorticoid and progesterone inhibit involution and programmed cell death in the mouse mammary gland. J. Cell Biol. 131:1095-1103.

Ferreira, A. M., S. L. Bislev, E. Bendixen, and A. M. Almeida. 2013. The mammary gland in domestic ruminants: a systems biology perspective. J. Proteome. 94:110-123.

Firkins, J. L., Z. Yu, and M. Morrison. 2007. Ruminal nitrogen metabolism: perspectives for integration of microbiology and nutrition for dairy 1, 2. J. Dairy Sci. 90:E1-E16.

Goff, J. P. 2006. Major advances in our understanding of nutritional influences on bovine health. J. Dairy Sci. 89:1292-1301.

Grummer, R. R. 1993. Etiology of lipid-related metabolic disorders in periparturient dairy cows. J. Dairy Sci. 76:3882-3896.

Grummer, R. R. 1995. Impact of changes in organic nutrient metabolism on feeding the transition dairy cow. J. Anim. Sci. 73:2820-2833.

Grummer, R. R., S. J. Bertics, D. W. Lacount, J. A. Snow, M. R. Dentine, and R. H. Stauffacher. 1990. Estrogen induction of fatty liver in dairy cattle. J. Dairy Sci. 73:1537-1543.

Hespell, R. B. 1988. Microbial digestion of hemicelluloses in the rumen. Mol. Microbiol. 5:362365.

Heuer, C. 2000. Negative energy balance in dairy cows: prediction, consequences, prevention. Utrecht Univ. 
Jensen, R. G. 2002. The composition of bovine milk lipids: January 1995 to December 2000. J. Dairy Sci. 85:295-350.

Jorritsma, R., S. J. C. Baldee, Y. H. Schukken, Th Wensing, and G. H. Wentink. 1998. Evaluation of a milk test for detection of subclinical ketosis. Vet. Q. 20:108-110.

Jouany, J. P. and K. Ushida. 1999. The role of protozoa in feed digestion-Review. AsianAustralas. J. Anim. Sci. 12:113-128.

Julius, U. 2003. Influence of plasma free fatty acids on lipoprotein synthesis and diabetic dyslipidemia. Exp. N. Clin. Endocrinol. N. Diabetes. 111:246-250.

Kehrli, M. E., J. D. Neill, C. Burvenich, J. P. Goff, J. D. Lippolis, T. A. Reinhardt, and B. J. Nonnecke. 2006. Energy and protein effects on the immune system. In: Sejrsen K., Hvelplund T., Nielsen M. O., editors. Ruminant physiology. Digestion, metabolism and impact of nutrition on gene expression, immunology and stress. Netherlands: Wageningen Academic Publishers. 455-471.

Kimura, K, J. P. Goff, M. E. Kehrli, J. A. Harp, and B. J. Nonnecke. 2002. Effects of mastectomy on composition of peripheral blood mononuclear cell populations in periparturient dairy cows. J. Dairy Sci. 85:1437-1444.

Kopecny, J. and R. J. Wallace. 1982. Cellular location and some properties of proteolytic enzymes of rumen bacteria. Appl. N. Environ. Microbiol. 43:1026-1033.

Lei, J., D. Y. Feng, Y. L. Zhang, F. Q. Zhao, Z. L. Wu, A. S. Gabriel, Y. Fujishima, H. Uneyama, and G. Wu. 2012. Nutritional and regulatory role of branched-chain amino acids in lactation. Front Biosci. 17:725-2.

Lewis, G. F. 1997. Fatty acid regulation of very low density lipoprotein production. Curr. Opin. Lipidol. 8:146-153.

Lima, F. S., M. F. Sa Filho, L. F. Greco, and J. E. P. Santos. 2012. Effects of feeding rumenprotected choline on incidence of diseases and reproduction of dairy cows. Vet. J. 193:140-145.

Manjarin, R., B. J. Bequette, G.Y. Wu, and N. L. Trottier. 2014. Linking our understanding of mammary gland metabolism to amino acid nutrition. Amino Acids. 46:2447-2462.

McLaren, C. J., K. D. Lissemore, T. F. Duffield, K. E. Leslie, D. F. Kelton, and B. Grexton. 2006. The relationship between herd level disease incidence and a return over feed index in Ontario dairy herds. Can. Vet. J. 47:767. 
Mellenberger, R. W., D. E. Bauman, and D. R. Nelson. 1973. Metabolic adaptions during lactogenesis: Fatty acid and lactose synthesis in cow mammary tissue. Biochem. J. 136:741-748.

Neville, M. C., M. F. Picciano. 1997. Regulation of milk lipid secretion and composition. Annu. Rev. Nutr. 17:159-84.

Neville, M. C., T. B. McFadden, and I. Forsyth. 2002. Hormonal regulation of mammary differentiation and milk secretion. J. Mammary Gland Bio. N. Neoplas. 7:49-66.

Newbold, C. J., N. R. McEwan, R. E. Calza, E. N. Chareyron, S. M. Duval, S. C. P. Eschenlauer, F. M. McIntosh, N. Nelson, A. J. Travis, and R. J. Wallace. 2005. An NAD+-dependent glutamate dehydrogenase cloned from the ruminal ciliate protozoan, Entodinium caudatum. FEMS Microbiol. Lett. 247:113-121.

NRC. 2001. Nutrient Requirements of Dairy Cattle. 7th rev. ed. Natl. Acad. Sci., Washington, DC.

Padua, M. B., Ş. Tekin, T. E. Spencer, and P. J. Hansen. Actions of progesterone on uterine immunosuppression and endometrial gland development in the uterine gland knockout (UGKO) ewe. Mol. Repro. N. Dev.71, no. 3 (2005): 347-357.

Peterson, S. E., P. Rezamand, J. E. Williams, W. Price, M. Chahine, and M. A. McGuire. 2012. Effects of dietary betaine on milk yield and milk composition of mid-lactation Holstein dairy cows. J. Dairy Sci. 95:6557-6562.

Pullen, D. L., J. S. Liesman, and R. S. Emery. 1990. A species comparison of liver slice synthesis and secretion of triacylglycerol from nonesterified fatty acids in media. J. Anim. Sci. 68:1395-1399.

Raboisson, D., M. Mounie, and E. Maigne. 2014. Diseases, reproductive performance, and changes in milk production associated with subclinical ketosis in dairy cows: a metaanalysis and review. J. Dairy Sci. 97:7547-7563.

Reinhardt, T. A., J. D. Lippolis, B. J. McCluskey, J. P. Goff, and R. L. Horst. 2011. Prevalence of subclinical hypocalcemia in dairy herds. Vet. J. 188:122-124.

Ringseis, R., D. K. Gessner, and K. Eder. 2015. Molecular insights into the mechanisms of liverassociated diseases in early-lactating dairy cows: hypothetical role of endoplasmic reticulum stress. J. Anim. Physiol. N. Anim. Nutr. 99:626-645.

Robinson, P. H. 2010. Impacts of manipulating ration metabolizable lysine and methionine levels on the performance of lactating dairy cows: A systematic review of the literature. Livest. Sci. 127:115-126. 
Rodríguez, R., A. Sosa, and Y. Rodríguez. 2007. Microbial protein synthesis in rumen and its importance to ruminants. Cuban J. Agric. Sci. 41:287-294.

Russell, J. B., J. D. O'connor, D. G. Fox, P. J. Van Soest, and C. J. Sniffen. 1992. A net carbohydrate and protein system for evaluating cattle diets: I. Ruminal fermentation. J. Anim. Sci. 70:3551-3561.

Sacadura, F. C., P. H. Robinson, E. Evans, and M. Lordelo. 2008. Effects of a ruminally protected B-vitamin supplement on milk yield and composition of lactating dairy cows. Anim. Feed Sci. N. Tech. 144:111-124.

Sharma, B. K. and R. A. Erdman. 1989. In Vitro Degradation of Choline from Selected Foodstuffs and Choline Supplements 1, 2. J. Dairy Sci. 72:2772-2776.

Sniffen, C. J., J. D. O'connor, P. J. Van Soest, D. G. Fox, and J. B. Russell. 1992. A net carbohydrate and protein system for evaluating cattle diets: II. Carbohydrate and protein availability. J. Anim. Sci. 70:3562-3577.

Socha, M. T., C. G. Schwab, D. E. Putnam, N. L. Whitehouse, B. D. Garthwaite, and G. A. Ducharme. 2008. Extent of Methionine Limitation in Peak-, Early-, and Mid-Lactation Dairy Cows 1, 2. J. Dairy Sci. 91:1996-2010.

Strang, B. D., S. J. Bertics, R. R. Grummer, and L. E. Armentano. 1998. Effect of long-chain fatty acids on triglyceride accumulation, gluconeogenesis, and ureagenesis in bovine hepatocytes. J. Dairy Sci. 81:728-739.

Ushida, K., J. Jouany, and D. Demeyer. 1991. Effects of the presence or absence of rumen protozoa on the efficiency of utilisation of concentrate and fibrous feeds. In: Tsuda' T., Sasaki Y., Kawashima R., editors. Physiological Aspects of Digestion and Metabolism in Ruminants', Proc, 7th International Symposium on Ruminant Physiology; 1991; New York. New York: Academic Press. 625-654.

Van Soest, P. J. 1994. Nutritional Ecology of the Ruminant ( $2^{\text {nd }}$ ed.) Cornell University Press, Ithaca, NY

Van Winden, S. C. L., R. Jorritsma, K. E. Müller, and J. P. T. M. Noordhuizen. 2003. Feed intake, milk yield, and metabolic parameters prior to left displaced abomasum in dairy cows. J. Dairy Sci. 86:1465-1471.

Vance, J. E. 1990. Phospholipid synthesis in a membrane fraction associated with mitochondria. J. Biol. Chem. 265:7248-7256.

Vyas, D. and R. A. Erdman. 2009. Meta-analysis of milk protein yield responses to lysine and methionine supplementation. J. Dairy Sci. 92:5011-5018. 
Wallace, R. J. 1996. Ruminal microbial metabolism of peptides and amino acids. J. Nutr. 126:1326S.

Wang, C., Q. Liu, W. Z. Yang, J. Wu, W. W. Zhang, P. Zhang, K. H. Dong, and Y. X. Huang. 2010. Effects of betaine supplementation on rumen fermentation, lactation performance, feed digestibilities and plasma characteristics in dairy cows. J. Agric. Sci. 148:487-495.

Wensing, T., T. Kruip, M. J. H. Geelen, G. H. Wentink, and A. M. Van den Top. 1997. Postpartum fatty liver in high-producing dairy cows in practice and in animal studies. The connection with health, production and reproduction problems. Comp. Haematol. Int. 7:167-171.

White, D. A., A. J. Bennett, M. A. Billett, and A. M. Salter. 1998. The assembly of triacylglycerol-rich lipoproteins: an essential role for the microsomal triacylglycerol transfer protein. Br. J. Nutr. 80:219-229.

Zom, R. L. G., J. Van Baal, R. M. A. Goselink, J. A. Bakker, M. J. De Veth, and A. M. Van Vuuren. 2011. Effect of rumen-protected choline on performance, blood metabolites, and hepatic triacylglycerols of periparturient dairy cattle. J. Dairy Sci. 94:4016-4027. 


\title{
Chapter 3
}

\section{EFFECTS OF RUMEN-PROTECTED METHIONINE, CHOLINE, AND BETAINE ON PERIPARTURIENT DAIRY CATTLE HEALTH AND MILK PRODUCTION PERFORMANCE}

\begin{abstract}
Dairy cows experience fatty liver syndrome due to excess lipid mobilization during the transition from gestation to lactation. The progression of fatty liver disease and other peripartal ailments can compromise milk production and reproductive performance. Methionine (Met), choline, and betaine are involved into the synthesis of very low-density lipoproteins (VLDL) that export triacylglycerol (TAG) from the liver. Therefore, our objective was to investigate the effects of micronutrient co-supplementation on metabolic health and production during the periparturient period. Thirty multiparous Holstein cows independently housed were fed total mixed rations (TMR) with or without micronutrients (22 g/d Met, $10 \mathrm{~g} / \mathrm{d}$ choline chloride, and 3 g/d betaine) from d -28 prepartrum to d 14 postpartrum (Mecovit vs. Control, respectively). All cows received $65 \mathrm{~g} / \mathrm{d}$ of lipid encapsulate composed of $62 \%$ palmitic acid. Milk and blood samples were collected routinely. Liver biopsy samples were collected at d -28, 5, and 14, relative to calving. Milk components, plasma and serum metabolites were measured using midinfrared spectroscopy, colorimetry, immunassay, indirect potentiometry, and gas chromatography tandem mass spectrometry (GC/MS/MS), respectively. Data were analyzed with repeated measures under a mixed model with fixed effects of treatment and time. Times were used as repeated measures. Significant time effects were observed for all milk components, dry matter intake (DMI), body condition score (BCS), body weight (BW), plasma metabolites (nonesterified fatty acids (NEFA), $\beta$-hydroxybutyrate (BHBA), glucose, insulin, TAG, total cholesterol, free cholesterol, and cholesterol esters, VLDL, low-density lipoprotein (LDL)),
\end{abstract}


serum proteins (total protein, albumin, globulin, and hemoglobin), serum Met concentration and percentage of liver lipid. However, milk yield and milk components were not significantly modified by treatment. Micronutrient supplementation had the tendency to increase milk total solids $(\mathrm{TS})$ percentage $(P=0.11)$. We did not detect a difference in plasma and serum circulating metabolites between treatments except serum Met concentration and the ratio of lysine (Lys) to Met in cows with micronutrient supplementation was significantly $(P<0.05)$ higher and significantly $(P<0.05)$ lower than control cows on d 10 and 12 postpartum, respectively. Collectively, rumen-protected (RP)-Met, -choline and -betaine did not improve milk production performance and health of periparturient dairy cows. Further research is needed to explore the digestibility of encapsulated micronutrients in the rumen and their availability for intestinal absorption. 


\section{Introduction}

Dairy cows mobilize adipose tissue hydrolyzing TAG into NEFA and glycerol to meet energy demand when transitioning from gestation to lactation. High circulating NEFA results in the accumulation of hepatic lipid, which is associated with metabolic disease (Hammon et al., 2006), decreased milk production (Duffield et al., 2009) and poor reproductive performance (Walsh et al., 2007). Hence, fatty liver in periparturient dairy cows negatively impact producer profit margins. A possible reason for this phenomenon is the limited capability of ruminants to synthesize VLDL and export TAG from liver (Emery et al., 1992). Among a series of steps involved in VLDL synthesis, all of the lipid components including TAG, phospholipids, free cholesterol, and cholesterol ester are packaged with apoprotein (Apo) B-100 under the assistance of microsomal triacylglycerol transfer protein (MTTP) and the newly formed VLDL is moved outside the hepatocyte via secretary vesicles (White et al., 1998). Apoprotein B-100 will not be translocated into the lumen of endoplasmic reticulum without sufficient lipid components (White et al., 1998).

Additionally, the content of choline and phosphatidylcholine (PC) in plants is low and a significant portion of these nutrients undergo ruminal degradation, thus causing inadequate intestinal supply (Sharma and Erdman, 1989). A potential industry approach to alleviate fatty liver disease during the transition period is the supplementation of choline to elevate VLDL production in dairy cows (Piepenbrink and Overton, 2003; Guretzky et al., 2006). A study by Emmanuel and Kennelly (1984) found that $28 \%$ absorbed Met is utilized for choline synthesis and $6 \%$ of choline comes from Met. Circulating Met serves as a methyl donor and is involved in the synthesis of PC from phosphatidylethanolamine (PE). Additionally, betaine provides methyl groups that recycle homocysteine to Met. Hence, choline, Met, and betaine are closely related to 
phospholipid metabolism. Choline also contributes methyl groups to for the synthesis of carnitine, which is a required metabolite for the oxidation of long chain NEFA in the mitochondria. Choline can spare more Met that can be used for milk protein synthesis because Met is the first limiting amino acid (AA) required for milk protein production (NRC, 2001). In theory, these micronutrients should play a fundamental role in promoting production and hepatic health in dairy cows.

The individual supplementation of RP-Met, -choline and -betaine on milk production performance and health has been studied in periparturient dairy cows. For instance, supplementation of Met (0.04\% dry matter (DM)) elevated milk protein percentage and yield, milk fat yield, and energy-corrected milk (ECM) by $0.18 \%$, and $0.13 \mathrm{~kg} / \mathrm{d}, 0.18 \mathrm{~kg} / \mathrm{d}$, and 3.9 $\mathrm{kg} / \mathrm{d}$, respectively (Osorio et al., 2013). Elek et al. (2008) found that milk yield, milk protein and fat yield, and $3.5 \%$ fat-corrected milk (FCM) significantly increased by $4.4 \mathrm{~kg} / \mathrm{d}, 0.18 \mathrm{~kg} / \mathrm{d}$ and $0.1 \mathrm{~kg} / \mathrm{d}$, and $2.5 \mathrm{~kg} / \mathrm{d}$, respectively, following the addition of 25 and $50 \mathrm{~g} / \mathrm{d}$ of choline before and after calving. Guretzky et al. (2006) showed that $15 \mathrm{~g} / \mathrm{d}$ choline tended to increase TAG concentration in serum possibly due to increased VLDL production. Previous work evaluating the individual supplementation of RP-betaine in peripartal dairy cows is inadequate. However, one early-lactation study did suggest that choline has more of a beneficial effect on improving production and health performance as compared with Met and betaine supplementation (Davidson et al., 2008).

However, the combined effects of RP-Met, -choline and -betaine in peripartruient dairy cows are unknown. Therefore, the objective to our study was to investigate the effects on milk production performance and metabolic health. 


\section{Materials and methods}

\section{Experimental design and animal management}

Experimental procedures were approved by the Institutional Animal Care and Use Committee at West Virginia University (WVU) (Morgantown). Thirty multiparous ( $2^{\text {nd }}$ and $3^{\text {rd }}$ lactation) nonlactating pregnant Holstein cows were enrolled in a study completed at DoVan Farms, WVU Agricultural Research and Education Partner, and a 700-Holstein cow commercial dairy farm (Berlin, PA) from May, 2015 to September, 2015. Cows were individually housed in straw-bedded pens from - 28 d prepartrum through d 14 postpartum, and in a free-stall barn from d 15 through d 28 postpartum. When cows were in straw-bedded pens, they were fed the same diets with or without micronutrients ( $22 \mathrm{~g} / \mathrm{d}$ Met, $10 \mathrm{~g} / \mathrm{d}$ choline chloride, and $3 \mathrm{~g} / \mathrm{d}$ betaine). All cows received $65 \mathrm{~g} / \mathrm{d}$ of lipid encapsulate with $62 \%$ palmitic acid. Control and micronutrient supplementation groups were balanced by calving date and BCS $(3.48 \pm 0.10)$. Twenty-seven cows including 13 control cows and 14 micronutrient supplementation cows had been used throughout the experiment but three of them were removed from the experimental herd due to severe diseases (e.g. retained placenta). All cows were provided ad libitum access to prepartum or postpartum TMR that were formulated to meet nutrient recommendations (NRC, 2001). Cows were fed once and twice daily during pregnancy and lactation, respectively, and provided unrestricted access to water. Daily DM content was determined by drying at $60^{\circ} \mathrm{C}$ until a static weight for DMI record. Milk production was daily recorded from d 0 throughout 60 postpartum. Body weight and BCS were recorded weekly. Three trained individuals recorded BCS for all the cows by using a 1.0 to 5.0 scale that described in Wildman et al. (1982). Body condition score data were averaged for each cow at $\mathrm{d}-28,-14,-7,0,7,14$, and 28 , relative to (expected) calving. 


\section{Sample collection and analysis}

Weekly feed samples were collected and monthly composite feed samples were submitted to a commercial laboratory for nutrient composition analysis by wet chemistry (Cumberland Valley Analytical, Cumberland, MD; AOAC International, 1995; method 989.03). Ingredients and nutrient composition of the prepartrum and postpartum diets are provided in Table 3-1. Milk Samples were collected at each milking time daily on d 0 through 10, 14, 21, and 28 postpartum, and stored at $4^{\circ} \mathrm{C}$ until analysis. Milk samples were analyzed by midinfrared spectroscopy (Dairy One, Ithaca, NY) and analyzed for content of milk protein, fat, lactose, and TS, and milk urea nitrogen (MUN), and somatic cell count (SCC).

Blood samples were collected from the coccygeal vein prior to morning feeding on -28, $21,-14$, daily from -7 to $7,14,21,28$, relative to (expected) calving. Blood samples were also collected at 3, 6, 9 hours after morning feeding on d 10 and 12, postpartum. Plasma collection tubes were placed on ice for 30 min until centrifugation at $3,400 \mathrm{x}$ g for $10 \mathrm{~min}$. Serum collection tubes were allowed to clot for $30 \mathrm{~min}$ at room temperature before centrifugation at $3,400 \mathrm{x} \mathrm{g}$ for 10 min. Plasma and serum samples were snap-frozen in a liquid nitrogen tank immediately after collection and stored at $-80^{\circ} \mathrm{C}$ until further analysis.

Plasma samples were analyzed for NEFA, BHBA, glucose, insulin, TAG, total cholesterol, free cholesterol, and LDL-cholesterol at WVU. Plasma NEFA, BHBA, glucose, TAG, total cholesterol, free cholesterol and LDL-cholesterol concentrations were measured by enzymatic methods using commercial kits (HR Series NEFA-HR (2), Autokit 3-HB, Autokit Glucose, L-Type TAG M, Cholesterol E, and Free Cholesterol E, L-Type LDL-C, respectively; Wako Chemicals USA Inc., Richmond, VA). Plasma insulin concentration was measured by enzyme-linked immunosorbent assay (ELISA) using a commercial kit (Mercodia Bovine Insulin; 
Mercodia AB, Uppsala, Sweden). Intra- and inter-assay coefficient of variation (CV) were 3.2\% and $19.4 \%, 3.2 \%$ and $18.6 \%, 3.5 \%$ and $18.0 \%, 2.4 \%$ and $31.9 \%, 3.5 \%$ and $14.6 \%, 2.4 \%$ and $21.2 \%, 4.7 \%$ and $10.1 \%$, and, $4.2 \%$ and $9.9 \%$ for NEFA, BHBA, glucose, TAG, total cholesterol, free cholesterol, LDL, and insulin, respectively.

Serum samples were analyzed for total protein, albumin, globulin, and hemoglobin, and were used for determination of the profile of AA. Serum samples on d 5, 10 and 14 were sent to a commercial laboratory for serum proteins analysis by indirect potentiometry (Animal Health Diagnostic Center of Cornell University, Ithaca, NY). The profile of serum AA was quantified by using GC/MS/MS at WVU. The EZ:faastTM AA analysis kit (Phenomenex, Torrance, CA) was used and the operational procedure mentioned by Badawy et al. (2008) was followed by a laboratory technician in our lab.

Liver biopsies were conducted on $\mathrm{d}-28,5$, and 14 relative to (expected) calving as previously described (Jorritsma et al., 2001). In detail, the hair was clipped around the right $11^{\text {th }}$ intercostal space, iodine scrub was used to sanitize, $6 \mathrm{ml}$ of lidocaine $\mathrm{HCl}$ (Vedco Inc., Saint Joseph, MO) was injected through the skin, and iodine solution was rubbed again on the same area in about 10 mins. In our experiment, a fabricated trocar was utilized to collect approximately $1 \mathrm{~g}$ of liver samples for each cow per time point evaluated. Liver samples were used to determine the percentage of total lipid in liver as previously described by Starke et al. (2010).

\section{Calculations and Statistics}

Yields of 3.5\% FCM, ECM, and milk components were calculated using milk yield and components for each milking, summed for daily total, and averaged for each collection period. 
Concentrations of plasma cholesterol esters, and VLDL, and serum globulin were calculated using the following equations:

Cholesteryl esters $=$ total cholesterol - free cholesterol;

VLDL $=$ TAG/5; (Bauer, 1982)

Globulin $=$ total protein - albumin;

Data for DMI, milk yield, milk composition, plasma metabolites, serum proteins, concentrations of serum AA were analyzed under the MIXED model procedure of SAS (version 9.3; SAS Institute Inc., Cary, NC), according to the following model:

$$
\mathrm{Y}_{\mathrm{ijk}}=\mu+\mathrm{C}_{\mathrm{i}}+\mathrm{P}_{\mathrm{j}}+\mathrm{T}_{\mathrm{k}}+\left(\mathrm{P}_{\mathrm{j}} \times \mathrm{T}_{\mathrm{k}}\right)+\mathrm{e}_{\mathrm{ijk}}
$$

Where Yijk $=$ dependent variable, $\mu=$ overall mean, $\mathrm{Ci}=$ random effect of cow $(\mathrm{i}=1$ to $30), P j=$ fixed effect of sampling time ( $\mathrm{j}=-28$ to +28 , relative to calving), $\mathrm{Tk}=$ fixed effect of treatment $(\mathrm{k}=1$ to 2$), \mathrm{Pj} \times \mathrm{Tk}=$ interaction between sampling time and treatment, and eijk $=$ residual error. Normality of the residuals was checked with normal probability and box plots and homogeneity of variances with plots of residual versus predicted values. When necessary, data was logarithmic or reciprocal transformed for the right-skewed or left-skewed data. Data values were considered as outliers and removed from analysis when Studentized residuals were over |3.0|. Three common covariance structures (variance components, first-order autoregressive, compound symmetry) for repeated measures analysis were evaluated and the structure with the smallest Akaike's information criterion coefficient was selected for analysis. Preplanned contrast was used to compare the difference between two treatment groups at each time point. Significance was declared at $P<0.05$ and trends at $P<0.15$. All results are expressed as least squares means and their stand errors. 


\section{Results}

\section{Milk production responses}

Milk yield was not modified by treatment $(P=0.70)$ and average milk yield from d 0 throughout d 60 was $41 \mathrm{~kg} / \mathrm{d}$ (Figure 3-1); however, milk production was significantly $(P<0.001)$ increased as lactation progressed. Specifically, milk yield increased $91 \%$ within the first three days after calving. Milk protein percentage and yield decreased significantly $(P<0.001)$ as lactation advanced (Figure 3-2A and B). The highest milk protein percentage $(11.43 \%)$ and the highest milk protein yield $(2.11 \mathrm{~kg} / \mathrm{d})$ by cows were detected on $\mathrm{d} 0$. Milk protein percentage and yield declined by 76 and $45 \%$ between d 0 and 28 postpartum. An interaction of treatment by time affected milk protein yield as micronutrient supplementation significantly decreased milk protein yield on d $0(1.76$ vs. $2.46 \mathrm{~kg} / \mathrm{d} ; P<0.01)$. However, no treatment differences were observed for percentage and yield of milk protein $(P=0.90 ; P=0.43)$. Milk fat percentage and yield were significantly $(P<0.001)$ affected by day relative to parturition (Figure 3-2C and D). The values of milk fat percentage and yield increased by 24 and $124 \%$ within the first three days after calving, respectively. A tendency was observed for an interaction between treatment and time for milk fat yield $(P=0.08)$. Cows fed with micronutrient supplement tended $(P=0.08)$ to have lower milk fat yield than cows fed with control diet on d 28, whereas they displayed significantly $(P<0.01)$ higher milk fat yield on d 21 postpartum. All the other milk components including percentages and yield of milk lactose and TS, MUN, SCC, 3.5\% FCM, and ECM were significantly $(P<0.001)$ affected by day relative to parturition (Figure 3-2E-L). Milk TS

percentage tended to increase in cows supplemented with micronutrients across the experiment $(P=0.11)$. But, others were not impacted by treatment. A significant interaction between treatment and time was observed for milk lactose and TS yield $(P<0.05)$. Milk lactose yield in 
micronutrient supplementation group tended to be higher on d $1(P=0.11)$, whereas it was significantly $(P<0.05)$ lower on d 28 , relative to control group. In a similar manner, milk TS yield in cows supplemented with micronutrients had significantly $(P<0.05)$ higher value on $\mathrm{d}$ 21, although significantly $(P<0.05)$ lower on d 28 postpartum. There was a significant $(P<0.05)$ interaction observed for ECM as cows supplemented with micronutrients had higher value on d 21 but lower value on d 28 postpartum.

\section{Dry matter intake, body condition score, and body weight}

There was no difference for DMI between control and micronutrient supplement groups across the experiment $(P=0.39$; Figure $3-3)$. The average DMI prepartum and postpartum was 12.6 and $16.0 \mathrm{~kg} / \mathrm{d}$ respectively. Day relative to parturition affected DMI significantly $(P<$ 0.001). In this experiment, DMI slightly decreased by $22 \%$ prepartum and increased $48 \%$ within the first two weeks postpartum. Treatment had no effect on BCS and BW $(P=0.80$ and 0.18 respectively; Figure 3-4A and B), whereas, they were affected significantly by day relative to parturition $(P<0.001)$. Body condition score and BW decreased by 0.72 unit $(-20 \%)$ and $96 \mathrm{~kg}$ $(-14 \%)$ from $\mathrm{d}-28$ to $\mathrm{d} 28$ relative to parturition. There was a tendency for treatment by time interaction for BCS $(P=0.09)$.

\section{Metabolic responses}

Plasma metabolites including NEFA, BHBA, glucose, and insulin were significantly $(P<$ 0.001) influenced by day relative to parturition (Figure 3-5A-D). Circulating NEFA and BHBA increased during the transition from gestation to lactation (Figure 3-5A and 5B). Characteristic of the peripartal dairy cow, circulating glucose increased acutely at parturition and was lower 
postpartum (Figure 3-5C). Plasma insulin started to decrease two weeks before calving and was lower postpartum. For the interaction between treatment and day, a tendency for significance was observed for plasma glucose $(P=0.13)$ and significance was detected for circulating insulin $(P<0.05)$. Although cows with micronutrient supplementation had significantly higher glucose on -1 d prepartum, they tended to have lower glucose on d 0 and 1, compared to control cows. As for insulin concentration, cows supplemented with micronutrients had significantly higher value than cows supplemented without micronutrients on $\mathrm{d}-21(P<0.001)$. Additionally, treatment had no effect on modifying plasma NEFA, BHBA, glucose, or insulin.

Plasma TAG, total cholesterol, free cholesterol, cholesterol ester, estimated VLDL and LDL-cholesterol were significantly $(P<0.001)$ affected by day relative to parturition (Figure 36A-F). Plasma circulating TAG decreased by $71 \%$ across the experiment. Estimated VLDL shared exactly the same pattern with the response to plasma TAG. All cholesterol components including total cholesterol, free cholesterol and cholesterol esters changed with the same pattern. Plasma LDL-cholesterol decreased by $46 \%$ from d -28 to $7 \mathrm{~d}$ after calving and increased by $104 \%$ during the second week of lactation. No effect of treatment or interaction between treatment and time was observed for TAG, cholesterol components, VLDL, or LDL-cholesterol in the blood.

Day relative to parturition significantly $(P<0.001)$ impacted the values of total protein and globulin, as well as the ratio of albumin to globulin (Figure 3-7A-E). Serum circulating total protein and globulin increased by $63 \%$ and $20 \%$ between d 5 and 14 postpartum. The ratio between albumin and globulin decreased by $19 \%$ when comparing d 5 and 14 relative to calving. We did not observe any treatment or interaction of treatment by time for all serum proteins analyzed. 
Concentrations of AA in serum were not be modified by treatment except Met (Table 32). Serum cysteine (Cys) in cows supplemented with micronutrients tended to be higher than non-supplemented cows $(P<0.09)$. Additionally, the ratio of Lys to Met was significantly $(\mathrm{P}<$ 0.05) lower in the micronutrient supplementation group, as compared with control group.

Day relative to parturition had a significant $(P<0.001)$ effect on percentage of liver lipid (Figure 3-8). In our study, liver lipid percentage was elevated by $135 \%$ from $-28 \mathrm{~d}$ to $14 \mathrm{~d}$ relative to calving. Treatment and interaction of treatment by time did not modify the liver lipid percentage $(P=0.61, P=0.24$; respectively).

\section{Discussion}

To the best of our knowledge, the effects of combined RP-Met, -choline, and -betaine supplementation in peripartal dairy cows have not been studied previously; however, the effects of supplementation of these micronutrients have been individually investigated (Guretzky et al., 2006; Davidson et al., 2008; Osorio et al., 2013). Variances in results might be caused by study designs including lengths of supplementation, doses of supplements, stages of lactation cycle, milk production merit, and characteristics of products such as protection technology and palatability. The digestibility of these micronutrients in the rumen was not tested in the present study.

Our results showed that micronutrient supplementation did not affect milk production or dairy cow health. In spite of this observation, this study detected multiple physiological modifications in dairy cows as they transition from gestation to lactation. The high elevation (91\%) of milk yield after calving proved that cows have the capacity to elevate their milk 
production dramatically within the first few days of lactation, which represents an increase in energy demand to support lactation.

Among previous RP-Met studies evaluating the peripartal dairy cow, milk yield responses are inconsistent. For instance, there was no effect of Met (17 g/d; 0.12 and 0.19\% or 0.04 and $0.06 \%$ of ration DM prepartum and postpartum) on modifying milk yield in studies performed by Overton et al. (1996) and Ordway et al. (2009). In contrast, the addition of RP-Met (0.04\% ration $\mathrm{DM}$ ) from $21 \mathrm{~d}$ before to $30 \mathrm{~d}$ after calving had the tendency to increase milk yield by $3.4 \mathrm{~kg} / \mathrm{d}$ when compared with a control diet (Osorio et al., 2013). Furthermore, Lara et al. (2006) observed milk production increased by $4.4 \mathrm{~kg} / \mathrm{d}$ when early lactation cows were supplemented with RP-Met (16 g/d). Several earlier RP-choline studies have demonstrated that the supplementation $(15 \mathrm{~g} / \mathrm{d})$ did not affect milk yield when supplemented in the transition period (Guretzky et al., 2006; Zom et al., 2011). However, periparturient dairy cows with choline supplementation $(20 \mathrm{~g} / \mathrm{d} ; 25$ and $50 \mathrm{~g} / \mathrm{d}$, prepartum and pospatrum, respectively) produced 2.9, and $4.4 \mathrm{~kg}$ more milk daily when compared with cows without choline supplementation, respectively (Pinotti et al., 2003; Elek et al., 2008). Besides, the evaluation of dairy cows in early lactation (32-102 DIM) by Suksombat et al. (2011) detected that per gram of choline supplemented per day, milk yield increased by 40 or $25 \mathrm{~g} / \mathrm{d}$ when supplemented between 20 to $40 \mathrm{~g} / \mathrm{d}$. The highest efficiency of supplementation for increasing milk yield during early lactation might be obtained at $20 \mathrm{~g} / \mathrm{d}$ choline (Piepenbrink and Overton, 2003; Suksombat et al., 2011). No research on the effects of RP-betaine in the periparturiant dairy cows has been found.

Being consistent with our results, one former study by Overton et al. (1996) did not find any change for milk protein percentage and yield with the supplementation of $17 \mathrm{~g} / \mathrm{d}$ Met from 1 week before to 18 week after calving. However, several studies have demonstrated that the 
supplementation of RP-Met ( 0.12 and $0.19 \%$ or 0.04 and $0.06 \%$ for prepartum and postpartum; $0.04 \%$ of ration DM, respectively) significantly increased milk protein percentage by $0.15 \%$ and 0.18\%, during the transition period (Ordway et al., 2009; Osorio et al., 2013). These increased milk protein percentages might contribute to circulating Met is the first limiting AA for milk protein synthesis (NRC, 2001). In agreement with our results, no effects of RP-choline supplementation on milk protein percentage and yield were observed during the transition period (Hartwell et al., 2000; Piepenbrink and Overton, 2003; Pinotti et al., 2003; Zahra et al., 2006; Davidson et al., 2008). Choline supplemented in these studies ranged from $6 \mathrm{~g} / \mathrm{d}$ to $75 \mathrm{~g} / \mathrm{d}$. In spite of these findings, Elek et al. (2008) found a tendency for increased milk protein percentage, and significantly elevated milk protein yield $(0.18 \mathrm{~kg} / \mathrm{d})$. Indeed, choline supplementation spares Met so this limiting AA can be utilized for milk protein synthesis (Emmanuel et al., 1984). Previous work in early- and mid-lactation dairy cows demonstrated that betaine does not modify milk protein percentages and yields (Davidson et al., 2008; Wang et al., 2010; Zhang et al., 2014). In comparison, milk protein concentration was significantly decreased by $0.07 \%$ with betaine supplementation in early-lactation (25, 50, and $100 \mathrm{~g} / \mathrm{d}$ ) (Peterson et al., 2012). The reason for decreased milk protein percentage is still unknown.

Studies evaluating Met $(17 \mathrm{~g} / \mathrm{d} ; 0.12$ and $0.19 \%$ or 0.04 and $0.06 \%$ of ration DM prepartum and postpartum) supplementation, including our study (22 g/d Met), have not observed beneficial changes in milk fat concentration and yield (Overton et al., 1996; Ordway et al., 2009). However, Osorio et al. (2013) reported that milk fat yield was increased by $0.18 \mathrm{~kg} / \mathrm{d}$ under the supplementation of Met ( $0.04 \%$ ration DM). Methionine might be essential for the synthesis of hepatic-derived VLDL since it contributes methyl groups for the synthesis of PC (McCarthy et al., 1968). More lipids carried by VLDL to the mammary gland may increase fatty 
acid availability for milk fat TAG incorporation; however, this response is controlled by the action of lipases (Ha and Lindsay, 1993). Yields and concentrations of milk fat were not altered in periparturient dairy cows during the supplementation of RP-choline (Hartwell et al., 2000; Xu et al., 2006; Guretzky et al., 2006; Zahra et al., 2006). However, three studies performed by Piepenbrink and Overton, (2003), Pinotti et al. (2003), and Elek et al. (2008) reported that increased milk fat yield when choline (20 to $75 \mathrm{~g} / \mathrm{d}$ ) was supplemented during the transition period, a response that was accompanied by increased milk yields. Choline can be synthesized into PC within VLDL directly and might promote the production of VLDL. Comparable to the evaluation of choline, betaine ( $45 \mathrm{~g} / \mathrm{d})$ supplementation during early lactation did not modify the yield and concentration of milk fat when compared to an unsupplemented diet (Davidson et al., 2008). In theory, RP-Met, -choline and -betaine have the potential to increase milk fat synthesis by increasing substrate availability; however, this is in contrast to the current state of the literature suggesting.

No effect of treatment on DMI was observed in our study, a response comparable to others (Overton et al., 1996). This observation is a result of non-distinctive milk yield and BCS between two groups. In contrast, Osorio et al. (2013) found that Met supplementation (0.04\% of ration DM) was associated with an increase in postpartum DMI. Consistent with the results of our study, previous research has not observed changes in DMI with the supplementation of choline either prepartum or postpartum (Hartwell, et al. 2000; Piepenbrink and Overton, 2003; Guretzky, et al. 2006; Elek, et al. 2008). The amount of supplemented choline in these studies ranged from 6 to $75 \mathrm{~g} / \mathrm{d}$. Likewise, several studies investigating betaine supplementation showed that no change in DMI in early- and mid-lactation (Davidson et al., 2008, Wang et al., 2010; Peterson et al., 2012). 
In our study, micronutrient supplementation did not alter BCS, results that are comparable to the sole supplementation of Met in peripartal dairy cows (Overton et al., 1996; Ordway et al., 2009). In contrast, Osorio et al. (2013) observed that Met supplementation tended to lower BCS $(P=0.11)$ after calving while had no effect on prepartum BCS. The increased milk yield with RP-Met (0.04\% ration DM) enhanced the lipolysis of adipose tissue in Osorio et al. (2013). The unaltered BW in our study was in line with observations by Ordway et al. (2009) and Osorio et al. (2013). In contrast, Overton et al. (1996) reported that there was a tendency for cows fed RP-Met $(17 \mathrm{~g} / \mathrm{d})$ to have a greater BW than non-supplementation. The amounts of Met added in previous research are around $15 \mathrm{~g} / \mathrm{d}$. However, supplemental choline $(15 \mathrm{~g} / \mathrm{d})$ had the tendency $(P=0.12)$ to decrease BW loss (Guretzky et al., 2006). This might be explained by reduced the mobilization of body tissue with supplementation of choline postpartum (Soltan et al., 2012). The effects of betaine supplementation on BCS change during the peripartum has not been previously investigated.

During the transition from gestation to lactation, dairy cows mobilize TAG in adipose tissue to meet energy demand. In agreement with the present study, several studies investigating periparturient dairy cows reported that RP-choline (15-75 g/d) had no effect on reducing plasma NEFA concentration (Piepenbrink and Overton, 2003; Pinotti et al., 2003; Janovick Guretzky et al., 2006). However, supplementation with choline ( $20 \mathrm{~g} / \mathrm{d})$ has been shown to decrease circulating NEFA at calving (Pinotti et al., 2003). Concentration of plasma BHBA represents the degree of incomplete oxidation of NEFA in the liver and is an indicator of ketosis. Results in the current study were in line with observations in previous studies that RP-choline supplementation is not capable of altering BHBA concentration in periparturient dairy cows (Pinotti et al., 2003; Zom et al., 2011). The choline supplemented might be used for the synthesis of VLDL first and 
then for carnitine synthesis. Carnitine is a metabolite involved into the oxidation of NEFA in the liver. Piepenbrink and Overton (2003) reported that a lower concentration of BHBA in cows fed 60g/d RP-choline on 28 DIM, relative to cows without supplementation. The sharp elevation in glucose concentration around calving is due to increased conversion from glucogenic AA, glycerol and propionate to glucose in the liver during the first week after calving (Overton et al., 1998). Comparable to the current results, several former studies did not report any effect of RPcholine on altering circulating glucose concentration (Pinotti et al., 2003; Janovick Guretzky et al., 2006)

Like the present study, circulating TAG and VLDL in blood decreased between $\mathrm{d}-14$ to $\mathrm{d}$ 14 relative to parturition (Osorio et al., 2013). The decreased concentrations of TAG and VLDL in blood are caused by the accumulation of TAG in the liver while transitioning from prepartum to postpartum (den Top et al., 1996). Previously, serum TAG in early lactation cows has not been modified by micronutrient supplementations (20 g/d RP-Met, 40 g/d RP-choline or 45 g/d RPbetaine) in Davidson et al. (2008), comparable to our study. The elevation on concentrations of these three cholesterol components might be explained by increased plasma LDL after calving in the present study. Plasma TAG is in high demand for periparturient dairy cows, which probably lead to a high production of LDL. Our results are in agreement with observations in periparturient dairy cow studies that plasma level of cholesterol could not be impacted by RPcholine supplementation (Pinotti et al., 2003). In contrast, one study in the transition period by Zahra et al. (2006) reported that supplementation with $56 \mathrm{~g} / \mathrm{d}$ RP-choline lowered serum cholesterol concentrations.

Beside the utilization in peripheral tissues and mammary gland, circulating NEFA can be converted into TAG, carbon dioxide $\left(\mathrm{CO}_{2}\right)$, energy or ketone bodies. In our study, the incidence 
of fatty liver in periparturient dairy cows increased as lactation advanced. The high liver lipid percentage results at d 14 can be explained by increased plasma NEFA concentration in the transition period. Comparable to our results, two previous studies did not report any effect of RPcholine on concentrations of liver TAG (Piepenbrink and Overton, 2003; Zahra et al., 2006). However, Zom et al. (2011) observed lower liver TAG concentration when choline was supplemented at $14.4 \mathrm{~g} / \mathrm{d}$ from 21 to 42 DIM.

Albumin and globulin are parts of globular proteins produced in the liver and immune system. Furthermore, hemoglobin in red blood cells functions as an oxygen transporter. These serum protein fractions are evaluated to assess health in dairy cows. In our study, we observed a $20 \%$ elevation in globulin from d 5 to d 14 suggesting that cows might be under stress due to negative energy balance (NEB). Reid et al. (1983) showed that low concentration of albumin was associated with fatty liver. However, albumin concentration did not change as lactation advanced in the present study. The increased total protein concentration and deceased ratio of albumin to globulin were results of increased globulin and unchanged albumin levels in blood.

In this study, we did not observe an evident improvement in milk production performance or cow health. One probable explanation is the over-protection of micronutrients in the gastrointestinal tract because a certain amount of supplementation in feces was observed during the experiment. Besides, this may be caused by short supplementation period, insufficient amounts supplement and possible physiological difference in cows. Testing the digestibility of micronutrients and their intestinal absorption is necessary. 


\section{Conclusion}

Our results demonstrate that Met, choline and betaine (22, 10, and $3 \mathrm{~g} / \mathrm{d}$ respectively) supplementation did not improve milk production performance or health in periparturient dairy cows. We did observe a sharp increase in circulating NEFA and BHBA, a dramatic decrease in plasma insulin and glucose concentrations in cows transitioning from gestation to lactation. Our study showed that the decline in VLDL and TAG in blood occurred in parallel with the development of fatty liver disease. Further research is needed to study the rumen digestibility and intestinal absorption of these micronutrients. 


\section{Literature Cited}

Badawy, A. B., C. J. Morgan, and J. A. Turner. 2008. Application of the Phenomenex EZ: faast ${ }^{\mathrm{TM}}$ amino acid analysis kit for rapid gas-chromatographic determination of concentrations of plasma tryptophan and its brain uptake competitors. N.A. Acid. 34, no. 4 (2008): 587-596.

Davidson, S., B. A. Hopkins, J. Odle, C. Brownie, V. Fellner, and L. W. Whitlow. 2008. Supplementing limited methionine diets with rumen-protected methionine, betaine, and choline in early lactation Holstein cows. J. Dairy Sci. 91:1552-1559.

den Top, Van, A. Marc, Math JH Geelen, Theo Wensing, and G. Henk Wentink. 1996. Higher postpartum hepatic triacylgylcerol concentrations in dairy cows with free rather than restricted access to feed during the dry period are associated with lower activities of hepatic glycerolphosphate acyltransferase. J. Nutr. 126:76.

Duffield, T. F., K. D. Lissemore, B. W. McBride, and K. E. Leslie. 2009. Impact of hyperketonemia in early lactation dairy cows on health and production. J. Dairy Sci. 92:571-580.

Elek, P., J. R. Newbold, T. Gaal, L. Wagner, and F. Husveth. 2008. Effects of rumen-protected choline supplementation on milk production and choline supply of periparturient dairy cows. Anim. 2:1595-1601.

Emery, R. S., J. S. Liesman, and T. H. Herdt. 1992. Metabolism of Long Chain Fatty Acids by Ruminant Liver1. J. Nutr. 122:832.

Emmanuel, B. and J. J. Kennelly. 1984. Kinetics of methionine and choline and their incorporation into plasma lipids and milk components in lactating goats. J. Dairy Sci. 63:1912-1918.

Guretzky, N., A. Janovick, D. B. Carlson, J. E. Garrett, and J. K. Drackley. 2006. Lipid metabolite profiles and milk production for Holstein and Jersey cows fed rumenprotected choline during the periparturient period. J. Dairy Sci. 89:188-200.

Ha, J. K., and R. C. Lindsay. 1993. Release of volatile branched-chain and other fatty acids from ruminant milk fats by various lipases. J. Dairy Sci. 76:677-690.

Hammon, D. S., I. M. Evjen, T. R. Dhiman, J. P. Goff, and J. L. Walters. 2006. Neutrophil function and energy status in Holstein cows with uterine health disorders. Vet. Immunol. N. Immunopathol. 113:21-29.

Hartwell, J. R., M. J. Cecava, and S. S. Donkin. 2000. Impact of dietary rumen undegradable protein and rumen-protected choline on intake, peripartum liver triacylglyceride, plasma metabolites and milk production in transition dairy cows. J. Dairy Sci. 83:2907-2917. 
Jorritsma, R., H. Jorritsma, Y. H. Schukken, P. C. Bartlett, Th Wensing, and G. H. Wentink. 2001. Prevalence and indicators of post partum fatty infiltration of the liver in nine commercial dairy herds in The Netherlands. Livest. Prod. Sci. 68:53-60.

Lara, A., G. D. Mendoza, L. Landois, R. Barcena, M. T. Sánchez-Torres, R. Rojo, J. Ayala, and S. Vega. 2006. Milk production in Holstein cows supplemented with different levels of ruminally protected methionine. Livest. Sci. 105:105-108.

McCarthy, R. D., G. A. Porter, and L. C. Griel Jr. 1968. Bovine ketosis and depressed fat test in milk: a problem of methionine metabolism and serum lipoprotein aberration. J. Dairy Sci. 51:459-462.

NRC. 2001. Nutrient Requirements of Dairy Cattle. 7th rev. ed. Natl. Acad. Sci., Washington, DC.

Ordway, R. S., S. E. Boucher, N. L. Whitehouse, C. G. Schwab, and B. K. Sloan. 2009. Effects of providing two forms of supplemental methionine to periparturient Holstein dairy cows on feed intake and lactational performance. J. Dairy Sci. 92:5154-5166.

Osorio, J. S., P. Ji, J. K. Drackley, D. Luchini, and J. J. Loor. 2013. Supplemental Smartamine M or MetaSmart during the transition period benefits postpartal cow performance and blood neutrophil function. J. Dairy Sci. 96:6248-6263.

Overton, T. R., D. W. LaCount, T. M. Cicela, and J. H. Clark. 1996. Evaluation of a ruminally protected methionine product for lactating dairy cows." J. Dairy Sci. 79:631-638.

Peterson, S. E., P. Rezamand, J. E. Williams, W. Price, M. Chahine, and M. A. McGuire. 2012. Effects of dietary betaine on milk yield and milk composition of mid-lactation Holstein dairy cows. J. Dairy Sci. 95:6557-6562.

Piepenbrink, M. S. and T. R. Overton. 2003. Liver metabolism and production of cows fed increasing amounts of rumen-protected choline during the periparturient period. J. Dairy Sci. 86:1722-1733.

Pinotti, L., A. Baldi, I. Politis, R. Rebucci, L. Sangalli, and V. Dell'Orto. 2003. Rumen-Protected Choline Administration to Transition Cows: Effects on Milk Production and Vitamin E Status. J. Vet. Med. Ser. A. 50:18-21.

Reid, I. M., G. J. Rowlands, A. M. Dew, R. A. Collins, C. J. Roberts, and R. Manston. 1983. The relationship between post-parturient fatty liver and blood composition in dairy cows. J. Agric. Sci. 101:473-480.

Sharma, B. K. and R. A. Erdman. 1989. In Vitro Degradation of Choline from Selected Foodstuffs and Choline Supplements 1, 2. J. Dairy Sci. 72:2772-2776. 
Soltan, M. A., A. M. Mujalli, M. A. Mandour, and M. El-Shinway Abeer. 2012. Effect of dietary rumen protected methionine and/or choline supplementation on rumen fermentation characteristics and productive performance of early lactating cows. Pak. J. Nutr. 11:221.

Suksombat, W., R. Mirattanaphrai, and P. Paengsai. 2011. Performance of lactating dairy cows in response to supplementation of rumen-protected choline. J. Anim. Vet. Adv. 10:33213327.

Walsh, R. B., J. S. Walton, D. F. Kelton, S. J. LeBlanc, K. E. Leslie, and T. F. Duffield. 2007. The effect of subclinical ketosis in early lactation on reproductive performance of postpartum dairy cows. J. Dairy Sci. 90:2788-2796.

Wang, C., Q. Liu, W. Z. Yang, J. Wu, W. W. Zhang, P. Zhang, K. H. Dong, and Y. X. Huang. 2010. Effects of betaine supplementation on rumen fermentation, lactation performance, feed digestibilities and plasma characteristics in dairy cows." J. Agric. Sci. 148:487-495.

White, D. A., A. J. Bennett, M.A. Billett, and A. M. Salter. 1998. The assembly of triacylglycerol-rich lipoproteins: an essential role for the microsomal triacylglycerol transfer protein." Br. J. Nutr. 80:219-229.

Wildman, E. E., G. M. Jones, P. E. Wagner, R. L. Boman, H. F. Troutt, and T. N. Lesch. 1982. A dairy cow body condition scoring system and its relationship to selected production characteristics. J. Dairy Sci. 65:495-501.

Xu, G. Z., J. Ye, J. X. Liu, and Y. Y. Yu. 2006. Effect of rumen-protected choline addition on milk performance and blood metabolic parameters in transition dairy cows. Asian Australas. J. Anim. Sci. 19:390.

Zahra, L. C., T. F. Duffield, K. E. Leslie, T. R. Overton, D. Putnam, and S. J. LeBlanc. 2006. Effects of rumen-protected choline and monensin on milk production and metabolism of periparturient dairy cows. J. Dairy Sci. 89:4808-4818.

Zhang, L., S. J. Ying, W. J. An, H. Lian, G. B. Zhou, and Z. Y. Han. 2014. Effects of dietary betaine supplementation subjected to heat stress on milk performances and physiology indices in dairy cow. Genet. N. Mol. Res. 13:7577-7586.

Zom, R. L. G., J. Van Baal, R. M. A. Goselink, J. A. Bakker, M. J. De Veth, and A. M. Van Vuuren. 2011. Effect of rumen-protected choline on performance, blood metabolites, and hepatic triacylglycerols of periparturient dairy cattle. J. Dairy Sci. 94:4016-4027. 


\section{TABLES AND FIGURES}

Table 3-1: Ingredients and nutrient composition of experimental diets supplemented with or without micronutrient (rumen-protected methionine, choline and betaine) supplementation.

\begin{tabular}{lcc}
\hline & \multicolumn{2}{c}{ Diets } \\
\cline { 2 - 3 } Ingredients, \% of & Dry Period & Lactation Period \\
\hline Corn Silage & 35.89 & 43.06 \\
Grass Haylage & 27.26 & 6.41 \\
Grass Hay & 14.7 & 3.13 \\
Witmer Mix & 16.14 \\
Ground Corn & - & 15.74 \\
Dry Cow Mix & - & - \\
Soybean Meal & 14.33 & 6.14 \\
Cottonseed & 7.82 & 4.47 \\
Rennaissance Mix & - & 4.31 \\
Palmit Fat & - & 0.5 \\
Rumensin & - & 0.1 \\
& - & \\
Nutrient & & \\
Composition & & 49.08 \\
DM, \% & 45.73 & 16.57 \\
CP, \% of DM & 15.38 & 35.42 \\
NDF, \% of DM & 47.74 & 21.65 \\
ADF, \% of DM & 29.65 & 39 \\
NFC, \% of DM & 27.45 & 7.24 \\
Ash, \% of DM & 8.82 & \\
\hline
\end{tabular}

${ }^{1}$ Mix contained $28.0 \%$ citrus pulp, $30.3 \%$ soybean meal $47.5 \%, 18.7 \%$ distillers, $9.3 \%$ soy hulls, $3.3 \%$ calcium carbonate, $3.7 \%$ sodium bicarbonate, $2.3 \%$ urea, $2.3 \%$ fat, $2.1 \%$ salt, $0.3 \%$ biotin 640.

${ }^{2}$ Mix contained $24.9 \%$ soybean meal $47.5 \%, 23.2 \%$ ground corn, $16.6 \%$ corn distillers, $12,4 \%$ animate, $10.4 \%$ calcium carbonate, $9.1 \%$ selenium yeast, $2.5 \%$ calcium sulfate, and $<1 \%$ of each of the following: biophos, selenium yeast, and Vitamin E.

${ }^{3}$ Mix contained $43.6 \%$ fermenten, $21.8 \%$ calcium carbonate, $13.5 \%$ soybean hulls, $7.8 \% 1965$ mill mix 4 mintrex, $5.2 \%$ blood meal, $3.5 \%$ magnesium oxide, $2.6 \%$ celmanax, and $<1 \%$ of each of the following: Vitamin E, selenium $0.06 \%$, and 9273 selenium yeast 600 . 
Table 3-2: Serum amino acids responses to micronutrient supplementation (rumen protected methionine, choline, and betaine)

\begin{tabular}{|c|c|c|c|c|c|c|c|c|c|}
\hline \multirow[b]{2}{*}{ Item } & \multicolumn{2}{|c|}{$\operatorname{LSM}(\mathrm{d} 10)$} & \multirow[b]{2}{*}{ SEM } & \multicolumn{2}{|c|}{$\operatorname{LSM}(\mathrm{d} 12)$} & \multirow[b]{2}{*}{ SEM } & \multicolumn{3}{|c|}{$P$-value } \\
\hline & Control $^{1}$ & Mecovit $^{1}$ & & Control $^{1}$ & Mecovit $^{1}$ & & Treatment & Time & $\begin{array}{c}\text { Treatment } \\
\times \text { Time }\end{array}$ \\
\hline \multicolumn{10}{|l|}{ EAA } \\
\hline Val & 240.7 & 210.6 & 13.2 & 220 & 218.3 & 13.2 & 0.36 & 0.41 & $0.08 \dagger$ \\
\hline Leu & 168.1 & 140 & 9.7 & 154.7 & 147.2 & 9.7 & 0.17 & 0.53 & $0.04^{*}$ \\
\hline lle & 152.7 & 133.4 & 9.2 & 138.5 & 135.9 & 9.2 & 0.36 & 0.26 & $0.11 \dagger$ \\
\hline Thr & 46.4 & 45.1 & 3.8 & 43.3 & 44.7 & 3.8 & 0.99 & 0.37 & 0.5 \\
\hline Met & $11.1^{\mathrm{b}}$ & $13^{\mathrm{a}}$ & 0.9 & $8.6^{\mathrm{b}}$ & $11.6^{\mathrm{a}}$ & 1 & $0.04 *$ & $0.02 *$ & 0.48 \\
\hline Phe & 54.1 & 48.9 & 2.1 & 51.9 & 51.8 & 2.1 & 0.34 & 0.82 & 0.1 \\
\hline Lys & 92.7 & 82.6 & 4.9 & 87.7 & 85 & 4.9 & 0.28 & 0.74 & 0.34 \\
\hline His & 53.7 & 54 & 2.6 & 51.7 & 54.4 & 2.6 & 0.66 & 0.65 & 0.52 \\
\hline Trp & 30.4 & 27.9 & 1.7 & 29.3 & 29.7 & 1.7 & 0.61 & 0.78 & 0.2 \\
\hline $\begin{array}{l}\text { Total } \\
\text { EAA }\end{array}$ & 850 & 755.6 & 36.7 & 786 & 778.8 & 36.7 & 0.29 & 0.37 & $0.06 \dagger$ \\
\hline \multicolumn{10}{|l|}{ NEAA } \\
\hline Ala & 162.7 & 168.6 & 11.8 & 162 & 171.3 & 11.8 & 0.63 & 0.87 & 0.79 \\
\hline Sar & 13.7 & 14.5 & 0.7 & 13.9 & 13.8 & 0.7 & 0.73 & 0.62 & 0.39 \\
\hline Gly & 484.5 & 442.2 & 25.5 & 481 & 435 & 25.5 & 0.19 & 0.7 & 0.89 \\
\hline Ser & 77.1 & 82.5 & 6.4 & 79 & 79.2 & 6.4 & 0.74 & 0.81 & 0.37 \\
\hline Pro & 76.2 & 72 & 3.2 & 74.4 & 72.2 & 3.2 & 0.44 & 0.68 & 0.63 \\
\hline Asn & 35.7 & 36.8 & 2 & 35.2 & 36.6 & 2 & 0.66 & 0.76 & 0.9 \\
\hline Asp & 2.8 & 3.3 & 0.2 & 2.6 & 2.7 & 0.3 & 0.39 & $0.13 \dagger$ & 0.56 \\
\hline Glu & 29.3 & 30.4 & 2.3 & 25.8 & 28.9 & 2.2 & 0.48 & $0.09 \dagger$ & 0.48 \\
\hline Gln & 193.6 & 186.4 & 13.2 & 173.9 & 175.6 & 13.2 & 0.84 & 0.24 & 0.72 \\
\hline Tyr & 31.8 & 29.7 & 1.9 & 31.9 & 33.2 & 1.9 & 0.88 & 0.18 & 0.19 \\
\hline Cys & 13.4 & 13.8 & 0.62 & 13.2 & 14 & 0.64 & $0.09 \dagger$ & 0.9 & 0.46 \\
\hline $\begin{array}{l}\text { Total } \\
\text { NEAA }\end{array}$ & 1197.8 & 1158.4 & 40.3 & 1165 & 1169.3 & 40.3 & 0.73 & 0.68 & 0.42 \\
\hline $\begin{array}{l}\text { Total } \\
\text { AA }\end{array}$ & 2047.9 & 1914 & 66.4 & 1950.9 & 1915.3 & 66.4 & 0.31 & 0.29 & 0.28 \\
\hline Lys:Met & 9.5 & 6.8 & 0.9 & 9.8 & 8.5 & 0.9 & $0.04 *$ & 0.23 & 0.42 \\
\hline
\end{tabular}

Values are presented as LS Means \pm SEM; Unit is $\mu \mathrm{m} ; *, P<0.05 ; \dagger, P<0.15$.

${ }^{1}$ Treatments were control and mecovit ( $22 \mathrm{~g} / \mathrm{d}$ Met, $10 \mathrm{~g} / \mathrm{d}$ choline chloride, $3 \mathrm{~g} / \mathrm{d}$ betaine); all cows received $65 \mathrm{~g} / \mathrm{d}$ of lipid encapsulate with $62 \%$ palmitic acid. 
$\rightarrow$ Control $\triangle$ Mecovit

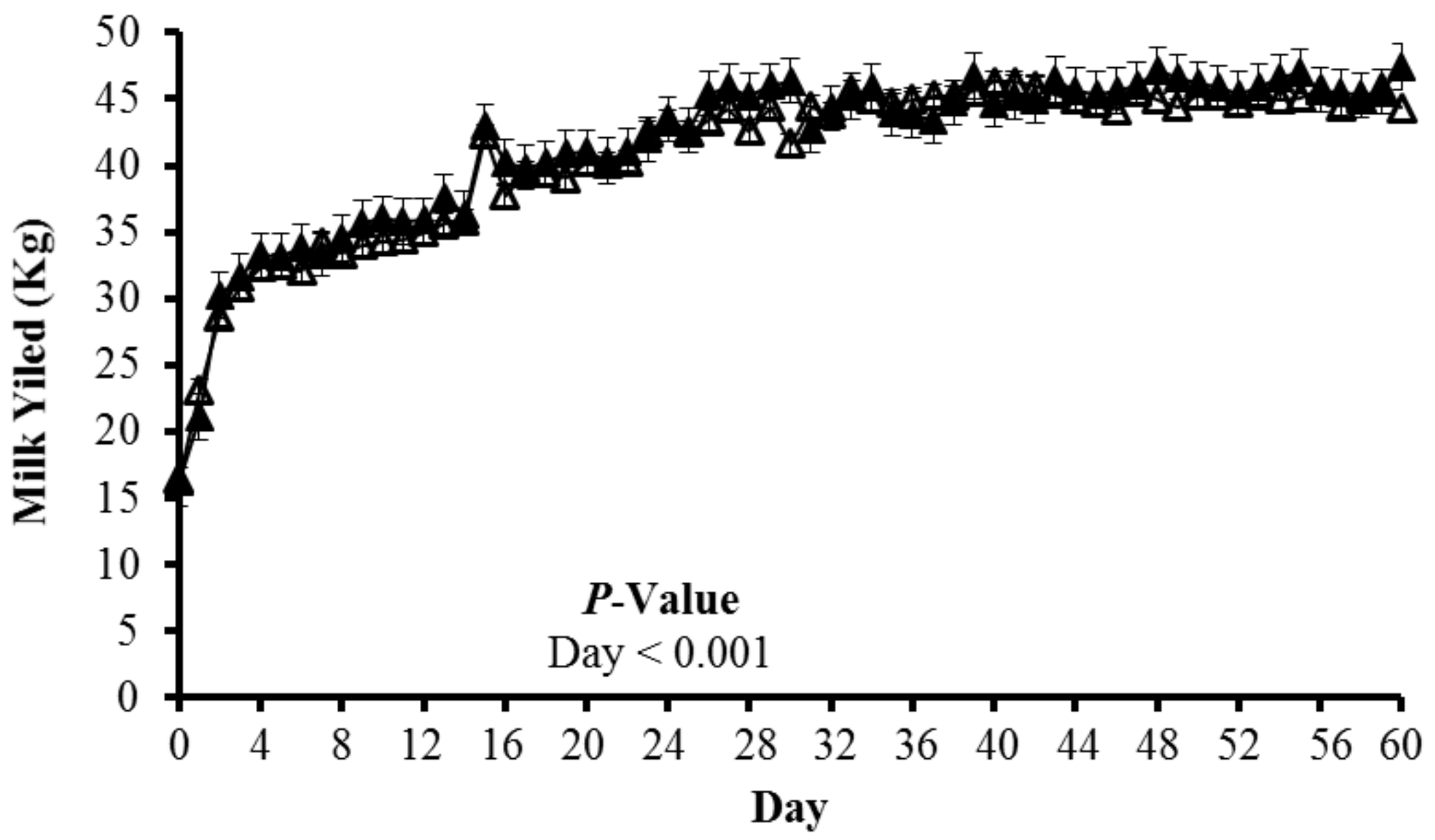

Figure 3-1: Milk yield responses to diets with or without micronutrient supplementation in the first two months of lactation. Data are least squares means and their standard errors. 
- Control $\triangle$ Mecovit

A

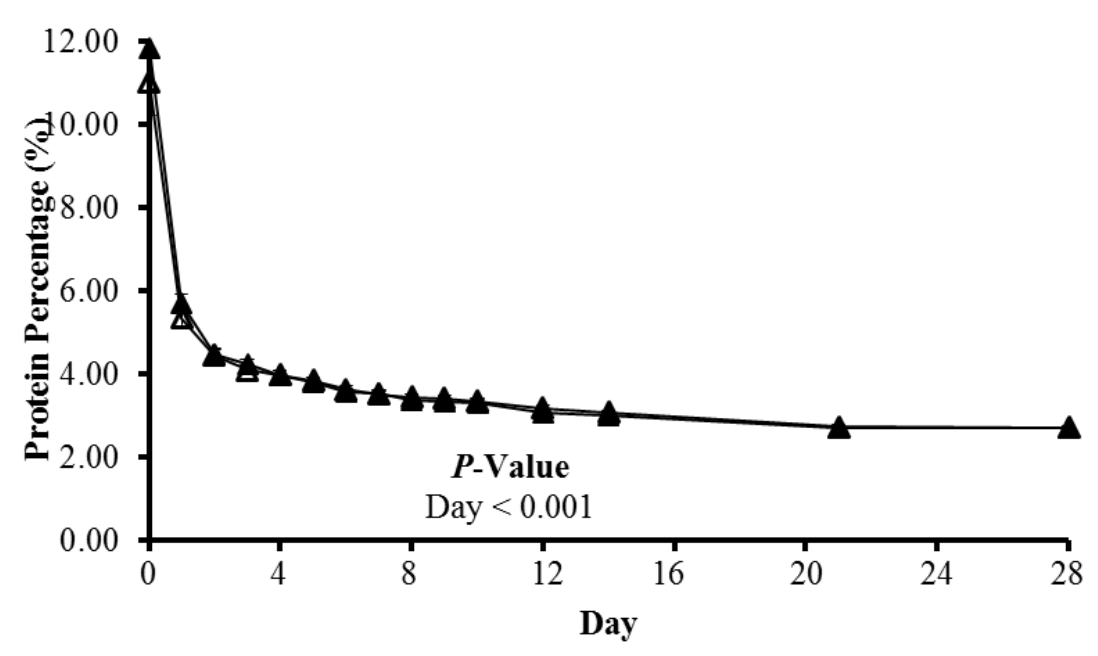

C

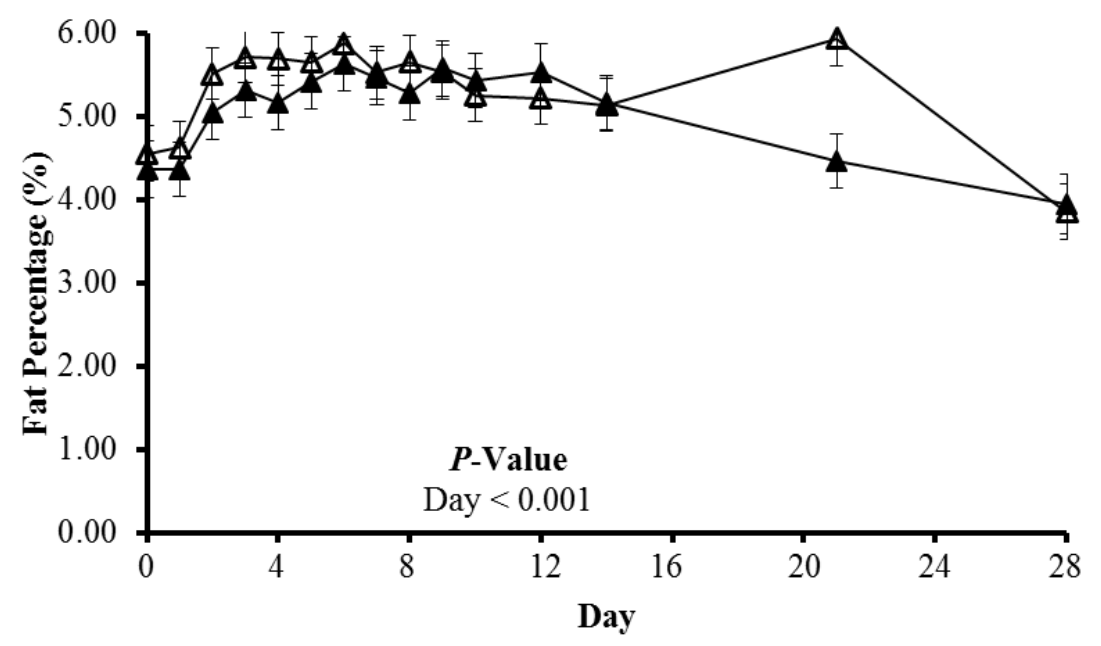

B

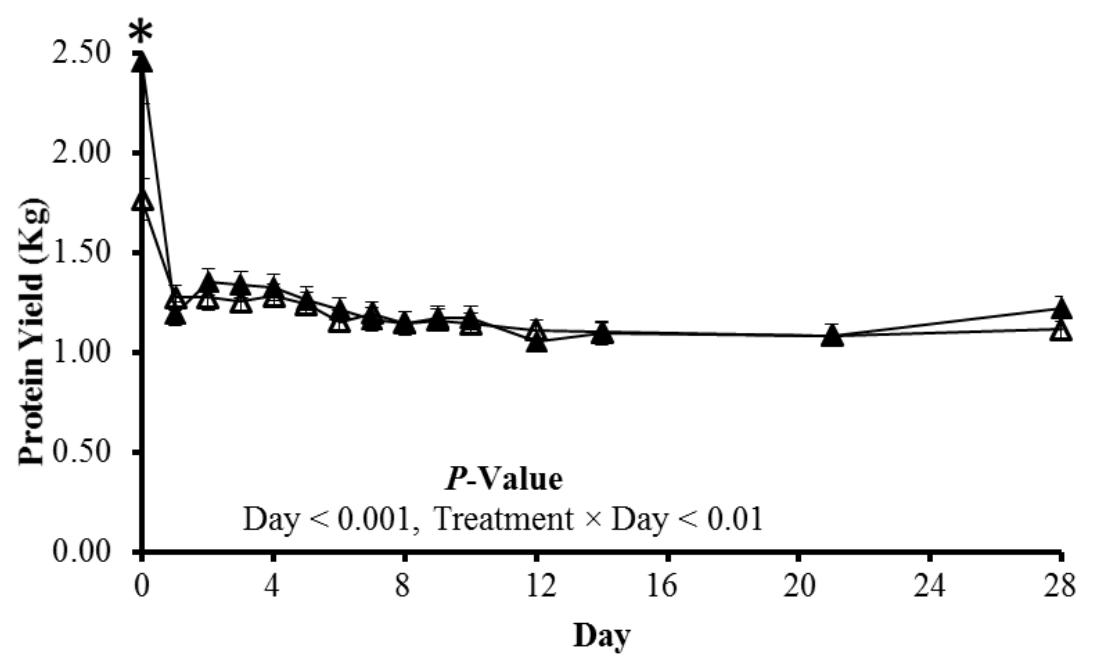

D

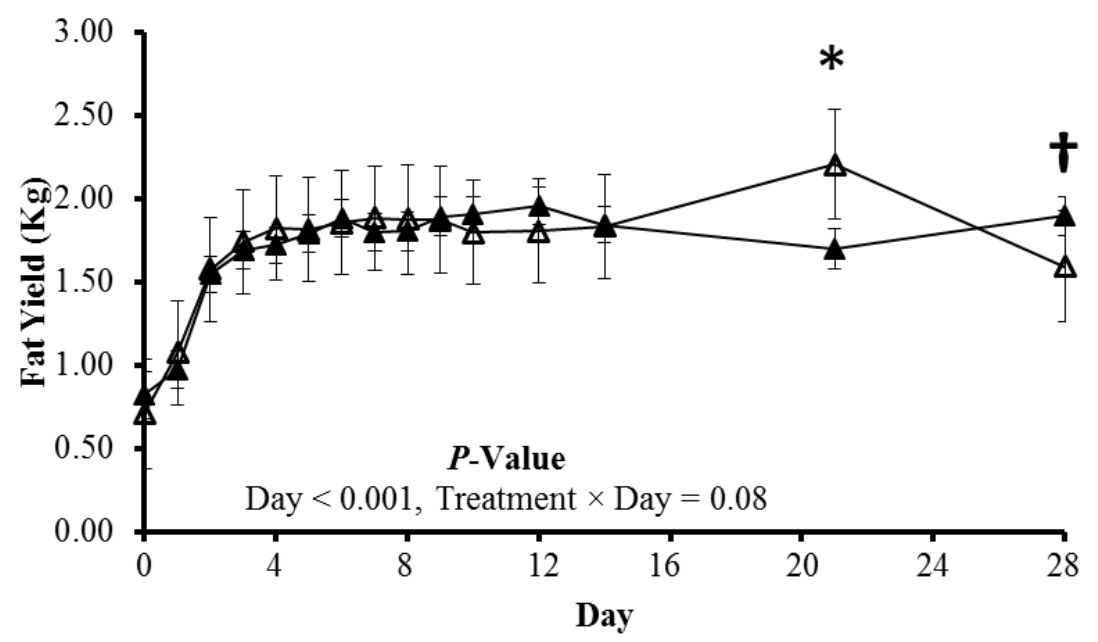


$\triangle$-Control $\triangle$ Mecovit

E

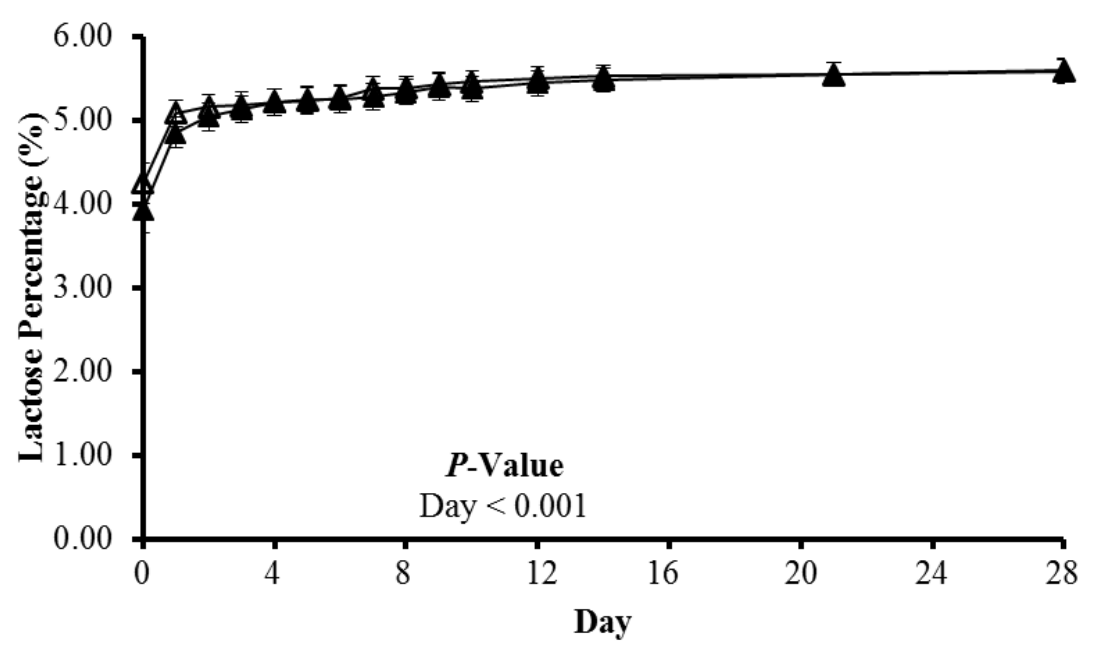

G

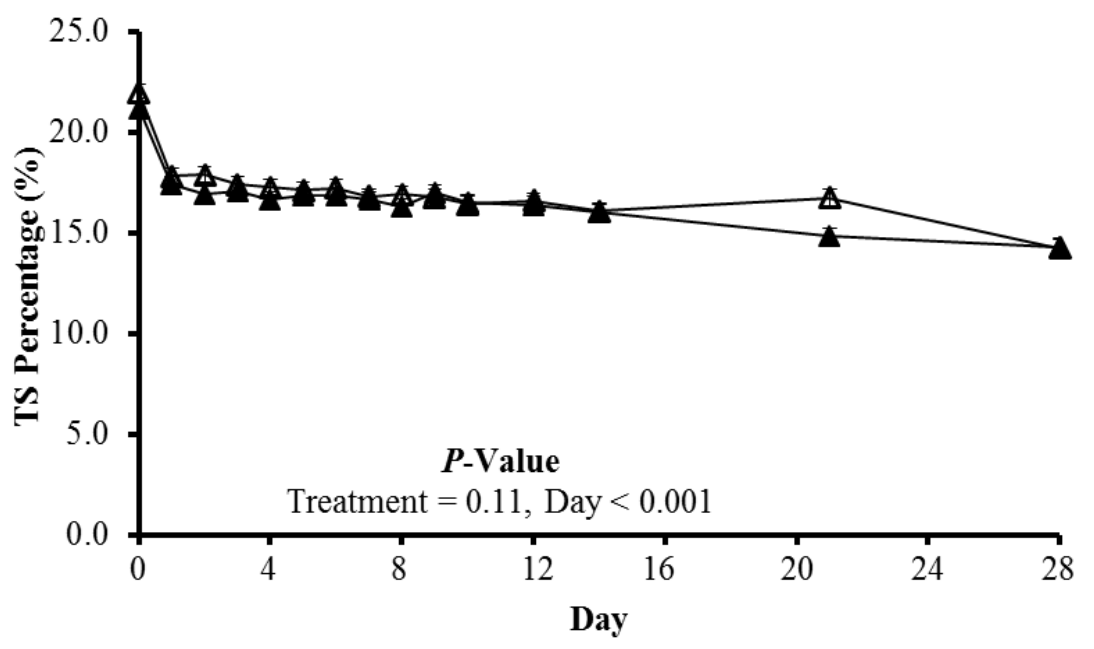

F

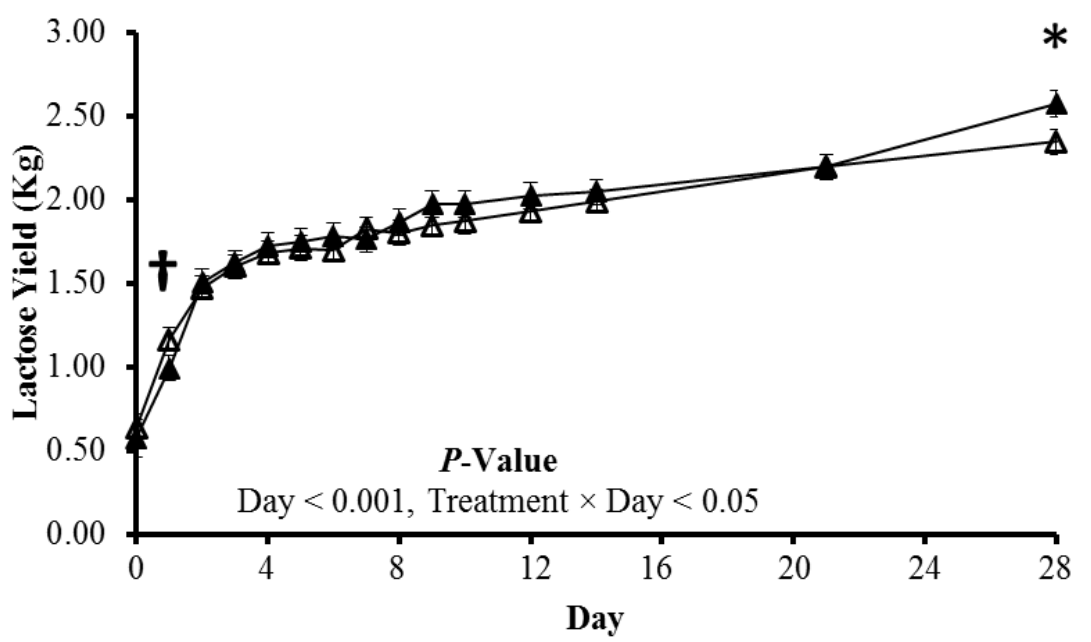

H

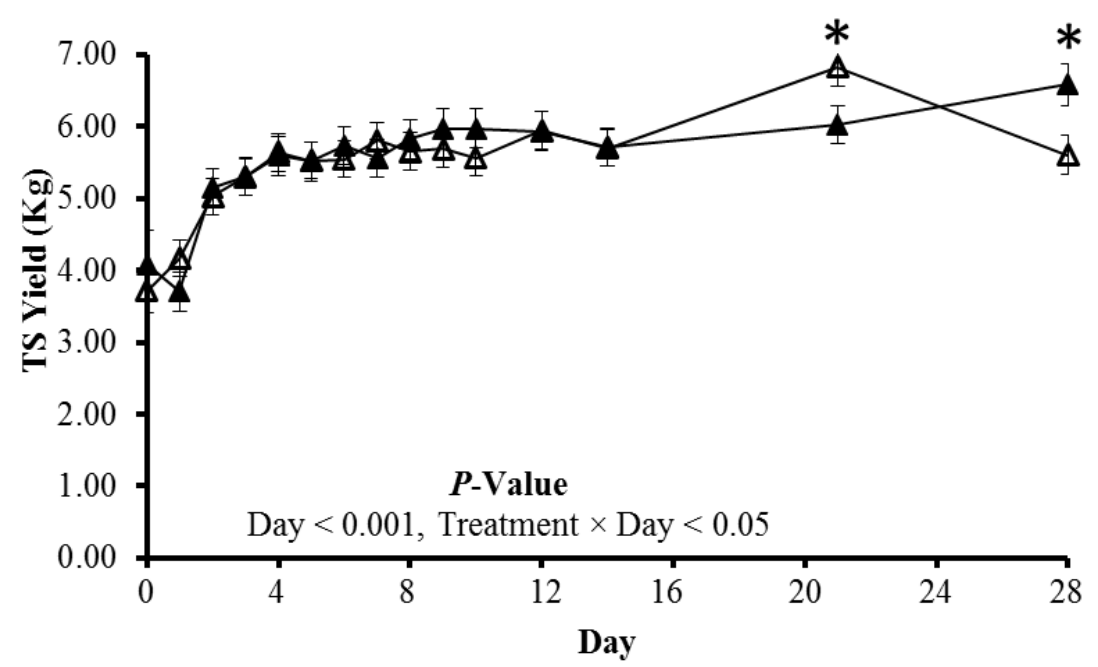


- Control

I

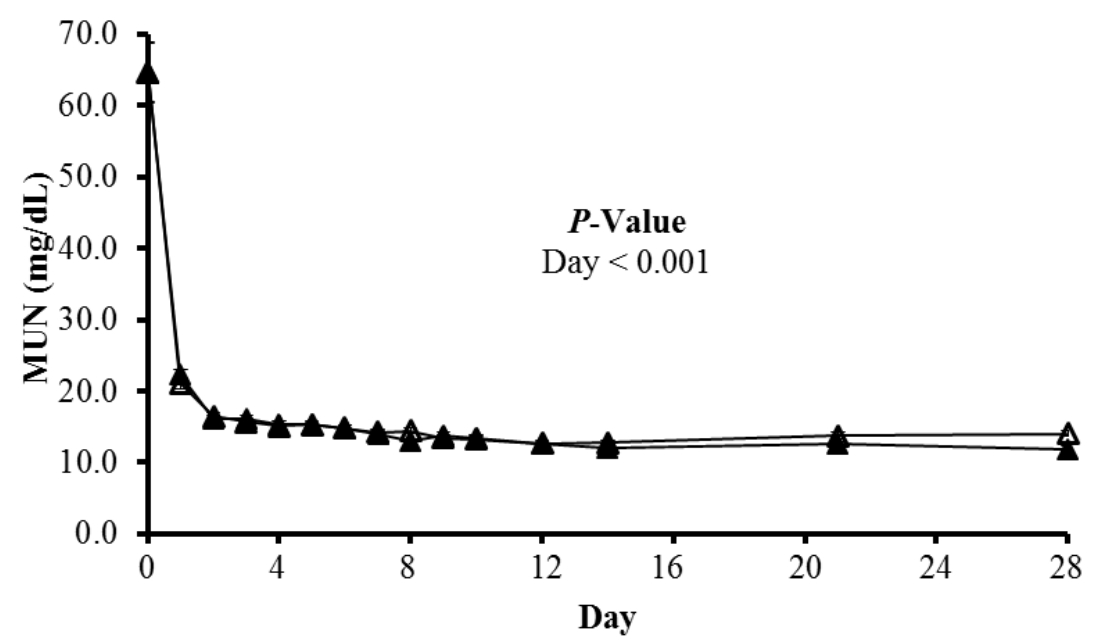

K

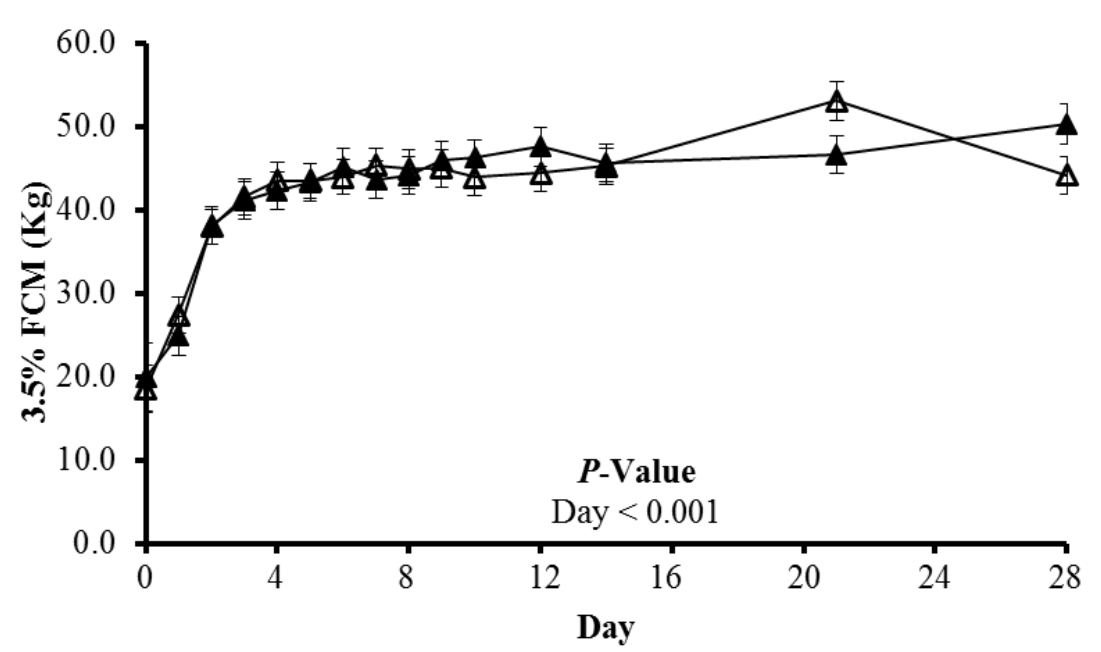

$\triangle$ Mecovit

J

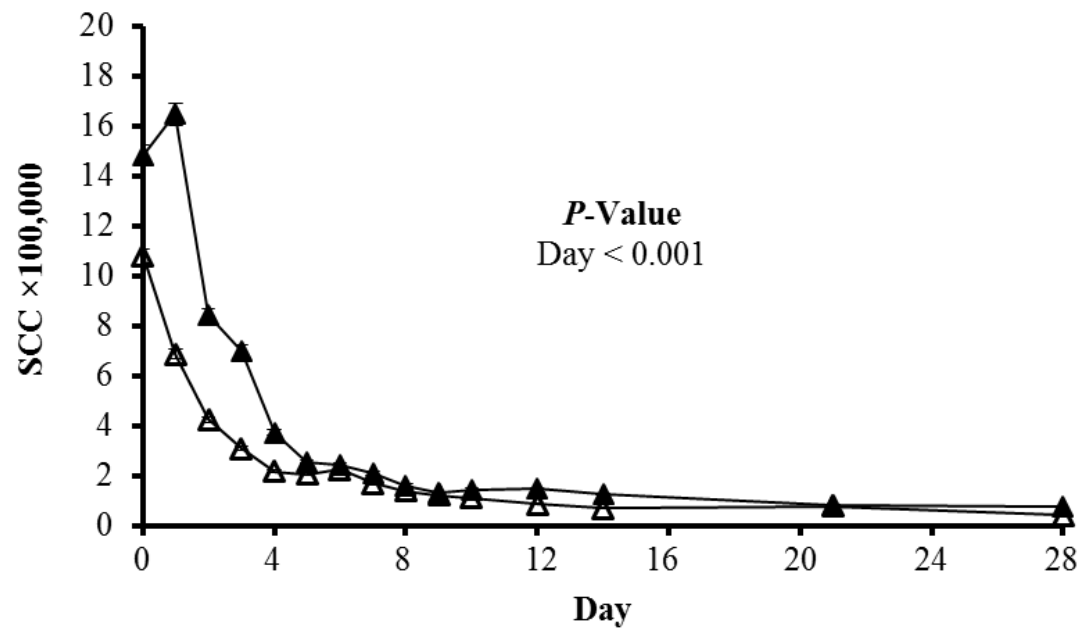

L

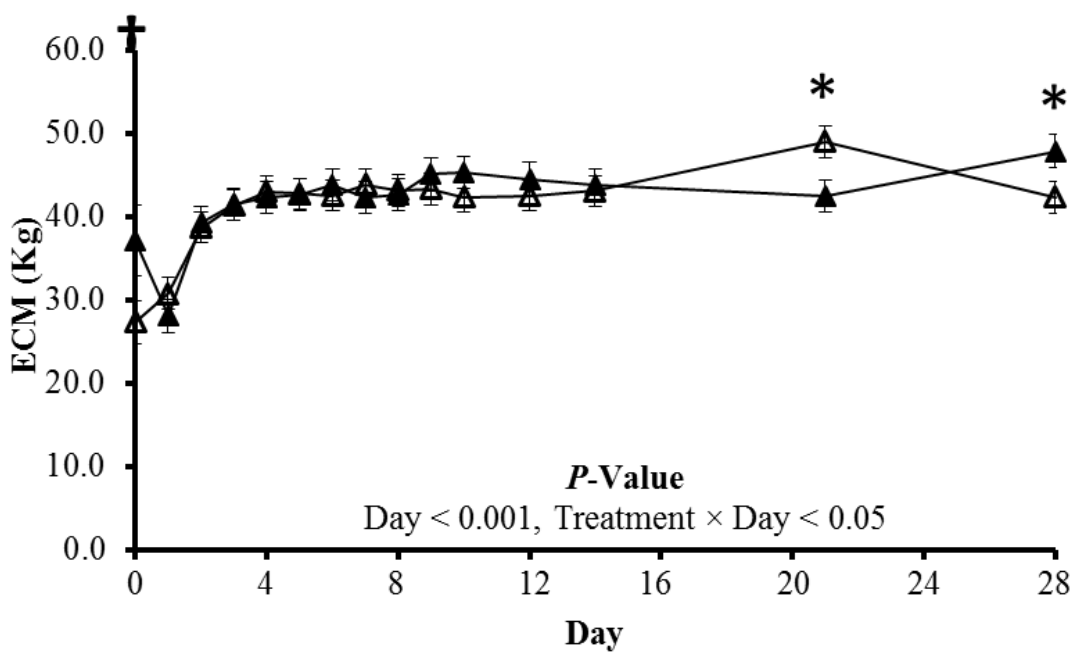


Figure 3-2: Milk composition responses to diets with or without micronutrient supplementation in the first month of lactation.

Changes in (A) milk protein percentage, (B) milk protein yield, (C) milk fat percentage, (D) milk fat yield, (E) milk lactose percentage, (F) milk lactose yield, (G) milk TS percentage, (H) milk TS yield, (I) MUN (J) SCC, (K) FCM (L) ECM.

$\mathrm{FCM}(\mathrm{Kg})=(0.4324 \times$ milk yield $)+(16.216 \times$ milk fat yield $)$.

$\operatorname{ECM}(\mathrm{Kg})=(12.82 \times$ milk fat yield $)+(7.13 \times$ milk protein yield $)+(0.323 \times$ milk yield $)$.

Data are least squares means and their standard errors; $* P<0.05, \uparrow P<0.10$. 


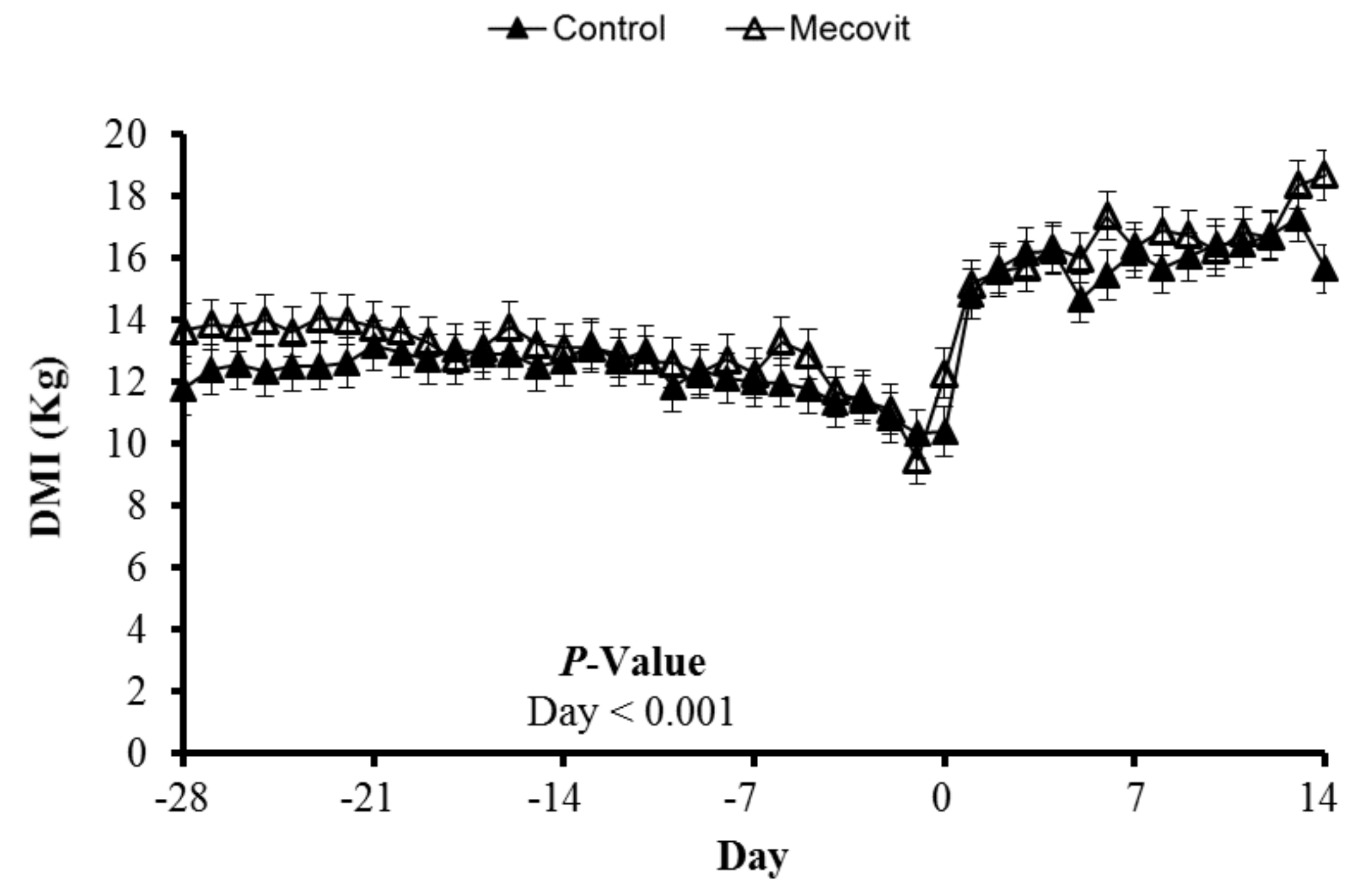

Figure 3-3: Dry matter intake responses to diets with or without micronutrient supplementation across the experiment. Data are least squares means and their standard errors. 
$\triangle$ Control $\triangle$ Mecovit

A

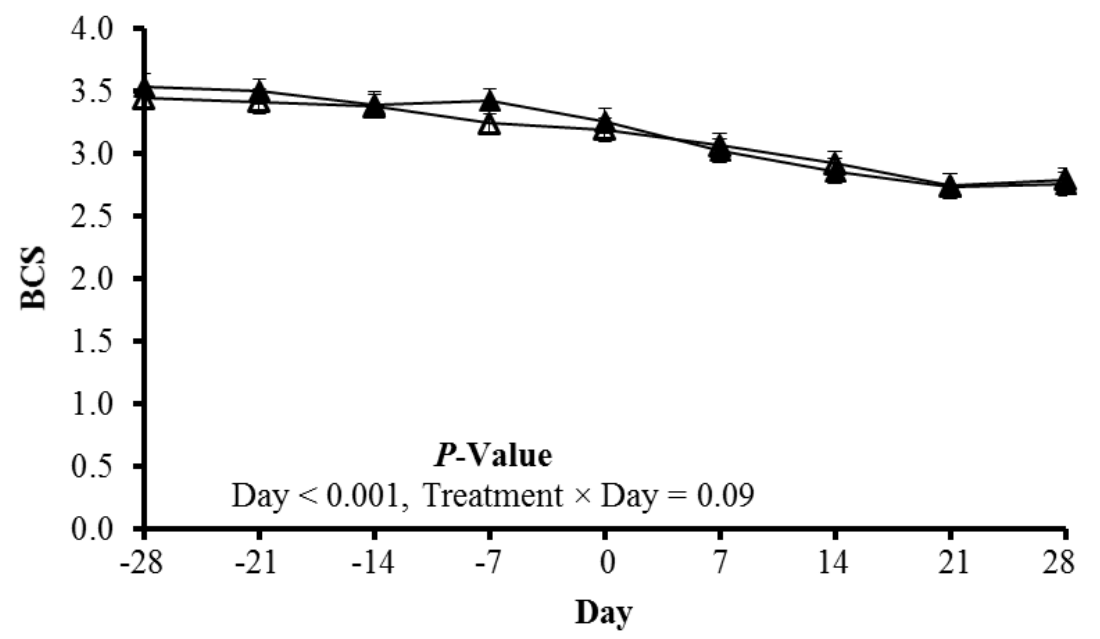

B

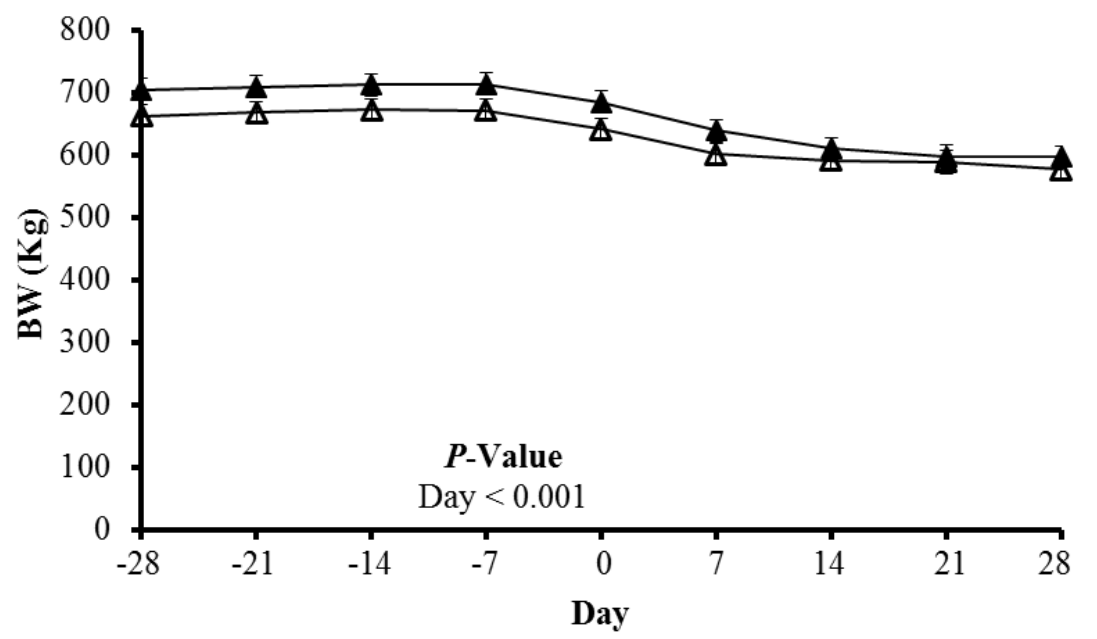

Figure 3-4: Body condition score and body weight patterns of dairy cows in the transition period. Changes in (A) BCS, (B) BW.

Data are least squares means and their standard errors. 
$\triangle$-Control $\triangle-$ Mecovit

A

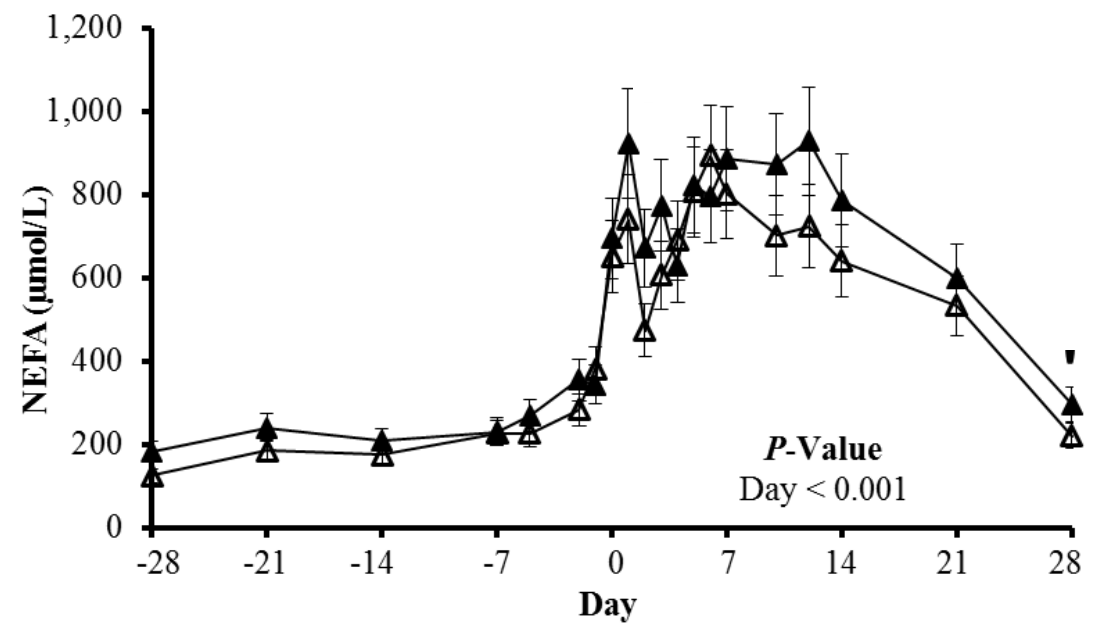

C

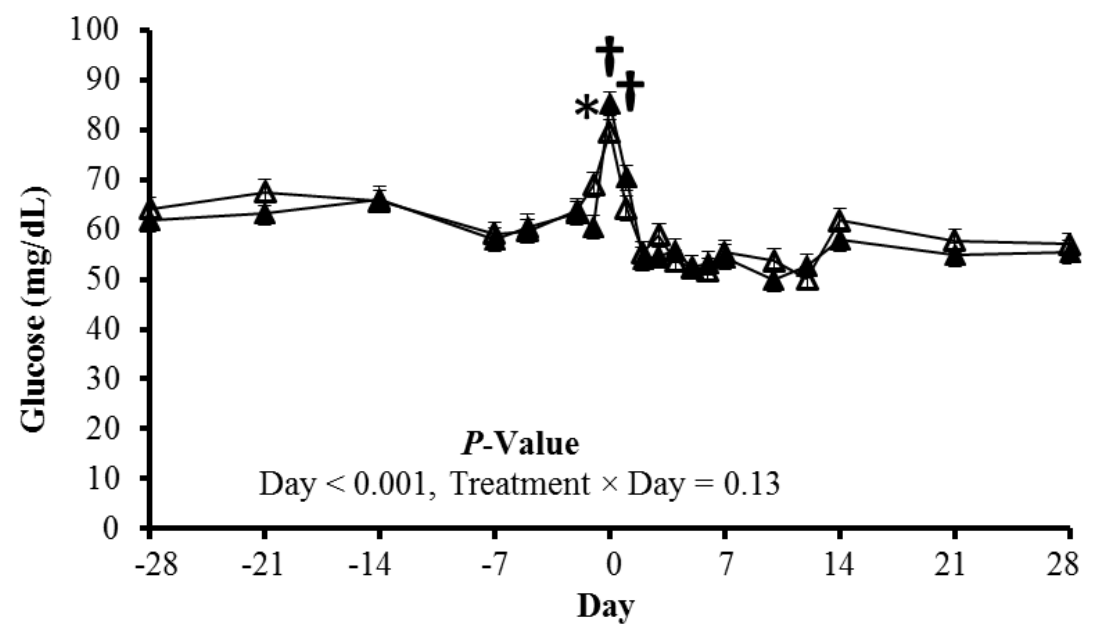

B

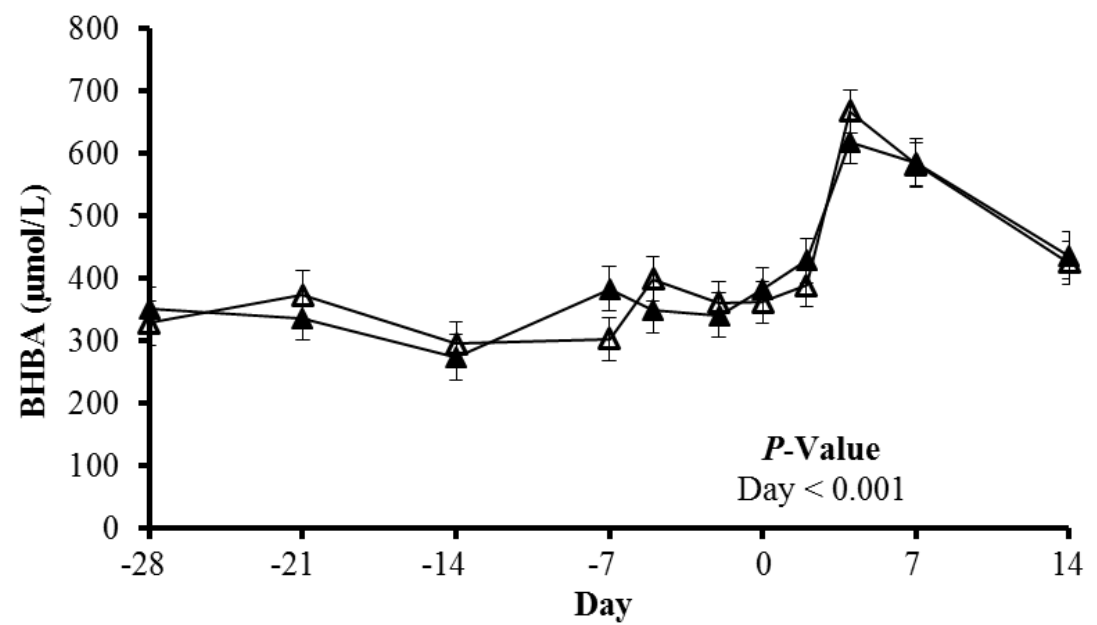

D

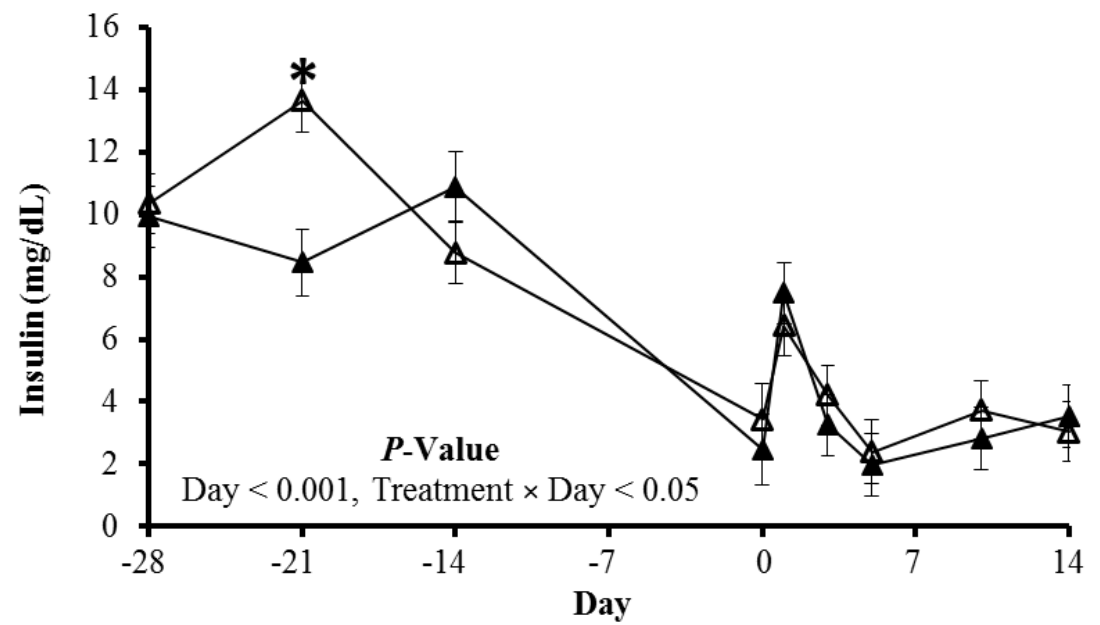


Figure 3-5: Plasma metabolites responses in periparturient dairy cows to diets with or without micronutrient supplementation. Changes in (A) NEFA, (B) BHBA, (C) glucose, (D) insulin.

Data are least squares means and their standard errors; $* P<0.05, \uparrow P<0.10$. 
$\triangle$-Control $\triangle-$ Mecovit

A

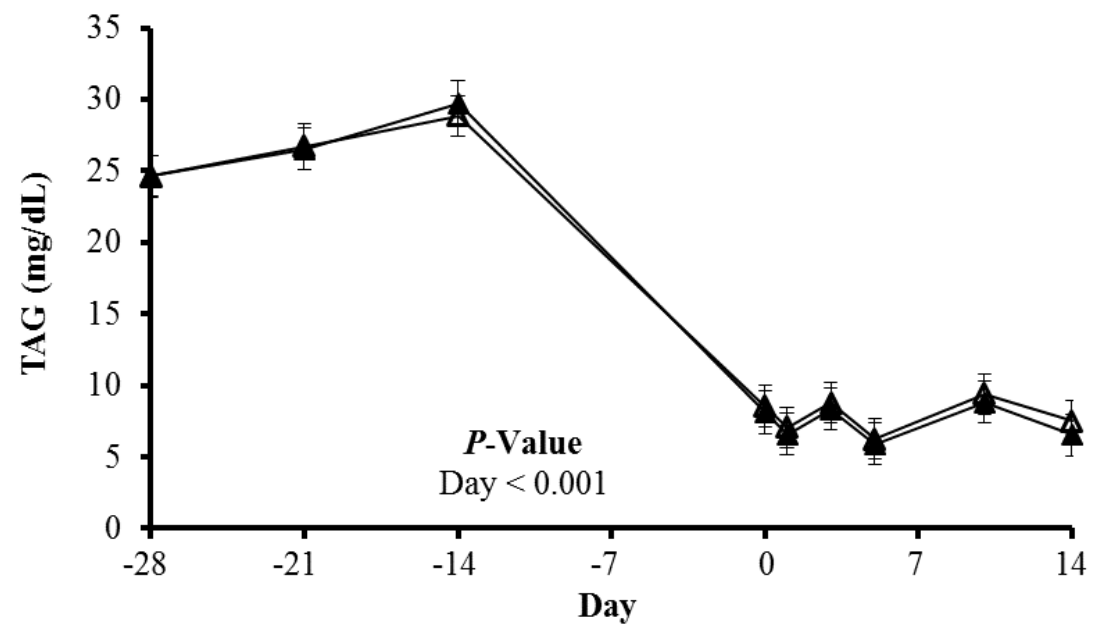

C

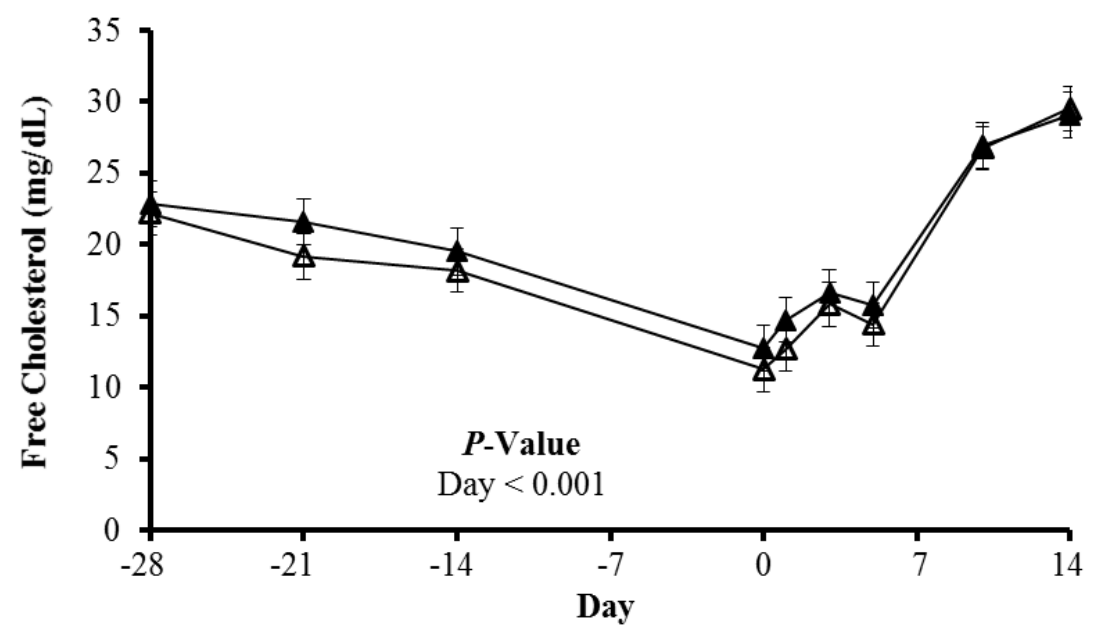

B

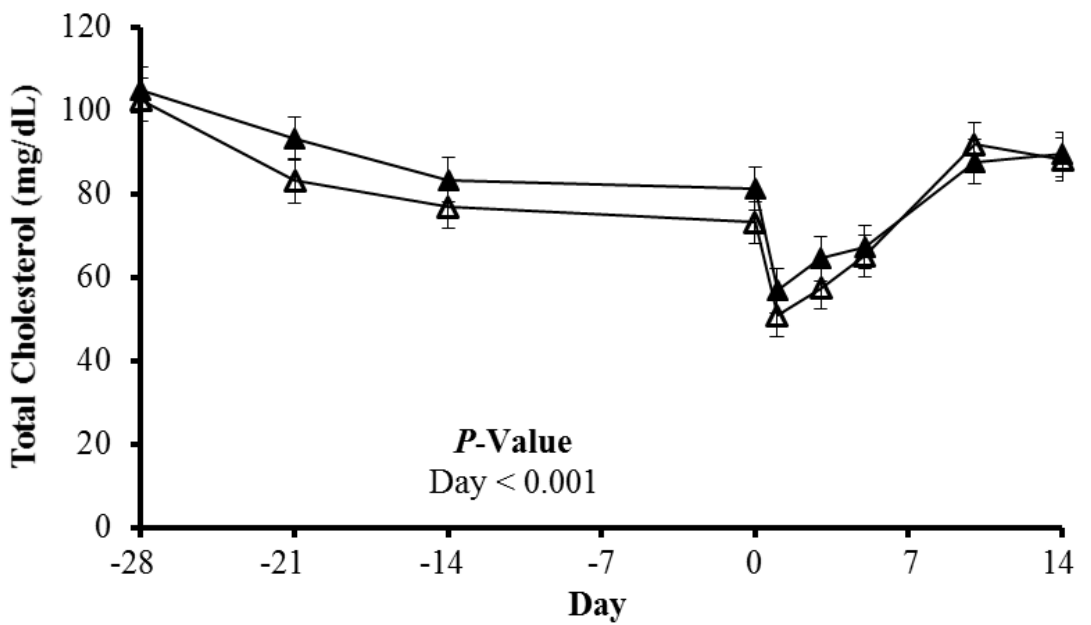

D

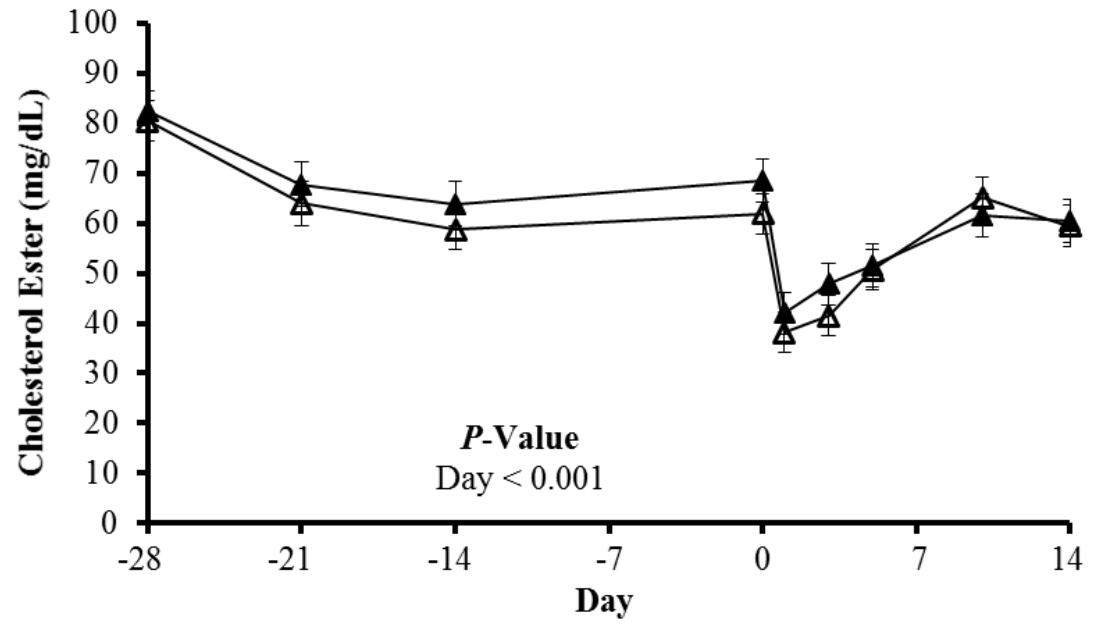


$\leftarrow$ Control

$\mathrm{E}$

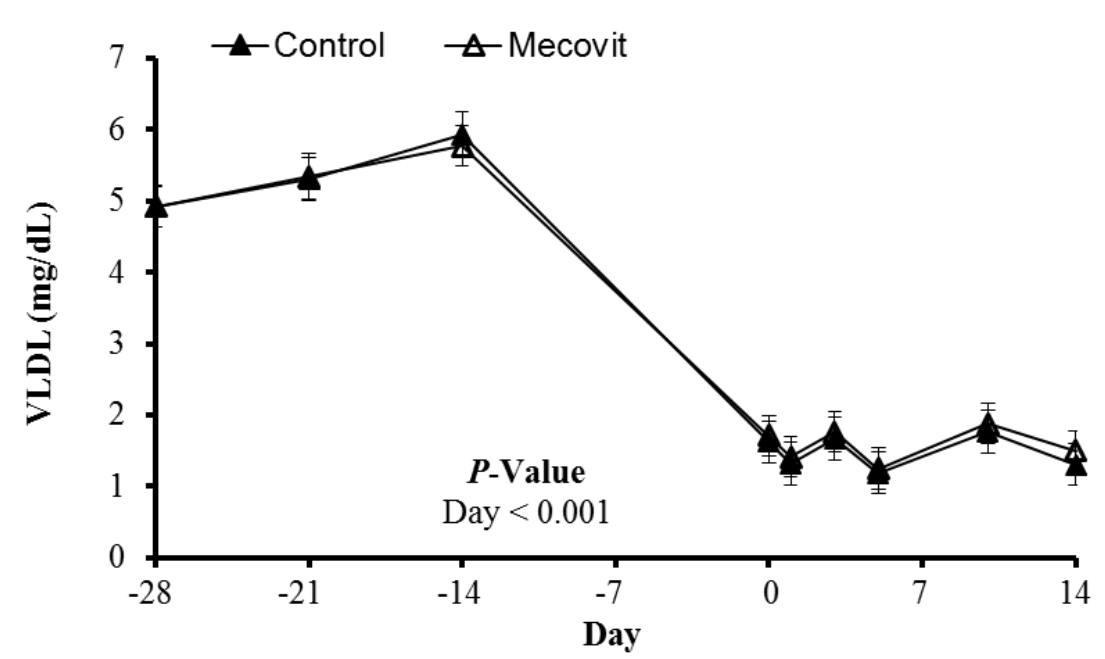

$\triangle$ Mecovit

$\mathbf{F}$

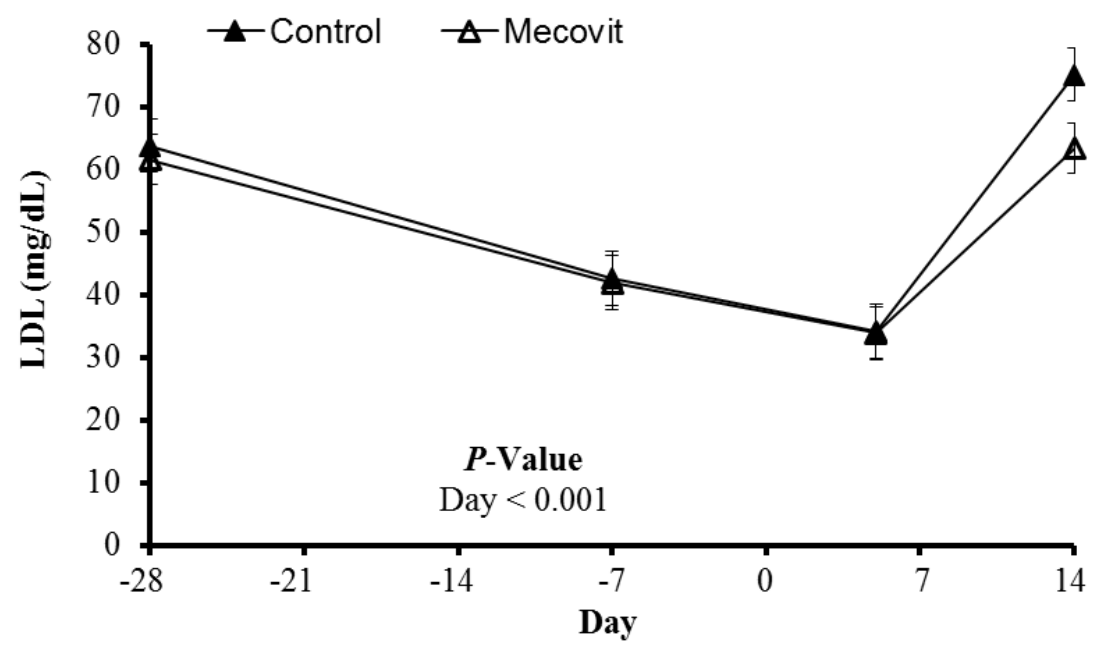

Figure 3-6: Plasma metabolites responses in periparturient dairy cows to diets with or without micronutrient supplementation Changes in (A) TAG, (B) total cholesterol, (C) free cholesterol, (D) cholesterol ester, (E) VLDL, (F) LDL-C.

Data are least squares means and their standard errors; unit: $\mathrm{mg} / \mathrm{dL}$. 
- Control $\square$ Mecovit

A

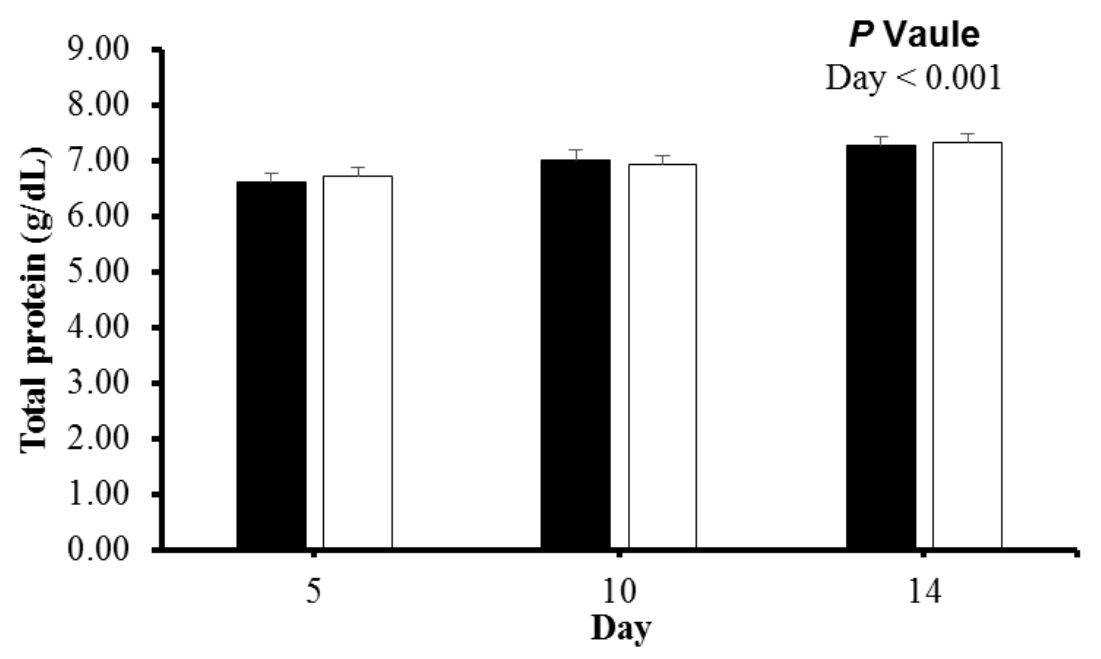

C

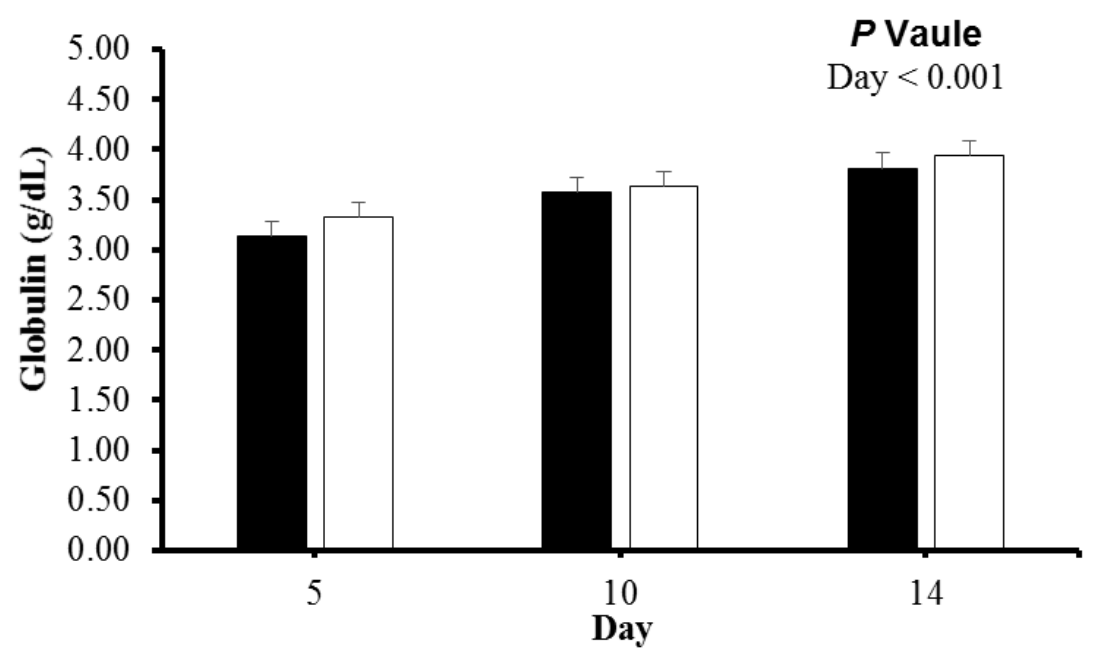

B

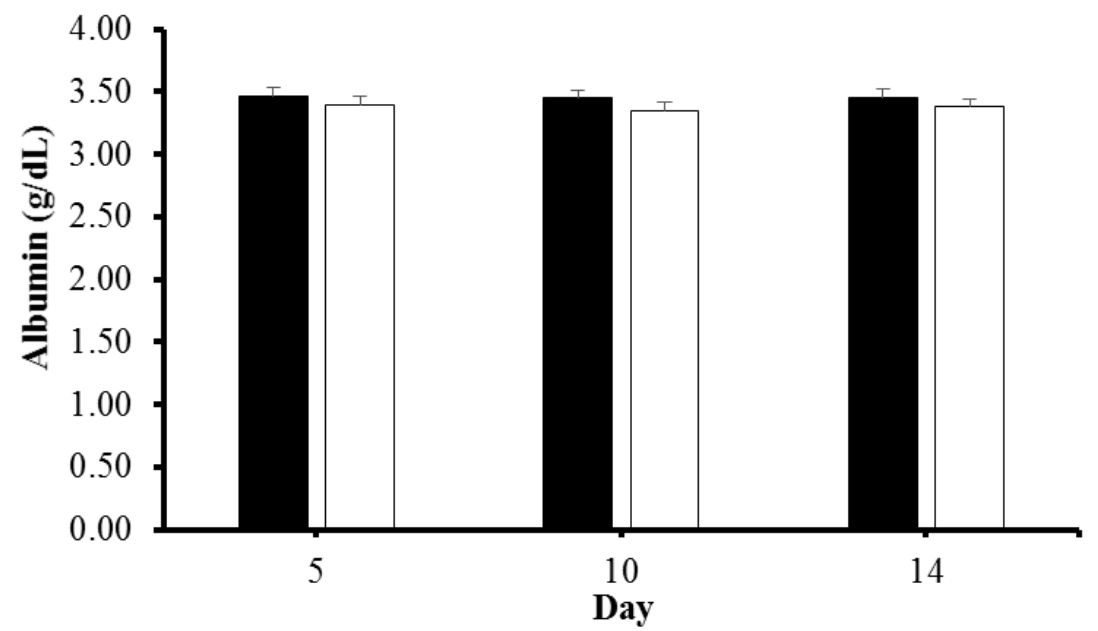

D

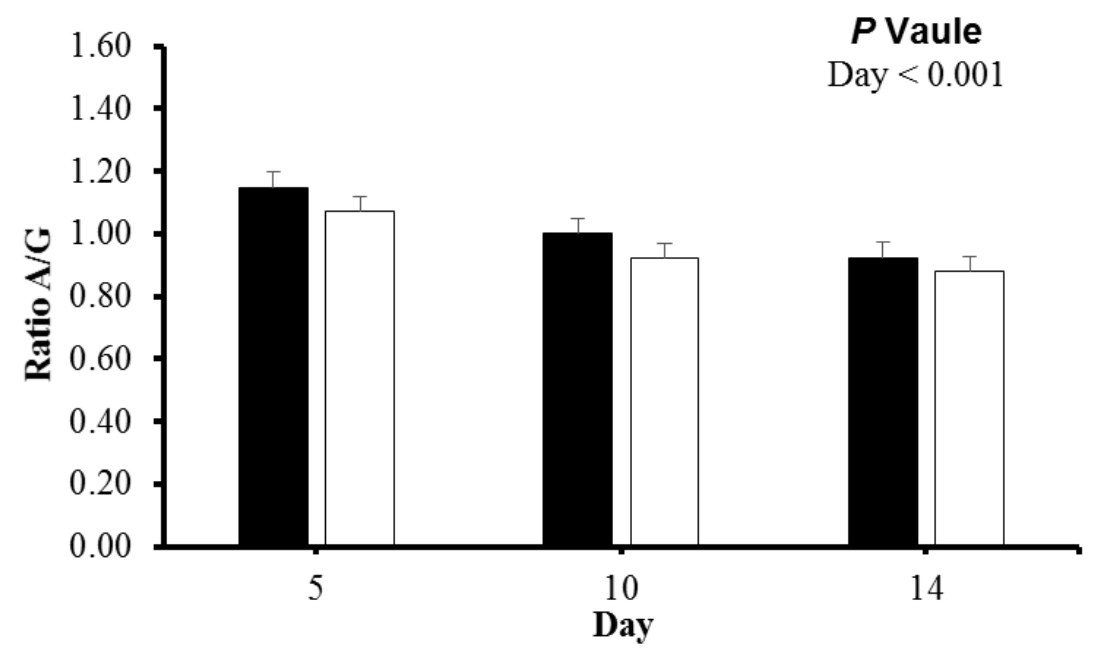


- Control $\square$ Mecovit

$\mathbf{F}$

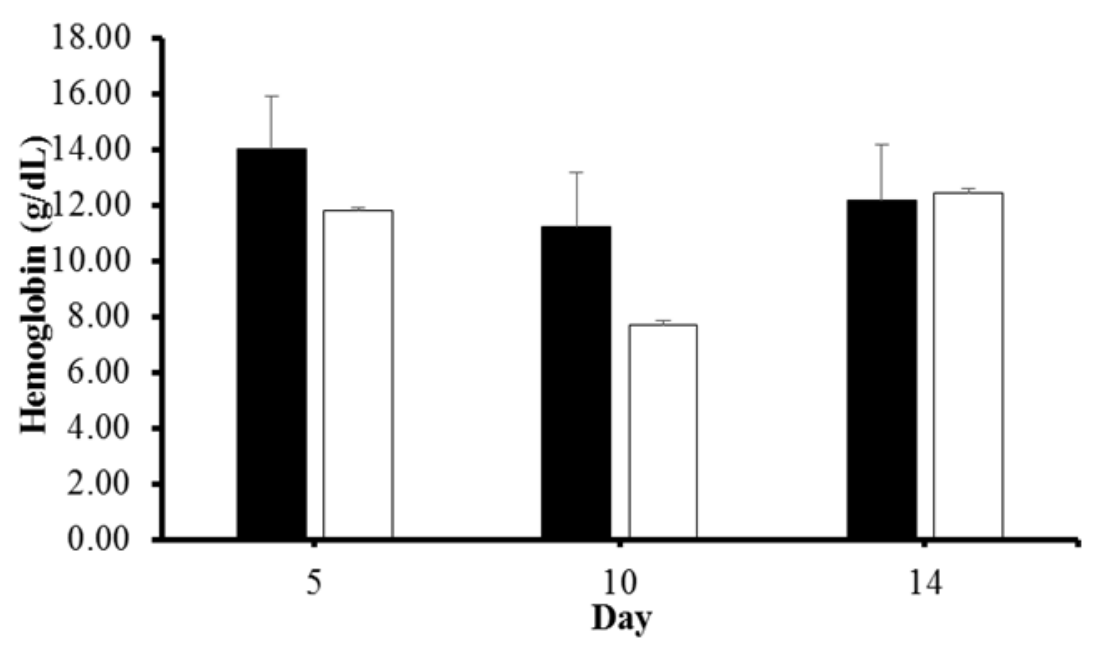

Figure 3-7: Serum protein metabolites responses in dairy cows to diets with or without micronutrient supplementation postpartum. Changes in (A) total protein, (B) albumin, (C) globulin, (D) ratio of albumin to globulin, (E) hemoglobin.

Data are least squares means and their standard errors; unit: $\mathrm{g} / \mathrm{dL}$. 
- Control $\square$ Mecovit

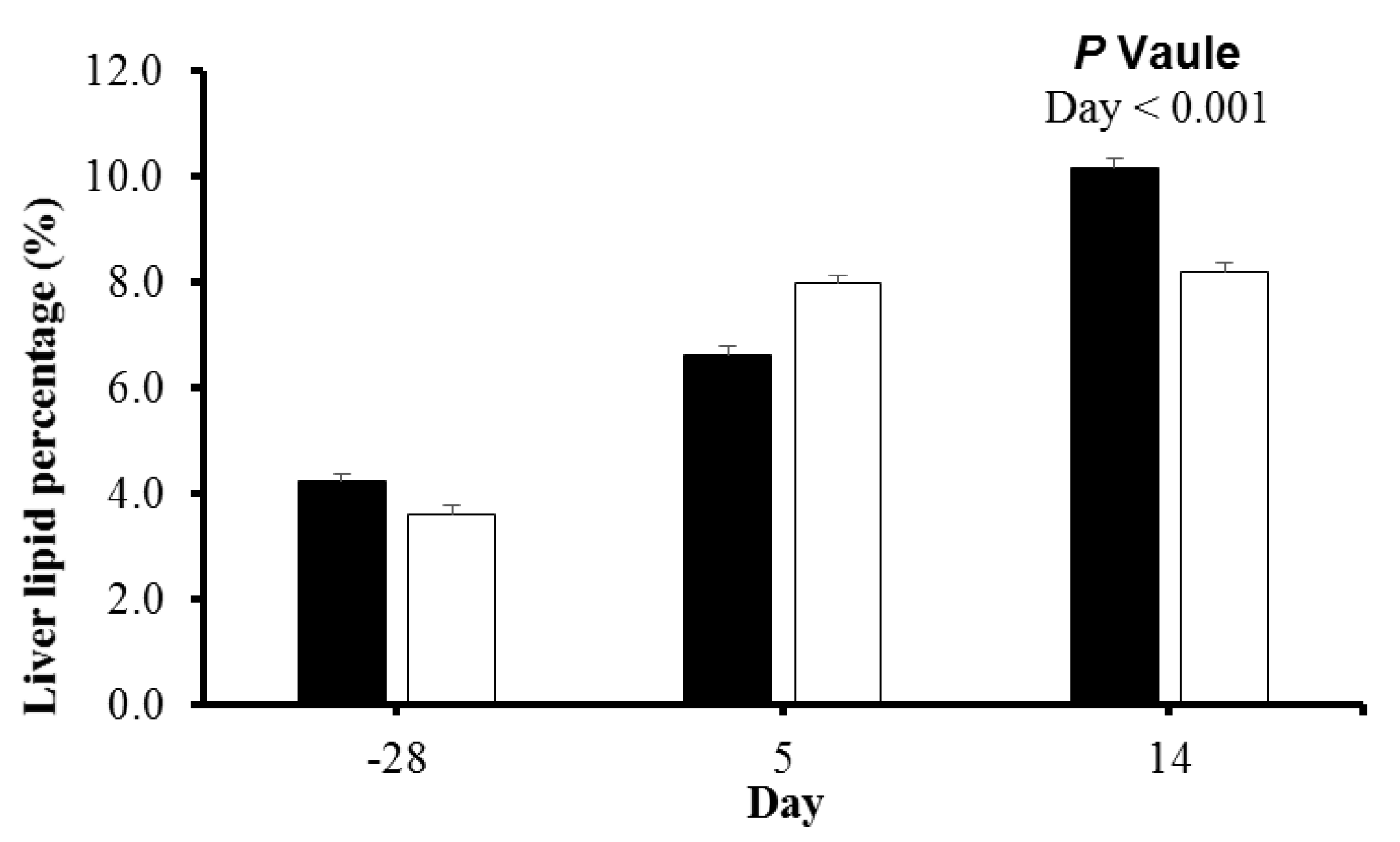

Figure 3-8: Liver lipid percentages in periparturient dairy cows to diets with or without micronutrient supplementation. Data are least squares means and their standard errors; unit: \% of wet liver weight. 


\title{
Chapter 4
}

\section{COMPARATIVE EFFECTS OF MULTIPLE SOURCES OF RUMEN-PROTECTED METHIONINE ON MILK PRODUCTION AND SERUM AA LEVELS IN MID- LACTATION DAIRY COWS}

\begin{abstract}
Methionine (Met) and lysine (Lys) are limiting amino acids (AA) in dairy cow diets. Supplementation of rumen-protected (RP) Met and Lys can improve milk yield, as well as yield and content of milk protein. Currently, multiple sources of RP-Met are available for supplementation; however, the comparative efficacy of these supplements to improve performance requires evaluation. Therefore, our objective was to characterize the production response of three RP-Met supplements in mid-lactation cows. Twelve multiparous Holstein cows (602 $\pm 46 \mathrm{~kg}$ body weight (BW), $174 \pm 18$ day in milk (DIM)) were used in a replicated $4 \times 4$ Latin square design with 21-d treatment periods. Dietary treatments included a corn silage and alfalfa haylage based diet (control; no added Met) supplemented with one of three RP-Met sources (Novimet (Innovad), Smartamine M (Adisseo), and Mepron M85 (Evonik)). Treatments were designed to maintain a Lys:Met ratio of 2.9:1. For control, Lys (RP-Lys; AjiPro) was added at $0.025 \%$ ration dry matter (DM). For RP-Met supplementation, Met (RP-Met) was added at 0.03\% ration DM. Cows fed RP-Met were provided Lys (RP-Lys) at $0.20 \%$ ration DM. Milk yields were recorded, and samples were collected during each period (d 19 to 21). Blood samples were collected on d 21 at 2, 4, and $6 \mathrm{~h}$ following feeding. Serum was then pooled. Following solid-phase extraction, 21 serum AA were quantified using gas chromatography tandem mass spectrometry. Data were analyzed using a mixed model with repeated measures (fixed effects of treatment and period). Treatments had no effect on dry matter intake (DMI) or milk yield. Treatment did not modify milk fat, protein, or lactose yield; however, milk protein content was
\end{abstract}


elevated with Smartamine M, relative to control or Novimet (3.30\% vs. 3.24\%, and 3.24\% respectively; $P<0.05)$. Milk fat and lactose concentration were not modified with treatments. Treatments tended $(P=0.12)$ to affect milk urea nitrogen (MUN), which Smartamine M being higher than control $(P=0.16)$. Smartamine $M$ increased serum Met concentration $(27.3 \mu \mathrm{M})$ as compared with control $(21.2 \mu \mathrm{M})$, Novimet $(22.7 \mu \mathrm{M})$, or Mepron M85 $(23.3 \mu \mathrm{M})(P<0.001)$. In a similar manner, Smartamine M lowered the serum Lys:Met ratio (4.5:1) as compared with control (5.2:1), Novimet (5.2:1), or Mepron M85 (5.1:1) $(P<0.05)$. Interestingly, Smartamine M was also able to enhance circulating glutamine, relative to control $(320.8$ vs. $289.5 \mu \mathrm{M} ; P=0.15)$. Treatment did not modify the serum levels of all other AA, including Lys. We conclude that Smartamine $\mathrm{M}$ increased circulating Met and milk protein content more effectively than Novimet or Mepron M85.

Key words: dairy cow, methionine, lysine 


\section{Introduction}

Dietary protein including rumen-degradable protein (RDP) and rumen-undegradable protein (RUP), together with endogenous protein, contribute to metabolizable protein (MP) requirements for maintenance, growth, pregnancy, and lactation in dairy cows. Rumendegradable protein needs to be digested by microorganisms in the rumen to synthesize microbial protein before reaching the small intestine for absorption. According to Schingoethe (1991), the AA profile of RUP in common feed ingredients is not balanced compared to that of the microbial protein, which is much more similar to the AA composition of milk. This can result in inadequate AA supply that limits the performance of dairy cows. The deficiencies in specific AA might be overcome through either feeding extra RUP containing more of these AA or feeding more RDP for more microbial protein. However, the former method brings excess AA into the diet and increases the expenditure of metabolizable energy in the excretion of urea (Watanabe, et al., 2006). For the latter method, supplying more RDP does not necessarily mean more microbial protein produced by the rumen microbes. Microorganisms in the rumen have limited capability to produce microbial protein with peptides, AA, and ammonia that comes from the digestion of RDP.

To solve this dilemma, supplementation of RP individual AA has been developed and applied by dairy producers for decades. RPAA are designed to escape from ruminal degradation easily and to be absorbed efficiently in the small intestine. Individual AA such as Met, Lys and histidine (His) are widely supplemented to diets in RP form in the industry. The technique of postruminal infusion is an alternative way to supply AA for the performance evaluation in the research area. Lara et al. (2006) demonstrated that rumen protected AA have been used to increase the balance of absorbed AA in duodenal flow to improve milk production. NRC (2001) 
showed that Met and Lys are the most two limiting AA for synthesis of milk and milk protein and also suggested that the required amounts of Met and Lys in MP for maximizing milk protein production are $2.4 \%$ and $7.2 \%$ respectively. Previous research proved that improved Met and Lys nutrition can variably increase DMI, milk production, yields and concentrations of protein and fat in milk (Donkin et al., 1989; Kazumasa et al., 2006; Socha et al., 2008). According to Piepenbrink et al. (1996), supplementing RP-Met and Lys might allow the feeding of diets with low crude protein $(\mathrm{CP})$ content to get similar milk and protein yields compared to high $\mathrm{CP}$ diets. Reducing CP in the diet could decrease both feed cost and urea excretion in the environment.

In contrast to the research mentioned above, some previous research did not report any significant increases in milk production performance after the addition of RP-Met and Lys. Lee et al. (2012) observed that treatment with RP-Met and Lys had no effect on milk yield, yields and concentrations of milk protein and fat compared to the diet without RP-Met and Lys. Similarly, Socha et al. (2008) reported no improvement in milk production with the supplementation of Met and Lys. A possible explanation for these negative results could be that these products were over-digested and released certain amount of Met in the rumen, or Met within the products was overprotected in the small intestine.

Among the technologies used in the industry, encapsulation of AA with polymeric compounds has proved to deliver AA postruminally effectively (Rogers et al., 1987). Watanabe et al. (2006) used RP-Met and Lys prepared by coating DL-Met with hydrogenated fat and L-Lys with hydro chloride, and observed increased yield and concentration of milk protein and increased concentration of milk fat, when adding the products to dairy diets. With the commercially available RP-Met sources, both Smartamine and Mepron products have been found to have a high level of protection in the rumen and bioavailability in the postruminal 
gastrointestinal gut (Patton, 2010). However, no research has been done with Novimet RP-Met, which is a new product from Innovad Corporation.

Our objective for this experiment was to compare the performance of Novimet RP-Met with the known Smartamine M and Mepron M85 under the addition of RP-Lys on milk production and serum AA concentrations.

\section{Materials and methods}

\section{Experimental design and animal management}

Experimental procedures were approved by the Institutional Animal Care and Use Committee at West Virginia University (WVU) (Morgantown). Twelve multiparous Holstein dairy cows were enrolled in a study completed at the WVU Animal Science Farm. Cows were housed in a free-stall barn and trained to access feed from Calan gate feeders (American Calan, Inc., Norwood, NH). Diets were mixed once a day and fed twice a day at 0900 and $1800 \mathrm{~h}$. Access to feed was blocked from 0700 to $0900 \mathrm{~h}$ to allow for orts and feed offered to be weighed. Cows were fed at $110 \%$ of expected intake, adjusted weekly, and provided free access to water. Cows were milked twice daily at 0800 and $1800 \mathrm{~h}$.

All cows were selected for this study based on DIM and milk yield. At the initiation of the experiment, the mean \pm SD of DIM, milk yield and BW for the cows were $174 \pm 18$ DIM, $31.0 \pm 4.5 \mathrm{~kg} / \mathrm{d}$, and $602 \pm 46 \mathrm{~kg}$, respectively. Cows were randomly assigned to 1 of 4 dietary treatments in a replicated $4 \times 4$ Latin square with 21 -d treatment periods. Treatments included control (0.025\% ration DM Lys), Novimet, Smartamine M, and Mepron M85 (0.03\% DM Met from three different sources plus $0.20 \%$ DM Lys, respectively). Each period consisted of a 2week diet adaptation phase and 1-week data collection phase. The diet provided was composed 
of $37 \%$ corn silage, $21 \%$ alfalfa haylage and $42 \%$ concentrate mix, and was formulated to meet nutrient recommendations for energy, protein, minerals and vitamins for dairy cows with corresponding BW (633 kg), DIM (170), milk production $(36 \mathrm{~kg} / \mathrm{d})$ and composition $(3.70 \%$ milk fat, and $2.95 \%$ milk protein) (Table 1; NRC, 2001). Alfalfa hay was chopped by a mixer for 2 hrs before mixing the total mixed ration (TMR) in order to reduce the particle size. Grain concentrates were weighed separately and mixed together in the feed mill. Feed ingredients including corn silage, alfalfa hay and grain mix and dairy pellets were weighed and mixed in a Triolet 1-700 TMR mixer. RPAA were weighed for each treatment and each cow daily and mixed into individual cow's TMR by hand completely before feeding.

\section{Sample collection and analysis}

Samples of ingredients and TMR were collected on a weekly basis and dried at $60^{\circ} \mathrm{C}$ for $48 \mathrm{~h}$ in a forced-air oven for storage and measurement of DM contents. Based on the weekly DM contents of ingredients, TMR was adjusted. At the end of the experiment, each dried feed ingredient sample was ground to pass a 1-mm screen of a Wiley mill (Arthur H. Thomas Co., Philadelphia, PA) and submitted them to a commercial laboratory for nutrient composition analysis by wet chemistry (Rumen Fermentation Profiling Lab, Morgantown, WV). Ether extraction of the feed was performed according to AOAC $(1995 ; 920.39)$. The ash content of feed samples was determined by combustion at $550^{\circ} \mathrm{C}$ overnight, and Organic matter (OM) content was calculated as 100 minus the percentage of ash (AOAC, 1995; 942.05).

Determination of the neutral detergent fiber (NDF) and acid detergent fiber (ADF) content in feed samples was done using the Ankom 200 Fiber Analyzer (Ankom Technology Corp., Macedon, NY). The total N content in feed was analyzed according to AOAC $(1995 ; 976.05)$ 
using an automated Tecator digestion system (Tecator, Inc., Herndon, VA). The concentration of sugars in feed was determined by the extraction procedure adapted from Deriaz (1961). Reducing sugars were determined with a spectrophotometer and potassium ferricyanide. Starch content of feed samples was determined by the procedure of Smith (1969).

Milk yield was recorded from the p.m. milking on $\mathrm{d} 15$ to the a.m. milking on $\mathrm{d} 1$ of next period and milk samples were collected from each cow from the p.m. milking on $\mathrm{d} 19$ to the a.m. milking on $\mathrm{d} 1$ of next period. Milk samples were sent to Dairy One (Hagerstown, MD) and were analyzed for content of fat, true protein, lactose, total solids (TS), MUN and somatic cell count (SCC) with midinfrared spectroscopy.

Blood samples were collected via coccygeal vein or artery at 1100, 1400 and 1700h on d 21 of each period. Serum tubes $(10 \mathrm{~mL})$ were used for the blood sample collection and were allowed to clot for $30 \mathrm{~min}$ in a heat box set at $37^{\circ} \mathrm{C}$. Serum samples were centrifuged for $10 \mathrm{~min}$ at $3,400 \times g$ and were aliquoted into RNA centrifuge tubes. Serum samples of each cow at three different time points were pooled together. Sample aliquoted were taken back to the lab in a dry ice box and were stored at $-80^{\circ} \mathrm{C}$ until analysis. The profile of serum AA was quantified by using gas chromatography tandem mass spectrometry (GC/MS/MS) in our lab. The Phenomenex EZ:faastTM AA analysis kit was used and the operational procedure by Badawy et al. (2008) followed.

\section{Statistical analyses}

Yields of 3.5\% fat-corrected milk (FCM), energy-corrected milk (ECM), and yields and percentages of milk components were calculated using milk yield and components for each milking, summed for daily total, and averaged for each collection period. 
Data for DMI, milk yield, milk composition and concentrations of AA in serum were analyzed with the MIXED model procedure of SAS (version 9.3; SAS Institute Inc., Cary, NC), according to the following model:

$$
\mathrm{Y}_{\mathrm{ijk}}=\mu+\mathrm{C}_{\mathrm{i}}+\mathrm{P}_{\mathrm{j}}+\mathrm{T}_{\mathrm{k}}+\left(\mathrm{P}_{\mathrm{j}} \times \mathrm{T}_{\mathrm{k}}\right)+\mathrm{e}_{\mathrm{ijk}}
$$

Where Yijk $=$ dependent variable, $\mu=$ overall mean, $\mathrm{Ci}=$ random effect of cow $(\mathrm{i}=1$ to 12), $\mathrm{Pj}=$ fixed effect of sampling period $(\mathrm{j}=1$ to 4$), \mathrm{Tk}=$ fixed effect of treatment $(\mathrm{k}=1$ to 4$)$, $\mathrm{Pj} \times \mathrm{Tk}=$ interaction between sampling period and treatment, and eijk $=$ residual error . Normality of the residuals was checked with normal probability and box plots and homogeneity of variances with plots of residual versus predicted values. When necessary, data was logarithmic transformed for the right-skewed data including SCC, His, and branched-chain AA (BCAA). Data values were considered as outliers and removed from analysis when studentized residuals were over $|3.0|$. Three common covariance structures including variance components, first-order autoregressive, compound symmetry for repeated measures (periods) analysis were evaluated and structure with the smallest Akaike's information criterion coefficient was selected for analysis. The DIFF option in SAS was used to test treatment differences among least square means. Significance was declared at $P<0.05$ and trends at $P<0.15$. All results are expressed as least squares means and their standard errors.

\section{Results and discussion}

\section{Dry matter intake}

Dairy cows DMI averaged $25.40 \mathrm{~kg} / \mathrm{d}$ and was not affected by treatments (Table 2). Results in this experiment were consistent with previous studies, which reported no differences in DMI for supplementation of RP-Lys and Met to mid-lactation dairy cows (Donkin et al., 1989; 
Pipenbrink et al., 1996; Socha et al., 2008; Lee et al., 2012 and 2015). Cows fed Smartamine M or Mepron M85 ate 0.71 or $0.61 \mathrm{~kg} / \mathrm{d}$ numerically more feed compared to control cows (Table 2). In Benefield et al. (2009), cows fed $12 \mathrm{~g} / \mathrm{d}$ Smartamine RP-Met tended to have increased DMI, when compared to cows fed Mepron or cows fed excess Lys supply of the control diet. In contrast to mid-lactation cows, DMI response in early lactation cows fed RPAA varied a lot in different studies. A study by Socha et al. (2008) showed that DMI tended to increase linearly with increasing amounts $(0,3,5,7,10.5,16 \mathrm{~g} / \mathrm{d})$ of Met duodenally infused when the diet met all nutrient requirements. Dry matter intake of cows without RPLys and Met were higher than those with RPAAs in a basal ration limiting in intestinally available Met and Lys (Watanabe et al., 2006; Kazumasa et al., 2006). The cause for this lower DMI of cows fed RP-AA is still unknown. However, the majority of early-lactation studies indicated that there was no difference in DMI after the addition of RP-Met and Lys (Pisulewski et al., 1996; Armentano et al., 1997; Socha et al., 2005). Compared with multiparous cows, primiparous cows seemed to have greater responsiveness in DMI to supplementation with Met and Lys, but the mechanism is unknown.

\section{Milk yield and components}

Similar to the pattern of DMI response, milk yield averaged $27.5 \mathrm{~kg} / \mathrm{d}$, and was not affected by treatments (Table 4-2). The lack of difference in DMI likely contributed to this result. No significant differences in milk yield was also observed when Donkin et al. (1989) added 15 g/d RP-Met and $40 \mathrm{~g} / \mathrm{d}$ RP-Lys to a basal diet with adequate CP. The amounts of RPAA supplemented by Donkin et al. (1989) were around 1.5 times of the Met, but around $15 \mathrm{~g} / \mathrm{d}$ less RP-Lys than the current experiment. The combination of Met and Lys added to adequate CP diet did not improve milk yield of mid-lactation cows. Also, Lee et al. (2015) showed that addition of 
100 g/d RP-Lys or 24 g/d RP-Met and 100 g/d RP-Lys to a CP-deficient diet did not affect the milk yield. Piepenbrink et al. (1996) found similar responses when topdressing $11 \mathrm{~g} / \mathrm{d}$ Met and 35 g/d Lys, 22 g/d Met and 70 g/d Lys, or 33 g/d Met and 106 g/d Lys (50\%, 100\%, or 150\% predicted deficiency of Met and Lys respectively) to a low CP (14\%) diet. Taken together, it indicates that supplementation of both RP-Met and Lys to adequate or inadequate CP diet would not cause an alteration in milk production in mid-lactation period. However, Socha et al. (2008) found that milk yield declined linearly when adding $0,5,10,15$ or $20 \mathrm{~g} / \mathrm{d}$ Met to the adequate MP diet supplemented with 8 g/d Lys. On the other hand, milk yield of cows fed $18 \% \mathrm{CP}$ diet was greater than cows feed 14\% CP diet without RPAA (Piepenbrink et al., 1996). A study by Broderick et al. (2008) also found similar results in milk yield when comparing cows fed 17.3\% $\mathrm{CP}$ diet and $16.1 \% \mathrm{CP}$ diet. The elevated milk production in these two studies above was probably because higher CP caused greater DMI, which presumably improved the availability of AA and energy.

Compared with the responses to RP-Met and Lys in mid-lactation cows, the effect of RPAA is also minimal on milk yield for early lactation cows. There was no impact of supplemental Met and Lys on milk yield in previous studies (Pisulewski et al., 1996; Armentano et al., 1997; Kazumasa et al., 2006; Watanable et al., 2006; Socha et al., 2008;). Amounts of Met and Lys in RP form or duodenal infusion were from 3 to $24 \mathrm{~g} / \mathrm{d}$ and from 10 to $16 \mathrm{~g} / \mathrm{d}$ respectively. Cows probably have higher priority to transport nutrients toward mammary gland in the early lactation period than other periods. On the other hand, Socha et al. (2008) found that milk yield produced by cows within 7 weeks of calving increased linearly with increasing amounts of infused methionine. 
Milk protein percentage of cows fed Smartamine $\mathrm{M}$ was significantly greater than control and Novimet cows (3.30\% vs. 3.24\% and 3.24\%; $P<0.05$ respectively) (Table 4-2). Protein percentage of cows fed Mepron M 85 (3.28\%) was numerically higher than control and Novimet, but numerically lower than cows fed Smartamine M (Table 4-2). Among these three RP-Met products, Smartamine M had higher efficacy at improving milk protein percentage than Mepron M85 and Novimet. Benefield et al. (2009) reported that cows fed $12 \mathrm{~g} / \mathrm{d}$ Smartamine M tended to have increased milk protein percentage, whereas cows fed $12 \mathrm{~g} / \mathrm{d}$ Mepron Met significantly increased milk protein percentage when compared with a control diet $(3.01 \%$ vs. $2.94 \%, P<0.13$; $3.03 \%$ vs. $2.94 \%, P<0.05)$. The average milk protein concentration of 18 studies for supplementation of Smartamine or Mepron Met product was 2.89\% and 2.92\% and there was no significant difference between them on improvement of milk protein percentage (Patton et al., 2010).

Our findings are supported by previous published research. Donkin et al. (1989) reported that milk protein percentage increased by $0.10 \%$ through the addition of Lys $(40 \mathrm{~g} / \mathrm{d})$ and Met $(15 \mathrm{~g} / \mathrm{d})$ (ratio was 2.70:1). Supplementation of Lys and Met (3.03:1, ratio) to a low CP diet elevated milk protein content to reach the level produced by cows with an adequate $\mathrm{CP}$ diet (Piepenbrink et al., 1996; Lee et al., 2012). Socha et al. (2008) observed that milk protein content increased linearly with increasing amounts of Met $(0,5,10,15,20 \mathrm{~g} / \mathrm{d})$ infused. In this study, the ratios of Lys: Met ranged from 1.59 to 0.4 , which was much lower than the ratios mentioned above. The implication was that Met was far more limiting in the basal diet in the experiment by Socha et al. (2008). These previous studies suggested that supplemental Met and Lys to midlactation cows could increase the amounts of essential AA (EAA) (particularly Met and Lys) and expand the pool of available AAs for the mammary gland. In early lactation period, 
supplementing diets with RP-Met and RP-Lys had similar effects on elevating milk protein percentage (Pisulewski et al., 1996; Armentano et al., 1997; Kazumasa et al., 2006; Watanabe et al., 2006). For these studies, the ratios of Lys to Met were from 2.5 to 0.42 , which were also lower than the ratio (3:1) recommended by the NRC, (2001). According to Socha et al. (2005), responses of RPAA on milk protein concentration were not consistent across dietary CP level. Addition of RP-Met and Lys to $18.5 \%$ CP elevated milk protein content by $0.21 \%$, whereas supplementation of RP-Met and -Lys to 16\% CP had no effect on milk protein content (Socha et al., 2005).

Milk protein yields averaged $0.87 \mathrm{~kg} / \mathrm{d}$ and were not affected by treatments which could be attributed to the similar milk yields and slightly different milk protein percentages across treatments. Responses on milk protein yield in this experiment were consistent with previous studies (Piepenbrink et al., 1996; Socha et al., 2008; Lee et al., 2012). However, Donkin et al. (1989) found that milk protein yield was increased by $4 \mathrm{~g} / \mathrm{d}$ through the addition of Met ( $1 \mathrm{~g} / \mathrm{d})$ and Lys (2.7 g/d). As we can see, mid-lactation cows have low sensitivity to Met and Lys on milk protein yield. The most common response to RPAA in early-lactation period is that cows have elevated milk protein yield compared with cows fed basal diets (Armentano et al., 1997; Socha et al., 2005; Kazumasa et al., 2006; Watanabe et al., 2006). Armentano et al. (1997) found that milk protein yield increased by $5.13 \mathrm{~g} / \mathrm{d}$ by adding $1 \mathrm{~g} / \mathrm{d}$ Met and $1.28 \mathrm{~g} / \mathrm{d}$ Lys. An earlier study even observed milk protein yield increased linearly with increasing supplemental Met to the diets. The authors reported that milk protein yield increased by $3.37 \mathrm{~g}$ with each addition of 1g Met (Pisulewski et al., 1996). The results in these studies indicate that Met is more limiting than Lys. Another study found that, milk protein yield tended to increase quadratically when adding $0,3.5,7,10.5$ and $16 \mathrm{~g} / \mathrm{d}$ Met to a basal diet that was already supplemented with $10 \mathrm{~g} / \mathrm{d}$ 
Lys. Protein yields were greatest when adding either 0 or $16 \mathrm{~g} / \mathrm{d}$ Met (Socha et al., 2008). The mechanism behind this is still unknown. It is reasonable to assume that enhanced elevation in milk protein production was the result of the Met being utilized by the mammary gland over other tissues and organs in early-lactation period. According to Socha et al. (2008), the greatest responses to supplemental Met and Lys occurs in the earliest stages of lactation when the demand for absorbed AA is relatively high compared to absorbed energy. Also, supplementation of Met (16 g/d) and Lys (10 g/d) increased milk protein yield by 7\% from 10 to 50 DIM (Socha et al., 2008).

Treatments had no effect on milk fat percentage $(P=0.16)$ and fat yield $(P=0.72)$ (Table 4-2). The average milk fat percentage and fat yield across treatments were $4.08 \%$ and $1.09 \mathrm{~kg} / \mathrm{d}$ in this experiment (Table 4-2). These responses were confirmed by many similar studies in earlylactation and mid-lactation cows (Socha et al., 2008; Lee et al., 2012; Pisulewski et al., 1996; Armentano et al., 1997). This may be attributed to the fact that RPAA have low possibility of affecting the activity of microorganisms and ruminal fermentation. Surprisingly, supplementation of RP-Met and Lys showed increased milk fat percentages in a few studies (Kazumasa et al., 2006; Watanabe et al., 2006). The authors offered no explanations for these increases. Pipenbrink et al. (1996) mentioned that amounts of CP in the diet did not affect percentage of milk fat significantly, whereas, adding RPAA to $18.5 \%$ or $16 \% \mathrm{CP}$ diets had an inconsistent effect on milk fat content (Socha et al., 2005). It is well known that RPAA would not affect the milk fat yield and this is verified by various studies (Socha et al., 2008; Lee et al., 2012)

Percentage of lactose and TS, yields of lactose and TS, and MUN were not significantly affected by treatments (Table 4-2). However, MUN in Smartamine M numerically ( $P=0.16)$ 
increased by $0.58 \mathrm{mg} / \mathrm{dL}$ and TS percentage in Novimet numerically decreased $(P=0.17)$ by $0.42 \%$ compared to cows fed control diets (Table 4-2). This kind of increase in MUN was also demonstrated by Donkin et al. (1989) who found total milk N elevated by $10 \%$ with supplementation of Met and Lys to the diet. Broderick et al. (2008) reported that reduced MUN was typically found with decreased CP in diets. Benefiled et al. (2009) found that supplementation with Met as Mepron or Smartamine numerically increased TS\% over the basal diet. This result was inconsistent with the numerical decreased in TS\% when Novimet was supplemented in the current study. Most previous studies related to supplementation of Met and Lys observed no impact on these milk components (Armentano et al., 1997; Kazumasa et al., 2006; Socha et al., 2008; Broderick et al., 2009; Lee et al., 2015).

\section{Amino acids in serum}

Concentration of serum Met in cows fed Smartamine M was significantly higher than other treatments including control, Novimet and Mepron M85 (27.3 vs. 21.2, 22.7, and 23.3 $\mu$ M; $P<0.01$, respectively). Met concentrations in Novimet and Mepron M85 supplemented cows were numerically greater than that in the control diet (Table 4-3). These responses indicate that RP-Met effectively escaped, at least to some extent, ruminal digestion and was able to be absorbed by epithelial cells of the small intestine and be transported in the blood. Donkin et al. (1989) also observed elevated plasma methionine when supplementing Met (15 g/d) and Lys (40 $\mathrm{g} / \mathrm{d}$ ) in the RP form to a basal diet. There were no significant differences in serum lysine among treatments, whereas, serum lysine in Novimet, Smartamine M, and Mepron M85 were numerically greater than cows fed the control diet $(117.4,120.1$, and 117.0 vs. $108.8 \mu \mathrm{M}$ respectively). The possible explanation for the responses was that RP-Lys have the ability to 
escape from rumen and to be digested and absorbed in the small intestine. However, the baseline serum Lys concentration was high and therefore the apparent improvement became small and unobvious. The average Lys concentration $(115.8 \mu \mathrm{M})$ was much higher than the $85 \mu \mathrm{M}$ reported in a similar study (Apelo et al., 2014); probably because of the higher CP level diets in the current study (2\% units higher). The concentration of glutamine in cows supplemented with Smartamine $\mathrm{M}$ and Novimet tended to increase compared to that in the control diet $(P=0.15$ and $P=0.18$, respectively). No treatments effects were found on other AA in the serum. The serum ratio of Lys to Met reflected the difference observed in serum Met with the ratio being significantly $(P=0.01)$ lower for cows fed Smartamine M (Table 4-3). This was caused by a significant difference in Met and non-significant difference in Lys. The ratio Lys: Met might be an indicator to maintain or improve milk protein when addition of RP-Met makes Lys become the first limiting AA (Lara, et al. 2006). This lower ratio that was much closer to optimal (NRC, 2001) in cows fed Smartamine M could result in higher efficiency of AA utilization in the mammary gland.

\section{Conclusion}

Our results demonstrate that supplementing mid-lactation dairy cows with Smartamine M enhances milk protein percentage relative to no Met supplementation. In this study, we did not find any beneficial effect of Mepron M85 and Novimet product on milk production performance. The elevation in milk protein percentage was partly due to an increase in Met available in the blood. Further studies are required to investigate the effects of Met and Lys in milk synthesis of mammary gland. 


\section{Literature Cited}

Apelo, S. A., A. L. Bell, K. Estes, J. Ropelewski, M. J. de Veth, and M. D. Hanigan. 2014. Effects of reduced dietary protein and supplemental rumen-protected essential amino acids on the nitrogen efficiency of dairy cows. J. Dairy Sci. 97:5688-5699.

Armentano, L. E., S. J. Bertics, and G. A. Ducharme. 1997. Response of lactating cows to methionine or methionine plus lysine added to high protein diets based on alfalfa and heated soybeans. J. Dairy Sci. 80:1194-1199.

Badawy, A. B., C. J. Morgan, and J. A. Turner. 2008. Application of the Phenomenex EZ: faast ${ }^{\mathrm{TM}}$ amino acid analysis kit for rapid gas-chromatographic determination of concentrations of plasma tryptophan and its brain uptake competitors. N.A. Acid. 34, no. 4 (2008): 587-596.

Benefield, B. C., R. A. Patton, M. J. Stevenson, and T. R. Overton. 2009. Evaluation of rumenprotected methionine sources and period length on performance of lactating dairy cows within Latin squares. J. Dairy Sci. 92:4448-4455.

Broderick, G. A., M. J. Stevenson, R. A. Patton, N. E. Lobos, and J. J. Olmos Colmenero. 2008. Effect of supplementing rumen-protected methionine on production and nitrogen excretion in lactating dairy cows. J. Dairy Sci. 91:1092-1102.

Deriaz, R. E. 1961. Routine analysis of carbohydrates and lignin in herbage. J. Sci. Food Agric. 12:152-160.

Donkin, S. S., G. A. Varga, T. F. Sweeney, and L. D. Muller. 1989. Rumen-protected methionine and lysine: effects on animal performance, milk protein yield, and physiological measures. J. Dairy Sci. 72:1484-1491.

Lara, A., G. D. Mendoza, L. Landois, R. Barcena, M. T. Sánchez-Torres, R. Rojo, J. Ayala, and S. Vega. 2006. Milk production in Holstein cows supplemented with different levels of ruminally protected methionine. Livest. Sci. 105:105-108.

Lee, C., F. Giallongo, A. N. Hristov, H. Lapierre, T. W. Cassidy, K. S. Heyler, G. A. Varga, and C. Parys. 2015. Effect of dietary protein level and rumen-protected amino acid supplementation on amino acid utilization for milk protein in lactating dairy cows. J. Dairy Sci. 98:1885-1902.

Lee, C., A. N. Hristov, T. W. Cassidy, K. S. Heyler, H. Lapierre, G. A. Varga, M. J. De Veth, R. A. Patton, and C. Parys. 2012. Rumen-protected lysine, methionine, and histidine increase milk protein yield in dairy cows fed a metabolizable protein-deficient diet. J. Dairy Sci. 95:6042-6056.

NRC. 2001. Nutrient Requirements of Dairy Cattle. 7th rev. ed. Natl. Acad. Sci., Washington, DC. 
Patton, R. A. 2010. Effect of rumen-protected methionine on feed intake, milk production, true milk protein concentration, and true milk protein yield, and the factors that influence these effects: A meta-analysis. J. Dairy Sci. 93:2105-2118.

Piepenbrink, M. S., T. R. Overton, and J. H. Clark. 1996. Response of cows fed a low crude protein diet to ruminally protected methionine and lysine. J. Dairy Sci. 79:1638-1646.

Pisulewski, P. M., H. Rulquin, J. L. Peyraud, and R. Verite. 1996. Lactational and systemic responses of dairy cows to postruminal infusions of increasing amounts of methionine. J. Dairy Sci. 79:1781-1791.

Rogers, J. A., U. Krishnamoorthy, and C. J. Sniffen. 1987. Plasma amino acids and milk protein production by cows fed rumen-protected methionine and lysine. J. Dairy Sci. 70:789-798.

Schingoethe, D. J. 1991. Protein quality and amino acid supplementation in dairy cattle. Proceeding of Southwest Nutrition Management Conference; Tempe, Arizona; 1991. 101-106.

Smith, D. 1969. Removing and analyzing total nonstructural carbohydrates from plant tissue. Res.Reports. Wisconsin Coll. Agric. Life Sci. 41.

Socha, M. T., D. E. Putnam, B. D. Garthwaite, N. L. Whitehouse, N. A. Kierstead, C. G. Schwab, G. A. Ducharme, and J. C. Robert. 2005. Improving intestinal amino acid supply of preand postpartum dairy cows with rumen-protected methionine and lysine. J. Dairy Sci. 88:1113-1126.

Socha, M. T., C. G. Schwab, D. E. Putnam, N. L. Whitehouse, B. D. Garthwaite, and G. A. Ducharme. 2008. Extent of Methionine Limitation in Peak-, Early-, and Mid-Lactation Dairy Cows 1, 2. J. Dairy Sci. 91:1996-2010.

Watanabe, K., A. H. Fredeen, P. H. Robinson, W. Chalupa, W. E. Julien, H. Sato, H.Suzuki, K. Katoh, and Y. Obara. 2006. Effects of fat coated rumen bypass lysine and methionine on performance of dairy cows fed a diet deficient in lysine and methionine. Anim. Sci. J. 77:495-502. 
TABLES AND FIGURES

Table 4-1: Ingredients and nutrient composition of the control diet for mid-lactation dairy cows.

\begin{tabular}{|c|c|}
\hline Item & Amount, $\%$ of DM \\
\hline \multicolumn{2}{|l|}{ Ingredient (\% DM) } \\
\hline Corn silage $^{1}$ & 37.10 \\
\hline Alfalfa hay ${ }^{2}$ & 20.61 \\
\hline Dairy pellets ${ }^{3}$ & 11.70 \\
\hline Ground corn & 7.21 \\
\hline Corn gluten meal $60 \%$ & 6.18 \\
\hline Soybean meal, $47.5 \% \mathrm{CP}$, solvent extracted & 8.25 \\
\hline Soybean hull, pelleted & 4.46 \\
\hline Megalac-R & 1.05 \\
\hline Sodium bicarbonate & 1.05 \\
\hline WVU dairy MIN 12101 & 1.03 \\
\hline Fat soybean oil & 0.21 \\
\hline SaltTMin & 0.01 \\
\hline ZarMin & 0.52 \\
\hline ZinproAvaila-Plus & 0.10 \\
\hline VitaminPremixE & 0.52 \\
\hline \multicolumn{2}{|l|}{ Nutrient composition } \\
\hline $\mathrm{DM}, \%$ & 61.6 \\
\hline $\mathrm{CP}, \% \mathrm{DM}$ & 17.7 \\
\hline RUP, \% CP & 42.1 \\
\hline NDF, \% DM & 37.3 \\
\hline Forage NDF, \% DM & 28.5 \\
\hline Starch, \% DM & 22.9 \\
\hline Ether extract, \% DM & 4.3 \\
\hline Ash, \% DM & 12.6 \\
\hline $\mathrm{NE}_{\mathrm{L}}, \mathrm{Mcal} / \mathrm{kg} \mathrm{DM}{ }^{4}$ & 0.34 \\
\hline Met:Lys ${ }^{5}$ & 2.92:1 \\
\hline
\end{tabular}

${ }^{1}$ Contained (DM basis): 39.7\% DM (as fed); 42.9\% NDF; 22.4\% ADF; 46.1\% starch; $2.8 \%$ ash; $2.6 \%$ ether extract.

${ }^{2}$ Nutrient analysis (DM basis: $84.8 \%$ DM (as fed); $42.5 \%$ NDF; 31.7\% ADF; 3.1\% starch; 9.7\% ash; $1.3 \%$ ether extract.

${ }^{3}$ Contained (DM basis):88.4\% DM (as-feed); $24.98 \%$ CP; 7.22\%; $28.60 \%$ NDF; $19.42 \%$ ADF; $39.85 \%$ NFC; $30.94 \%$ Starch.

${ }^{4}$ Based on tabular values.

${ }^{5}$ Ratio obtained after supplementing RP-Met and Lys. 
Table 4-2: Dry matter intakes and production responses to rumen protected methionine and lysine supplementation.

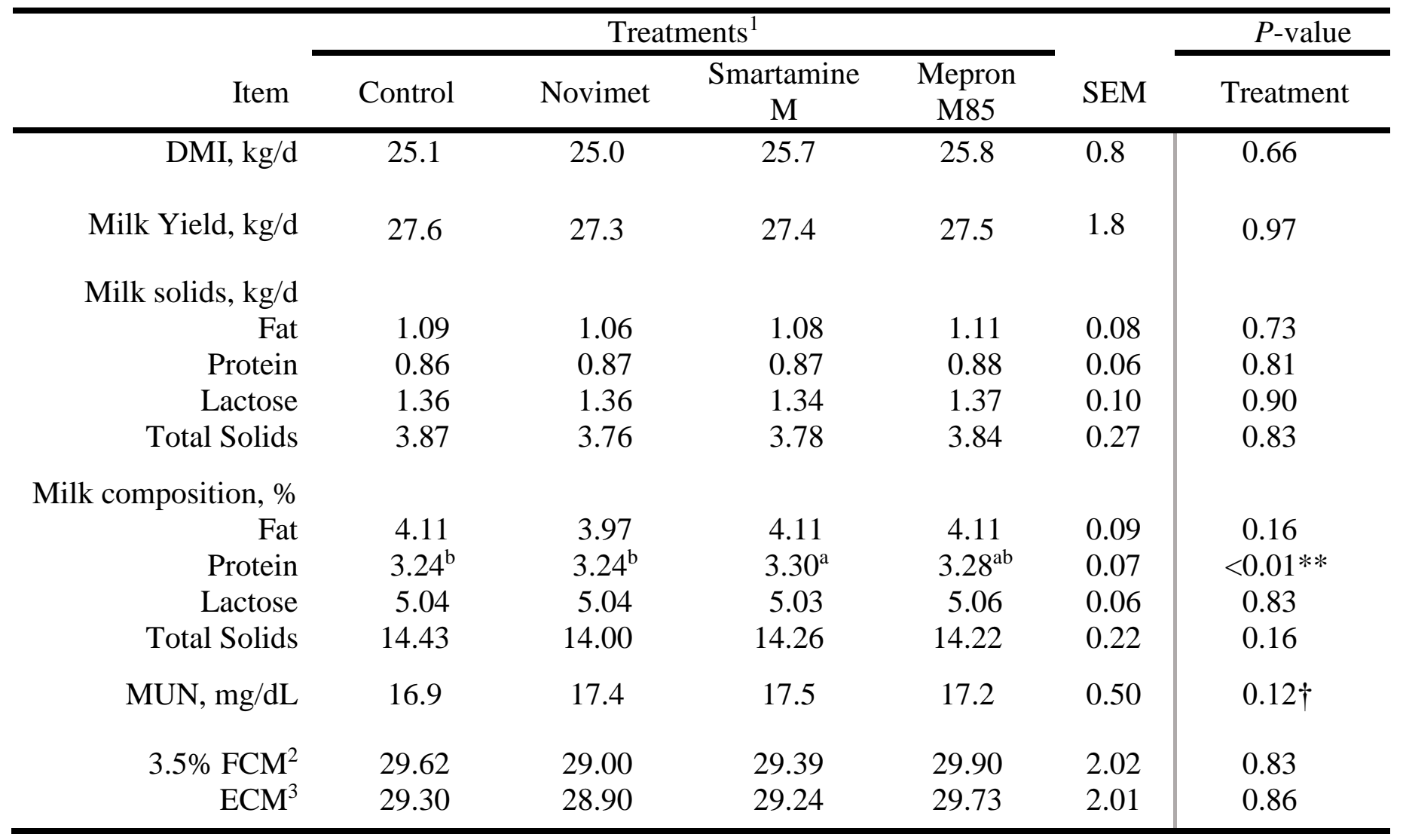

Values are presented as LS Means \pm SEM. $* *, P<0.01 ; *, P<0.05 ; \dagger, P<0.15$.

${ }^{1}$ Treatments were control (Lys at $0.025 \%$ ration DM), Novimet, Smartamine or Mepron (Met and Lys at $0.03 \%$ and $0.20 \%$ ration DM respectively).

$23.5 \% \mathrm{~kg} \mathrm{FCM}=(0.4324 \mathrm{x} \mathrm{kg}$ of milk $)+(16.216 \mathrm{x} \mathrm{kg}$ of milk fat $)$.

${ }^{3} \mathrm{ECM}(\mathrm{kg})=(0.327 \mathrm{x} \mathrm{kg}$ of milk $)+(12.95 \mathrm{x} \mathrm{kg}$ of milk fat $)+(7.2 \times \mathrm{kg}$ of milk fat $)$. 
Table 4-3: Serum amino acids concentrations responses to rumen protected methionine and lysine supplementation.

\begin{tabular}{|c|c|c|c|c|c|c|}
\hline \multirow[b]{2}{*}{ Item } & \multicolumn{4}{|c|}{ Treatments $^{1}$} & \multirow[b]{2}{*}{ SEM } & \multirow{2}{*}{$\frac{P \text {-value }}{\text { Treatment }}$} \\
\hline & Control & Novimet & $\begin{array}{c}\text { Smartamine } \\
\mathrm{M}\end{array}$ & Mepron M85 & & \\
\hline \multicolumn{7}{|l|}{ EAA } \\
\hline His & 56.1 & 56.7 & 56.3 & 55.4 & 7.4 & 0.91 \\
\hline Ile & 156.9 & 157.2 & 163.7 & 159.2 & 4.8 & 0.55 \\
\hline Leu & 248.2 & 243.8 & 249.7 & 250.3 & 7.1 & 0.86 \\
\hline Lys & 108.8 & 117.4 & 120.1 & 117.0 & 6.4 & 0.38 \\
\hline Met & $21.2^{b}$ & $22.7^{b}$ & $27.3^{\mathrm{a}}$ & $23.3^{b}$ & 0.94 & $<0.01 * *$ \\
\hline Phe & 58.7 & 58.3 & 59.5 & 57.6 & 1.8 & 0.80 \\
\hline Thr & 75.3 & 79.3 & 77.9 & 78.9 & 3.4 & 0.80 \\
\hline Trp & 41.2 & 41.0 & 40.4 & 40.5 & 1.3 & 0.94 \\
\hline Val & 311.1 & 295.1 & 309.2 & 300.0 & 10.4 & 0.61 \\
\hline Total EAA & 850.0 & 755.6 & 786.0 & 778.8 & 36.7 & 0.29 \\
\hline Lys:Met ${ }^{3}$ & $5.2^{\mathrm{b}}$ & $5.2^{\mathrm{b}}$ & $4.5^{\mathrm{a}}$ & $5.0^{\mathrm{b}}$ & 0.22 & $0.01 *$ \\
\hline \multicolumn{7}{|l|}{ NEAA } \\
\hline Ala & 211.9 & 210.7 & 221.4 & 206.7 & 6.9 & 0.27 \\
\hline Asn & 45.9 & 48.2 & 49.3 & 48.8 & 2.0 & 0.56 \\
\hline Asp & 8.0 & 8.9 & 8.0 & 8.0 & 0.35 & 0.15 \\
\hline Gln & 289.5 & 319.8 & 320.8 & 305.6 & 7.2 & $0.09 \dagger$ \\
\hline Glu & 67.0 & 69.0 & 61.8 & 66.3 & 3.8 & 0.60 \\
\hline Gly & 192.3 & 194.3 & 190.9 & 182.0 & 6.2 & 0.41 \\
\hline Pro & 94.2 & 93.7 & 93.5 & 97.4 & 4.4 & 0.69 \\
\hline Ser & 69.3 & 71.6 & 71.2 & 69.9 & 3.3 & 0.93 \\
\hline Tyr & 61.8 & 60.3 & 61.4 & 62.0 & 3.1 & 0.95 \\
\hline Total NEAA & 1197.8 & 1158.4 & 1165.0 & 1169.3 & 40.3 & 0.73 \\
\hline Total AA & 2047.9 & 1914.0 & 1950.9 & 1915.3 & 66.4 & 0.31 \\
\hline
\end{tabular}

Values are presented as LS Means \pm SEM; Unit is $\mu \mathrm{m} ; * *, P<0.01 ; *, P<0.05 ; \dagger, P<0.15$.

${ }^{1}$ Treatments were control (Lys at $0.025 \%$ ration DM), Novimet, Smartamine or Mepron (Met and Lys at 0.03\% and 0.20\% ration DM respectively. 


\section{Chapter 5}

\section{GENERAL CONCLUSIONS}

With these two studies in the thesis, the effects of rumen protected (RP) methionine (Met), choline, and betaine on dairy cows milk production performance and health have been investigated. The limited improvements may be due to the over-production of products, short supplementation length, low doses of micronutrients, and specific characteristics of dairy cows used in our studies. However, these experiments provide us a relatively complete insight into understanding physiology in periparturient dairy cows and are references for further research in this area. In our experiments, we analyzed 920 molecular lipid species by using liquid chromatography mass spectrometry (LC/MS). In the future, our lab will use bioinformatics to analyze this large data set and study the possible biomarkers to predict fatty liver in dairy cows. Furthermore, the digestibility of micronutrients in the rumen and intestinal availability are needed to test for further understanding the current results. 